$10-2019$

\title{
Disguised Patent Policymaking
}

Saurabh Vishnubhakat

Texas A\&M University School of Law, sv10@law.tamu.edu

Follow this and additional works at: https://scholarship.law.tamu.edu/facscholar

Part of the Administrative Law Commons, and the Intellectual Property Law Commons

\section{Recommended Citation}

Saurabh Vishnubhakat, Disguised Patent Policymaking, 76 Wash. \& Lee L. Rev. 1667 (2019).

Available at: https://scholarship.law.tamu.edu/facscholar/1376

This Article is brought to you for free and open access by Texas A\&M Law Scholarship. It has been accepted for inclusion in Faculty Scholarship by an authorized administrator of Texas A\&M Law Scholarship. For more information, please contact aretteen@law.tamu.edu. 


\title{
Disguised Patent Policymaking
}

\author{
Saurabh Vishnubhakat*
}

\begin{abstract}
Patent Office power has grown immensely in this decade, and the agency is wielding its power in predictably troubling ways. Like other agencies, it injects politics into its decisions while relying on technocratic justifications. It also reads grants of authority expansively to aggrandize its power, especially to the detriment of judicial checks on agency action. However, this story of Patent Office ascendancy differs from that of other agencies in two important respects. One is that the U.S. patent system still remains primarily a means for allocating property rights, not a comprehensive regime of industrial regulation. Thus, the Patent Office cannot yet claim broad autonomy to make substantive political judgments. Indeed, the agency until now has wielded its power mostly in disguise. The other difference is that the era of broad Patent Office power is still in relative infancy. Recent years have seen important analytical and empirical studies of the agency's dramatic changes, but its new and controversial practices are not yet entrenched. Meaningful reform is still possible, and it is desirable. Patent Office power has grown so much so quickly in part because the political valence of that power has been obscured

* Professor, Texas A\&M University School of Law; Professor, Texas A\&M University Dwight Look College of Engineering; Fellow, Duke Law Center for Innovation Policy. The author was formerly an expert advisor at the United States Patent and Trademark Office. The arguments in this writing are the author's and should not be imputed to the USPTO or to any other organization. Sincere thanks to Kent Barnett, Emily Bremer, Greg Dolin, John Duffy, Randy Gordon, Stuart Graham, Dmitry Karshtedt, Sapna Kumar, Ron Levin, Glynn Lunney, Adam Mossoff, Arti Rai, Lynne Rambo, Michael Risch, Chris Seaman, Chris Walker, Melissa Wasserman, and Peter Yu for helpful comments. Earlier versions of this paper were presented at the Washington and Lee University School of Law, the 2018 AALS Annual Meeting Program on New Voices in Administrative Law, the George Mason University Conference on Perspectives on the PTAB, the University of New Hampshire IP Scholars Roundtable, the Opening Plenary Session of the 2018 Works in Progress IP Colloquium, and the 2017 Intellectual Property Scholars Conference.
\end{abstract}


by a blinkered focus on technological expertise. Understanding the agency's pernicious structural choices-such as commingling separately delegated powers in order to evade judicial review and stacking adjudicatory panels to reach desired outcomes-in terms of politicization reveals significant risks of injury upon the agency's ability to make credible commitments, and also illuminates potential solutions.

\section{Table of Contents}

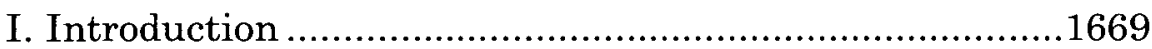

II. Agency Aggrandizement in Patent Law.........................1676

A. Stacking Administrative Judge Panels ...................1676

B. Resisting Review of Case Selection..........................1685

C. Resisting Review of Statutory Boundaries ...............1692

D. Resisting Review of Adjudicatory Obligations ..........1698

III. Effects of Aggrandized Agency Power.............................1705

A. Resulting Agency Benefits ...................................1705

1. Cheuron Deference from Panel Stacking ............1706

2. Autonomy from the Courts Without Cheuron .....1712

B. Resulting Systemic Harms....................................1715

1. Injury to Due Process ......................................1715

2. Injury to Stable Patent Property Rights .............1721

3. Injury to Credible Commitments .......................1726

4. Injury to Future Oversight..............................1731

C. Alternatives to Judicial Review ..............................1733

IV. Sources of Agency Aggrandizement ..............................1736

A. The Traditional Account: Expertise.........................1737

B. The Neglected Rationale: Political Input.................1741

1. Empowering the Agency's Political Leadership ................................................... 1744

2. Making Technology- and Industry-Specific Policy ..............................................................1746

C. Commingled Powers in the Patent Office................1749

D. Focal Points for Reform .......................................1756

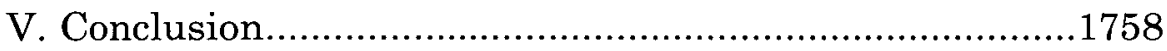

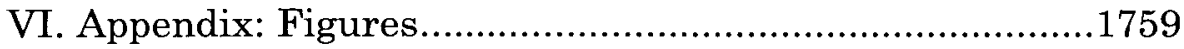




\section{Introduction}

The U.S. Patent and Trademark Office (Patent Office or USPTO) has begun to make policy in disguise, with enough success that the pretense may not be needed much longer. The power of the agency has reached a high-water mark, and although some of the most important and troubling effects of this administrative ascendancy were unintended, they were not unforeseeable. For more than a third of a century, institutional primacy in the patent system lay in the courts, especially the U.S. Court of Appeals for the Federal Circuit. ${ }^{1}$ Over the same period, however, Congress diminished this judicial primacy three times in favor of growing agency power, most recently in the 2011 America Invents Act (AIA). ${ }^{2}$ The relatively benign nature of the first two diminishments, ${ }^{3}$ together with an incomplete understanding of how they relate to the third, explain much about why the agency's power has now started to grow unchecked.

Prior reallocations of power away from the judiciary and to the agency rested on broad legislative consensus. Even in the AIA, the creation of robust agency proceedings by which administrative judges in the USPTO Patent Trial and Appeal Board (PTAB) could revoke previously issued patents rights was a deliberative, if dramatic, choice by Congress. However, the most recent and aggressive expansions of Patent Office power have come from inside the agency itself. Upon receiving specific grants of discretion from Congress, the Patent Office has advanced expansive interpretations of those grants, reflecting ever broader claims of its own power. ${ }^{4}$ At their most extraordinary, these

1. See Melissa F. Wasserman, The Changing Guard of Patent Law: Chevron Deference for the PTO, 54 WM. \& MARY L. REV. 1959, 1962-63 (2013) (noting that the Federal Circuit is perceived to be "the most important expositor of the substantive law of patents in the United States").

2. Leahy-Smith America Invents Act, Pub. L. No. 112-29, 125 Stat. 284 (2011) (codified in scattered sections of 35 U.S.C.).

3. See 35 U.S.C. $\S 302$ (2018) (limiting scope of ex parte review); id. $\S 311$ (b) (limiting scope of inter partes review).

4. See, for example, infra Part II.B, discussing how the PTAB has sought to insulate itself from judicial review after the AIA made the PTAB's discretionary decision whether to review a case "final and nonappealable," 35 
claims include the power to stack panels of administrative judges to reach desired outcomes in individual cases. ${ }^{5}$ The agency has stacked panels in a number of cases and even multiple times within individual cases. ${ }^{6}$ The agency also claims the power to make far-reaching decisions about vested patent rights with absolute immunity from judicial review. ${ }^{7}$ The pattern of aggrandizement in the agency's positions, especially before its supervisors in the Federal Circuit, is unmistakable.

What has been less clear, until now, is why Congressional action in this power transfer has been so one-sided. Historically, the justifications for enlarging Patent Office power and for creating and endowing the Federal Circuit's own considerable power were the same: expertise. ${ }^{8}$ The Federal Circuit was created in 1982 out of a desire for nationally uniform appellate oversight in patent litigation, which had previously been fragmented across regional circuits. ${ }^{9}$ Uniformity would come from a single court

U.S.C. $\$ 314(\mathrm{~d})$ (nonappealability of inter partes review); id. $\S 324(\mathrm{e})$ (nonappealability of post-grant review).

5. See infra Part II.A (discussing the PTAB's recent practice of reconfiguring administrative judge panels with different or additional agency judges to produce outcomes it seeks).

6. For example, in Target Corp. U. Destination Maternity Corp., No. IPR2014-00508 (P.T.A.B. Sept. 25, 2014), the original PTAB panel consisted of three judges but by the end, four judges had been added and all seven judges voted on Target Corporation's Motion for Joinder. See Decision Granting Motion for Joinder, Target, No. IPR2014-00508, Paper 31 (granting joinder by a vote of 4-3).

7. See infra Part II.B-II.D (describing the PTAB's attempts to argue that its case selection, statutory time bar, and adjudication decisions are unreviewable).

8. See Saurabh Vishnubhakat, Arti K. Rai \& Jay P. Kesan, Strategic Decision Making in Dual PTAB and District Court Proceedings, 31 BERKELEY TECH. L.J. 45, 51-55 [hereinafter Strategic Decision Making] (identifying expertise, cost, and accuracy as primary reasons why Congress created a system where patent examinations are reviewed within the Patent Office); 28 U.S.C. $\S 44$ note (2018) (Congressional Statement Regarding Appointment of Judges) ("The Congress ... suggests that the President, in nominating individuals to judgeships on the United States Court of Appeals for the Federal Circuit . . . select from a broad range of qualified individuals.").

9. See H.R. REP. No. 97-312, at 20-23 (1981) ("The new Court of Appeals for the Federal Circuit will provide nationwide uniformity in patent law, will make the rules applied in patent litigation more predictable and will eliminate the expensive, time-consuming and unseemly forum-shopping that characterizes litigation in the field."). The Federal Circuit was created by the Federal Courts Improvement Act of 1982, Pub. L. No. 97-164, 96 Stat. 25 (codified as amended 
with exclusive appellate jurisdiction, populated by judges who were experts in patent doctrine. ${ }^{10}$ Since then, a number of Federal Circuit judges have also brought substantive expertise in science and technology. ${ }^{11}$

Meanwhile, the first grant to the Patent Office of power broadly to reevaluate already-issued patents came in 1981 with the creation of ex parte reexamination. ${ }^{12}$ Power over patent validity previously belonged primarily to Article III courts, but the relatively greater expertise of the Patent Office promised faster, cheaper, and more accurate decisions than those of generalist district judges and juries. ${ }^{13}$ Even more than the Federal Circuit, the agency had clear expertise in the science and technology of the inventions being patented as well as in the doctrinal details of patent law. ${ }^{14}$

in scattered sections of 28 U.S.C.).

10. See Timothy B. Dyk, Does the Supreme Court Still Matter?, 57 AM. U. L. REv. 763, 772 (2008) ("The Supreme Court has repeatedly confirmed that the Federal Circuit has useful expertise in patent law, and that the Supreme Court benefits from having its views."). However, judges appointed to the Federal Circuit have not always had patent or trademark law expertise. See Report Concerning the Nomination of Judges to the Court of Appeals for the Federal Circuit, 70 J. PAT. \& TRADEMARK OFF. SoC'Y 599, 603 [hereinafter Report Concerning Nominations] (lamenting the nominations to the Federal Circuit from its creation in 1982 to 1988 because "only one out of the seven nominees submitted to Congress in that period, Judge Newman, had patent expertise").

11. See, e.g., Report Concerning Nominations, supra note 10, at 602 n.9 (describing how Chief Judge Markey's background as a patent lawyer helped the Federal Circuit address and resolve circuit splits on various patent law issues); id. at 603 n.11 (noting that Judge Nies was a trademark lawyer prior to his appointment to the bench but had had two years of patent experience as a judge on the Court of Customs and Patent Appeals).

12. See Act of Dec. 12, 1980, Pub. L. No. 96-517, 94 Stat. 3015 (codified as amended at 35 U.S.C. $\$ \S 301-307$ (2018)) (allowing parties to request reexamination of patent claims based on prior art).

13. See supra note 8 and accompanying text (discussing how reduced costs, expertise, and accuracy associated with Patent Office review influenced Congress in broadening the Patent Office's review powers).

14. Compare 35 U.S.C. $\$ 6$ (2018) (requiring that "administrative patent judges shall be persons of competent legal knowledge and scientific ability"), with 28 U.S.C. $\$ 44$ note (Congressional Statement Regarding Appointment of Judges) (expressing the sense of the Congress merely that "qualified individuals" should be appointed to the Federal Circuit). 
Subsequent enlargements of Patent Office power relied on the same claim of expertise, especially scientific expertise. The system of inter partes reexamination created in the 1999 American Inventors Protection Act ${ }^{15}$ and the suite of trial-like administrative adjudications created in the 2011 America Invents Act all held up the agency's expertise as a reason to empower it further. Indeed, the AIA in particular was explicitly substitutionary in ways that the preceding reexamination systems were not.16 The Patent Office did not only receive broader power, but now received that power at the expense of the courts. In many contexts, parties could choose one forum or the other, but either choice now foreclosed the other. ${ }^{17}$ Patent power became more of a zero-sum game, and expertise was the stated justification.

The blinkered focus on expertise, however, has obscured until now, another important principle that animates the Patent Office's claims to expansive power and does much to explain the agency's behavior, even its initial success. That principle is the direct injection of politics and policy preferences into patent law. The Patent Office has suffered from a well-known history of being denied autonomy in matters of substantive patent law and policy. This history, which includes a lack of Chevron deference ${ }^{18}$ on legal matters and intrusive judicial review even on factual matters, set the agency apart from most of the modern administrative state. ${ }^{19}$ Meanwhile, the transformations that the AIA brought about were a sea change in the systemic role of the

15. See Pub. L. No. 106-113, § 4604, 113 Stat. 1501A-552, 567-70 (codified as amended in 35 U.S.C. $\S \S 311-319$ ) (allowing for inter partes review of patent claims and setting forth procedures for such review).

16. See, e.g., 35 U.S.C. $\S 325$ (d) (allowing the Director of the Patent Office to prioritize a post-grant review while, among other things, staying or terminating other pending proceedings regarding the same patent).

17. See id. $\$ 325$ (a) (barring post-grant review by the Patent Office if the requesting party has already filed a civil action in the courts).

18. See Chevron, U.S.A., Inc. v. Nat. Res. Def. Council, Inc., 467 U.S. 837, 842-44 (1984) (discussing the deference given by courts to "permissible constructions" by agencies of ambiguous statutes governing their actions).

19. See Wasserman, supra note 1, at 1973 (noting that Chevron deference is warranted when an agency has "authority to engage in formal adjudication or rule making," but "[u]nlike most notable agencies, the PTO lacks significant substantive rule-making authority"). 
Patent Office. Legislative and academic opinion were focused on agency expertise, ${ }^{20}$ with no corresponding political account of agency power to impose principled limits, creating the opportunity for a clean break from past practice.

The effects of this break are profound. The Patent Office stands to make considerable institutional gains from its aggrandizements. Foremost among these gains is the freedom to engage in structural and, eventually, substantive policymaking with little or no judicial competition from district courts or supervision from the Federal Circuit. ${ }^{21}$ Indeed, the initial balance in this power struggle is mixed but presently tips in the agency's favor. At the same time, recent Patent Office practices inflict significant injury to stable property rights in the patent system, to the ability of Congress and of the agency itself to make credible commitments to innovators and consumers, and to the future of judicial safeguards in the patent system. ${ }^{22}$ If realized, the gains may be short-lived or not, but the injuries are likely to be long-lasting.

To be sure, one may reasonably ask what is so fundamentally troubling about an administrative agency exercising political

20. For illustrative legislative discussion, see, for example, 157 CONG. REC. 2,843 (2011) (statement of Sen. Klobuchar) (praising the ALA's provisions allowing any third party to provide patent examiners with potentially relevant information because they could enhance the agency's expertise); Crossing the Finish Line on Patent Reform: What Can and Should Be Done: Hearing Before the Subcomm. on Intellectual Prop., Competition, and the Internet of the $H$. Comm. on the Judiciary, 112th Cong. 15 (2011) (statement of David Simon, Associate General Counsel, Intel Corporation) (arguing that no limitations should be placed on the inter partes and ex parte review systems because limitations "will encourage immediate lawsuits on bad patents to avoid the expertise of the Office invalidating these patents"). For illustrative academic discussion, see Wasserman, supra note 1, at 1985 (lamenting that the D.C. Circuit has deferred to the expertise of the Patent Office instead of seizing on ambiguity to review agency proceedings); Ryan Whalen, Complex Innovation and the Patent Office, 17 CHI.-Kent J. InTELL. Prop. 226, 262-64 (2017) (suggesting reforms to improve Patent Office efficiency, like opening up inter partes review by providing incentives that maximize the expertise of patent examiners).

21. See infra Part II.B (discussing how the Patent Office's decision to institute review of patents is final and nonappealable).

22. See infra Part III.B (discussing the systemic harms caused by aggrandized agency power). 
power and making policy in its own domain. Even the tendency of agencies to aggrandize their power is well-theorized and easy to identify precisely because this tendency is widespread. Why is Patent Office power different?

For one thing, it is unlike decades-old regimes such as securities regulation or telecommunications that, at times, also present concerns of unchecked agency power. The revocation of patent rights through administrative trial proceedings under the AIA is only a few years old. ${ }^{23}$ The system's current scale was much larger than predicted, its eventual scale still unknown, and its eventual reach still untested. For scholars and institutional designers who have been present at the creation, therefore, the best time to curb Patent Office aggrandizement is now, after detailed empirical information about the system and its effects has become available ${ }^{24}$ - but before its more dubious precedents become too strongly entrenched to reverse.

The other, more fundamental difference is that the Patent Office's disempowered past is also its present. Though the agency may wish to move away from its past subordination to the Federal Circuit, Congress has made no such move. Patent law historically denied the Patent Office substantive rulemaking authority and the judicial deference that comes with it. ${ }^{25}$ Congress considered proposals to change this in the AIA, but rejected them. ${ }^{26}$ Congress could have committed more of the

23. The AIA was enacted on September 16, 2011 but it took effect one year later. Leahy-Smith America Invents Act, Pub. L. No. 112-29, § 35, 125 Stat. 284, 341 (2011).

24. See generally Brian J. Love \& Shawn Ambwani, Inter Partes Review: An Early Look at the Numbers, 81 U. CHI. L. REV. DiALOGUE 93 (2014) (reporting an empirical study tracking the outcome of IPR proceedings two years after the effective date of the AIA); Matthew R. Frontz, Staying Litigation Pending Inter Partes Review and Effects on Patent Litigation, 24 FED. CIR. B.J. 469 (2015) (discussing empirical data showing the effects of IPR on parallel federal court litigation); Strategic Decision Making, supra note 8 (presenting an empirical and analytical study of how litigants use IPR relative to parallel federal court litigation).

25. See Wasserman, supra note 1, at 1973 ("The PTO, however, has not historically possessed the authority to engage in formal adjudication or rule making-the two formal procedures that Mead indicates would likely warrant deference." (citing United States v. Mead Corp., 533 U.S. 218, 229-31 (2001)).

26. See 153 ConG. REC. H10,281 (daily ed. Sept. 7, 2007) (statement of CONNECT) ("The existing rulemaking language in the bill is too expansive and gives the [Patent Office] unparalleled authority.... As such, we urge you to 
administrative trial process to the agency's discretion, but did not do so. What politically inflected powers the Patent Office did receive were specific and more limited than how it actually exercises those powers. For the agency now to try and squeeze elephants into these mouseholes is inappropriate.

Given these likely systemic injuries and the unpersuasive counter-arguments that support the Patent Office's conduct, a political explanation and evaluation of agency power that goes beyond expertise alone is necessary. This Article provides that explanation and evaluation, offering the first detailed critique of recent Patent Office aggrandizements to make policy in disguise.

Part 0 details the offending practices. First, it traces the agency's startling admissions about stacking administrative panels, inconsistent and shifting justifications for it, and the ways in which panel stacking has worked. Then it turns to the agency's attempts to evade judicial review, first by colorably interpreting ambiguous nonappealability statutes and then by relying on early victories to stake out more implausible terrain. Part III evaluates the effects of these practices, identifying particular agency benefits as well as systemic harms. It also explores alternatives to judicial review for policing Patent Office excesses and concludes that these alternatives are ultimately inadequate.

Building on these descriptive and normative premises, Part IV then explains how the Patent Office was able to engage in these successful and attempted expansions of its own power. It begins with the traditional account of expertise as the reason why power over patent validity should be reallocated from courts to the agency, finding this account incomplete. It continues with a discussion of politics and policy preferences as an increasingly salient explanation for Patent Office power, including even legislative indications that these values should, within limits, play a role in patent law. It turns next to a discussion of the

follow the Senate's lead and remove the PTO rulemaking provision from the House bill."); id. at H23,958 (statement of Rep. Issa) ("But this amendment on rulemaking which would stop an arbitrary decision by the Patent Office on something it may want to do ... is there for a reason. ... [I]t is crucial for this amendment to get into it if we are going to protect against arbitrary action by the Patent and Trademark Office."). 
agency's especially pernicious choice to commingle the separate powers of screening and adjudication, which Congress delegated separately in the AIA, in a single administrative decision-making body. It concludes with focal points for reforming the current system of disguised patent policymaking so that the validity of patent rights is adjudicated more coherently, and the Patent Office exercises its power in a more principled and accountable way.

\section{Agency Aggrandizement in Patent Law}

This Part discusses the two principal ways in which the Patent Office has exercised questionable power in its adjudicatory processes. Both have inappropriately displaced judicial authority, that of the U.S. district courts as well as the Federal Circuit, and both are best understood as political claims to power in the guise of technocratic administration. Part II.A discusses panel stacking, the practice of changing the makeup of certain Patent Office panels of administrative judges to reach desired outcomes. Parts II.B-D discuss a progression of related efforts by the Patent Office to insulate itself from judicial review in the Federal Circuit and from competition with the U.S. district courts for patent validity cases.

\section{A. Stacking Administrative Judge Panels}

The systematic push to enlarge Patent Office power in administrative adjudication, free from judicial interference, is a phenomenon in progress. ${ }^{27}$ The first and most troubling symptom of this enlargement is a pattern of opaquely political Patent Office decision-making. In cases where USPTO leadership has been dissatisfied with an administrative panel's initial decision, the agency's practice has been to reconfigure the panel with additional agency judges and rehear the case to produce a more

27. See Greg Reilly, Bridging the Gap Between the Federal Courts and the Patent \& Trademark Office: The Journal of Science and Technology Law Symposium: The Constitutionality of Administrative Patent Litigation, 23 B.U. J. SCI. \& TECH. 377, 379 (discussing the expansion of the Patent Office's power after Congress passed the America Invents Act). 
desirable outcome. Though the impropriety of changing an adjudicatory tribunal's composition for result-oriented reasons is intuitive, the particular benefits that the agency seems to see for itself through this approach are less obvious, ${ }^{28}$ and the particular systemic harms that result are bound up with the structural details of the agency's patent validity review system. ${ }^{29}$

The Patent Trial and Appeal Board is the Patent Office unit that hears administrative challenges to patent validity, whether inter partes review (IPR), covered business method review, or post-grant review. ${ }^{30}$ These three types of proceedings were established by the AIA to provide a more vigorous reevaluation of the validity of patents that the agency has already issued. ${ }^{31}$ Due to a number of institutional and structural factors, the initial review that patent applications receive from agency examiners tends, in close cases, to err on the side more of granting undeserving patents than of denying deserving ones. ${ }^{32}$

28. See infra Part III.A.1 (discussing the agency's attempts to argue that its authority to stack panels to achieve coherent policy earns it Chevron deference).

29. See infra Part III.B (discussing the harms caused by the Patent Office's aggrandizement of power, including the destabilization of patent property rights).

30. 35 U.S.C. $\S \S 316(c), 326(c)$ (2018).

31. See Strategic Decision Making, supra note 8, at 51 ("The importance of error correction remains a dominant theme in ex post patent review ....").

32. This is the subject of a wide-ranging analytical and empirical literature. For representative discussions of the analytical issues, see generally Sean B. Seymore, The Presumption of Patentability, 97 MinN. L. REv. 990 (2013) (examining the presumption of patentability employed by patent examiners); Jonathan Masur, Patent Inflation, 121 YALE L.J. 470 (2011) (discussing the incentives that the Patent Office has in granting patents because grants cannot be appealed by any party other than the patent applicant); Melissa F. Wasserman, The PTO's Asymmetric Incentives: Pressure to Expand Substantive Patent Law, 72 Oніо ST. L.J. 379 (2011) (arguing that the Federal Circuit is pressured to announce broad legal standards when the Patent Office itself expands patentability standards); Mark A. Lemley, Rational Ignorance at the Patent Office, 95 Nw. U. L. REv. 1495 (2001) (arguing that patent examiners do not thoroughly vet patents in part because of a strain on resource). For representative empirical discussions, see generally Michael D. Frakes \& Melissa F. Wasserman, Does the U.S. Patent and Trademark Office Grant Too Many Bad Patents?: Evidence from a Quasi-Experiment, 67 STAN. L. REv. 613 (2015) (presenting empirical findings that the Patent Office is biased toward granting patents); Michael D. Frakes \& Melissa F. Wasserman, Does Agency Funding 
Meanwhile, correcting patent errors through the federal courts is perceived to be unduly costly, protracted, prone to error, and hard to access due to Article III standing and the declaratory judgment cause of action, among other constraints. ${ }^{33}$ The AIA review proceedings allow these issues to be resolved in adversarial litigation before administrative patent judges who must be "persons of competent legal knowledge and scientific ability" 34 i.e., who must understand both the technological details of patented inventions and the doctrinal details of patent law.

In hearing cases challenging patent validity, the PTAB must sit in panels of "at least 3 members." 35 The Director and Deputy Director of the Patent Office as well as the Commissioners for Patents and Trademarks are, by statute, members of the PTAB in addition to the administrative patent judges themselves. ${ }^{36}$ The power to grant rehearing rests exclusively in the PTAB, and the power to designate members of a PTAB panel belongs to the Director. ${ }^{37}$

Thus, expanding a panel for a rehearing seems, on first impression, to be within the power of the Director, who is a member of the PTAB and is empowered to designate members of a PTAB panel. Yet a series of cases has revealed both the questionable way in which the Patent Office actually exercises these powers and the agency's shifting justifications for its practice. The agency first confirmed its result-oriented panel stacking during a December 2015 oral argument in the Yissum ${ }^{38}$ case:

Affect Decisionmaking?: An Empirical Assessment of the PTO's Granting Patterns, 66 VAND. L. REV. 67 (2013) (presenting empirical findings that suggest the Patent Office's fee structure creates financial incentives for granting patents).

33. See Strategic Decision Making, supra note 8, at 50-64 (summarizing the evolving preference in U.S. patent law for administrative, rather than judicial, error-correction).

34. 35 U.S.C. § 6(a).

35. Id. §6(c) (emphasis added).

36. Id. §6(a).

37. Id. §6(c).

38. Yissum Research Dev. Co. of The Hebrew Univ. of Jerusalem v. Sony Corp., 626 F. App'x 1006 (Fed. Cir. 2015). 
Judge Taranto: And, anytime there has been a seeming other outlier, you've engaged the power to reconfigure the panel so as to get the result you want?

Patent Office: Yes, your Honor.

Judge Taranto: And, you don't see a problem with that?

Patent Office: Your Honor, the Director is trying to ensure that her policy position is being enforced by the panels. ${ }^{39}$

The motivation to implement policy preferences through adjudication rather than through rulemaking is not itself problematic, especially as the Patent Office lacks substantive rulemaking authority. ${ }^{40}$ To the extent that Congress has empowered the agency to "speak with the force of law" 41 through formal adjudicatory authority, incremental policymaking through adjudication may be not only permissible, but preferable. The propriety of doing so by changing a panel's composition, however, is not as clear, as Judge Taranto's subsequent questions in Yissum suggest:

Judge Taranto: The Director is not given adjudicatory authority, right, under $\S 6$ of the statute? That gives it to the Board.

39. Oral Argument at 47:20, Yissum, 626 F. App'x 1006 (Nos. 2015-1342, -1343), https://perma.cc/H3SL-BX5Q (last visited Sept. 2, 2019) (on file with the Washington and Lee Law Review).

40. See Merck \& Co. v. Kessler, 80 F.3d 1543, 1549-50 (Fed. Cir. 1996) (explaining that 35 U.S.C. $\S 6$ (a) "does NOT grant the Commissioner the authority to issue substantive rules").

41. See, e.g., United States v. Vogel Fertilizer Co., 455 U.S. 16, 24 (1982) (quoting Rowan Cos. v. United States, 452 U.S. 247, 253 (1981)). See generally Wasserman, supra note 1 , for an excellent overview of the Patent Office's historical inability to speak with the force of law and the changes that the AIA made in that regard by creating adjudications arguably formal enough to merit judicial deference. 
Patent Office: Right. To clarify, the Director is a member of the Board, but your Honor is correct-

Judge Taranto: But after the panel is chosen, I'm not sure I see the authority there to engage in case-specific re-adjudication from the Director after the panel has been selected.

Patent Office: That's correct, once the panel has been set, it has the adjudicatory authority and the-

Judge Taranto: Until, in your view, it's reset by adding a few members who will come out the other way?

Patent Office: That's correct, your Honor. We believe that's what Alappat holds. ${ }^{42}$

The agency's reliance on the 1994 In re Alappat ${ }^{43}$ decision is notable, as the Patent Office in that case survived a challenge to a similar practice of expanding a panel of the Board of Patent Appeals and Interferences (BPAI). ${ }^{44}$ The BPAI was the predecessor of the PTAB and differed in important ways, making Alappat distinguishable from the present context. The more basic weakness of relying on Alappat, however, is that the Federal Circuit did not actually address the due process challenge in that case, but merely dismissed it as waived. ${ }^{45}$ That the due process concerns associated with panel stacking remain a live issue and raise serious questions about the rule of law became clear during another oral argument, this time in the $\mathrm{Wi}-\mathrm{Fi}$ One $\mathrm{e}^{46}$ case:

42. Oral Argument in Yissum, supra note 39, at 47:41.

43. 33 F.3d 1526 (Fed. Cir. 1994), abrogated by In re Bilski, 545 F.3d 943 (Fed. Cir. 2008).

44. See id. at 1531-36 (holding that the former 35 U.S.C. $§ 7$ (1988) granted the Commissioner of the BPAI the authority to designate the members of a panel and expand a panel).

45. See In re Alappat, 33 F.3d at 1536 (determining that Alappat had waived his due process argument against re-designation of the panel because he acquiesced to the BPAI Commissioner's actions).

46. Wi-Fi One, LLC v. Broadcom Corp., 878 F.3d 1364 (Fed. Cir. 2018). 
Judge Wallach: The situation I described to your esteemed colleague where, in effect, the Director puts his or her thumb on the outcomeshenanigan or not? It's within the written procedures.

Patent Office: So, your hypothetical is the Director stacks the Board?

Judge Wallach: Yeah, more than a hypothetical. It happens all the time. It's a request for reconsideration with a larger panel.

Patent Office: That's within the Director's authority. The makeup of the Board to review the petition is within the Director's authority. Whether that rises to the level of shenanigans or not-

Judge Wallach: Aren't there fundamental rule of law questions there, basic things like predictability and uniformity and transparency of judgments and neutrality of decision makers? And don't we review that kind of thing? ${ }^{47}$

Indeed, these rule of law concerns are of a piece with Federal Circuit unease about other peculiarities in the PTAB's practices, such as selecting certain meritorious portions of petitions for review, denying other portions as being "redundant," and claiming absolute immunity from judicial review or even from explaining the contours of a "doctrine of redundancy." 48 Writing

47. Oral Argument at 26:37, Wi-Fi One, 878 F.3d 1364 (Nos. 2015-1944, -1945, -1946), https://perma.cc/KH7G-Y756 (last visited Sept. 2, 2019) (on file with the Washington and Lee Law Review).

48. See generally Saurabh Vishnubhakat, The Non-Doctrine of Redundancy, 33 BERKELEY TECH. L.J. 777 (2019) (discussing the Patent Office practice of denying requests for review because it believes they are redundant and highlighting problems with this practice). 
separately in Shaw Industries Group, Inc. v. Automated Creel, Systems, Inc., ${ }^{49}$ for example, Judge Reyna concluded in that context that the claim of the Patent Office "to unchecked discretionary authority is unprecedented." 50

The Patent Office then replied more cautiously when pressed about panel stacking during the June 2017 oral argument in the Nidec Motor Corp. v. Zhongshan Broad Ocean Motor Co. ${ }^{51}$ case:

Judge Reyna: What kind of uniformity or certainty do we have in that where the PTAB can look at a prior decision and say, "Well we don't like that, let's jump back in there and change that?"

Patent Office: Well-

Judge Wallach: How does the Director choose which judge to assign to expand the panel?

Patent Office: That's provided, your Honor, by our standard operating procedure. And, the Chief Judge actually makes that decision. And, the judges are selected based on their technical and legal competency. And, over the years, many, many panels at the Board have been expanded. In fact if you looked at the thirty-

Judge Reyna: Are they selected on whether they're going to rule in a certain way?

Patent Office: Well, people can be placed on the panel-for example, the Director can place him- or herself on the panel, and certainly the Director knows how they're going to rule. Nidec has not said - and they say at their blue brief at page 43 that they don't challenge the independence of these judges on

49. 817 F.3d 1293 (Fed. Cir. 2016), abrogated by Wi-Fi One, 878 F.3d 1364 (Fed. Cir. 2018).

50. Shaw Industries Group, 817 F.3d at 1303 (Reyna, J., concurring).

51. 868 F.3d 1013 (Fed. Cir. 2017). 


\begin{abstract}
this panel. These judges were not selected and told to make a particular decision. If judges could be told to make a particular decision, there would be no need to expand a panel in the first place. ${ }^{52}$
\end{abstract}

The agency's assurance of decisional independence for its administrative judges is, indeed, quite important and would do much to reduce concerns about "predictability and uniformity and transparency of judgments and neutrality of decision makers." ${ }^{3}$

However, this account rings hollow in light of the repeated panel stacking in Target Corp. v. Destination Maternity Corp. ${ }^{54}$ In that case, the original panel consisted, as usual, of three judges. ${ }^{55}$ As the decision drew near, the PTAB on its own initiative expanded the panel to five judges to avoid an anticipated unsatisfactory outcome by the three-judge panel. ${ }^{56}$ The PTAB's standard operating procedure for panel stacking provides for exactly this sort of sua sponte expansion. ${ }^{57}$ The panel need not await a request for rehearing: the choice to expand may come before a decision by the current panel. ${ }^{5}$

52. Oral Argument at 25:27, Nidec, 868 F.3d 1013 (No. 2016-2321), https://perma.cc/4Y89-S4RJ (last visited Sept. 2, 2019) (on file with the Washington and Lee Law Review).

53. Oral Argument in Wi-fi One, supra note 47, at 26:37.

54. No. IPR2014-00508 (P.T.A.B. Sept. 25, 2014).

55. See Order on Conduct of the Proceeding, Target, No. IPR2014-00508, Paper 4 (recounting a conference call regarding the briefing schedule between counsel for the parties and the three administrative patent judges assigned to the case).

56. See Decision Denying Motion for Joinder, Target, No. IPR2014-00508, Paper 18 (denying petitioner Target Corporation's motion for joinder by a vote of $3-2)$.

57. See U.S. Patent \& Trademark Office, Patent Trial and Appeal BoARd Standard Operating PROCEDURe 1 (Revision 15) 1-2 (2018), https://perma.cc/74CA-C48R (PDF) ("This [Standard Operating Procedure] does not limit the authority of the Director to designate, de-designate, or otherwise alter in any way at any time, panels ...." (emphasis added)).

58. See id. at 16 ("When an expanded panel is designated (1) after a case initially has been assigned to a panel and (2) before a decision is entered by the panel, the judges initially designated shall be designated, if available, as part of the expanded panel."). 
But in Target, the plan failed at first. Even the expanded five-judge panel reached what the agency leadership considered the wrong outcome.59 The only way this could have happened, of course, was that all three judges originally on the panel had been planning to rule this way in light of the evidence and argument. Indeed, this is just what happened. The PTAB added two judges to the panel, apparently hoping to sway one of the original three and thus produce a 3-2 decision going the other way. None of the three were swayed, however, and the result was a 3-2 decision that frustrated the agency's first, preemptive attempt at panel stacking. ${ }^{60}$

Granting rehearing over the objection of the three original judges, ${ }^{61}$ the PTAB added yet another two judges to the panel, for a total of seven, so that a 4-3 decision that was satisfactory to the agency leadership could be assured. ${ }^{62}$ Even then, the three judges on the original panel, finally outnumbered, still issued a dissent adhering to their original position ${ }^{63}$ just as they had dissented from the re-stacked panel's order granting rehearing at all. ${ }^{64}$

The sum of these illustrations of Patent Office panel stacking is that the ostensibly neutral and independent adjudicatory process that the AIA put in place has been overlaid with a system of adjustments and distortions that are much more outcome-driven in nature and much more beholden to the agency's political hierarchy than a narrative of impartial technocracy might suggest. What the Patent Office might stand to gain from panel stacking-notably, but not exclusively, Chevron deference-is discussed below, ${ }^{65}$ as are the systemic

59. Decision Denying Joinder, supra note 56.

60. Id.

61. See Decision Granting Petitioner's Request for Rehearing, Target, No. IPR2014-00508, Paper 28 (granting rehearing-with the original three judges dissenting).

62. Decision Granting Joinder, supra note 56.

63. See id. at 7 (dissenting opinion) (arguing briefly that 35 U.S.C. $§ 315$ (c) (2018) does not authorize joinder of proceedings and citing their dissenting opinion in Paper 28).

64. See Decision Granting Rehearing, supra note 61, at 1 (dissenting opinion) (arguing that the majority essentially "convert[ed] a statutory bar to inter partes review into a discretionary bar" not subject to review).

65. See infra Part III.A (discussing how the PTAB has sought Cheuron deference by arguing that its panel stacking authority is evidence that it has the 
costs that the practice might impose ${ }^{66}$ and the analytical reasons why the agency might plausibly think itself authorized to decide cases this way at all. ${ }^{67}$ The more immediate lesson is that the details of panel stacking reveal an admitted pattern of Patent Office policymaking in the guise of adjudication, and a desire to implement political judgments using a process built on the rhetoric of the agency's technical expertise.

\section{B. Resisting Review of Case Selection}

Panel stacking reflects an enlargement of Patent Office power that has unfolded primarily inside the agency (though later implications like Chevron deference do look outward to the judiciary). At the same time, the Patent Office has also directly aggrandized itself in the courts, on the issue of judicial review itself, through a series of procedural choices that push beyond the text and structure of the AIA. The Supreme Court approved one of these choices in 2016, as this Part discusses. ${ }^{68}$ The en banc Federal Circuit disapproved a second in early 2018, as Part II.C explains next.69 The third and most recent just failed in the Supreme Court, creating considerable disruption in PTAB administration, as Part II.D addresses. ${ }^{70}$ These attempted aggrandizements mark a significant shift away from the courtagency allocation of power that Congress put in place through the AIA.

power to speak consistently).

66. See infra Part III.B (arguing that panel stacking hurts due process, undermines stability of patent property rights, and prevents meaningful judicial oversight).

67. See infra Part IV (discussing how the PTAB interpreted congressional delegations of power overbroadly).

68. See Cuozzo Speed Techs., LLC v. Lee, 136 S. Ct. 2131, 2136 (2016) (concluding that 35 U.S.C. $\S 314$ (d) bars judicial review of the PTAB's decision to institute IPR).

69. See Wi-Fi One, LLC v. Broadcom Corp., 878 F.3d 1364 (Fed. Cir. 2018) (concluding that time-bar determinations under 35 U.S.C. $\S 315(\mathrm{~b})$ are appealable).

70. See SAS Inst., Inc. v. Iancu, 138 S. Ct. 1348 (2018) (holding that partial institution of inter partes review (e.g., reviewing some claims while not reviewing others) is outside the PTAB's authority). 
The first of the Patent Office's efforts at insulating itself from judicial scrutiny of PTAB review was in the context of evaluating PTAB petitions for merit and deciding whether even to proceed with review. This was a natural starting point because the AIA itself gives the Patent Office some discretion to screen cases and, importantly, makes those discretionary determinations "final and nonappealable." 71 The eventual dispute on this issue would turn on the scope and extent of this discretion and of the insulation of screening-related decisions from judicial review.

In the early days of AIA reviews, particularly inter partes review, the PTAB quickly received a reputation for allowing a large majority of petitions to proceed through the screening phase and into merits adjudication. ${ }^{72}$ Among petitions for inter partes review, the PTAB granted review as to at least one challenged claim in the patent for eighty-four percent of petitions. ${ }^{73}$ Among those petitions that the PTAB selected, the eventual rate of patent cancellation was also quite high: one early estimate found that in seventy-seven percent of cases that reached a final decision on the merits, all of the disputed claims in the patent were invalidated..$^{74}$

71. 35 U.S.C. $§ 314(\mathrm{~d})$ (nonappealability of inter partes review); id. $§ 324(\mathrm{e})$ (nonappealability of post-grant review).

72. See, e.g., R. David Donoghue, 3 Benefits of Parallel District Court Litigation and IPR, LAW360 (June 9, 2014, 10:21 AM), https://perma.cc/2KEX-VL8Q (last visited Sept. 22, 2019) (noting that, as of early 2014, approximately eighty-four percent of inter partes review petitions were instituted) (on file with the Washington and Lee Law Review); Tony Dutra, Rader Regrets CLS Bank Impasse, Comments on Latest Patent Reform Bill, BNA PAT., TRademark \& Copyrigh' L. DAily (Oct. 29, 2013), https://perma.cc/4H96QWFR (last visited Sept. 22, 2019) (recounting the opinion of former Federal Circuit Chief Judge Rader that PTAB judges are "acting as death squads, killing property rights") (on file with the Washington and Lee Law Review); Claims Can Survive Inter Partes and Covered Business Method Review (But Few Do), HUNTON ANDREWS KURTH LLP (Apr. 7, 2014), https://perma.cc/W78C-32KV (last visited Sept. 3, 2019) (arguing that the PTAB is "where patent claims go to die") (on file with the Washington and Lee Law Review); Gregory Dolin, Dubious Patent Reform, 56 B.C. L. REv. 881, 926-27 (2015) (arguing that the PTAB makes it "too easy to invalidate a duly issued patent").

73. See Strategic Decision Making, supra note 8, at 78 (citing a study by Love \& Ambwani, supra note 24, at 100).

74. See Love \& Ambwani, supra note 24, at 94 ("Among IPRs that reach a final decision on the merits, all instituted claims are invalidated or disclaimed more than 77 percent of the time...."). 
The latter finding was to be expected. The PTAB's legal criterion for selecting cases is a sufficient likelihood that at least one of the challenged claims of the patent will successfully be invalidated. ${ }^{75}$ Thus, it stands to reason that cases actually selected for review will tend to reflect outcomes in that direction.

The former finding, however-a high rate of acceptance through the screening process itself--was less self-evident. One possibility was that the set of patents that petitioners would initially be expected to challenge in the PTAB were subject to selection effects. ${ }^{76}$ For example, this is true of disputes that parties litigate in court rather than resolve by settlement. ${ }^{77} \mathrm{On}$ this view, the early cohort of patents that petitioners chose to challenge, especially in inter partes review, were low-hanging fruit and unusually vulnerable to invalidation. ${ }^{78}$

Another important source of the PTAB's observed leniency in screening petitions, however, was its lax interpretation of the requirement that a petition must identify each of its challenges with "particularity." ${ }^{9}$ Controversy arose over this interpretation

75. See 35 U.S.C. $\S \S 314(\mathrm{a}), 324(\mathrm{a})$ (2018) (requiring the Director to determine that "there is a reasonable likelihood that the petitioner would prevail with respect to at least 1 of the claims challenged in the petition" before instituting review).

76. See Gregory Dolin \& Irina D. Manta, Taking Patents, 73 Wash. \& LeE L. REv. 719, 756 (2016) (hypothesizing that because patents tested in the PTAB "crucible" are weaker and more likely to be invalidated, "the high percentage of invalidation at the PTAB indicates nothing other than selection bias").

77. See generally George Priest \& Benjamin Klein, The Selection of Disputes for Litigation, 13 J. LEGAL STUD. 1 (1984) (theorizing that the determinants of whether to litigate are solely economic, and demonstrating that, all economic conditions being equal, plaintiffs can expect about a fifty percent rate of success).

78. See Jarrad Wood \& Jonathan R. K. Stroud, Three Hundred Nos: An Empirical Analysis of the First 300+ Denials of Institution for Inter Partes and Covered Business Method Patent Reviews Prior to In re Cuozzo Speed Technologies, LLC, 14 J. Marshall Rev. InTEll. Prop. L. 112, 141-42 (2015) (citing Rob Sterne \& Gene Quinn, PTAB Death Squads: Are All Commercially Viable Patents Invalid?, IPWATCHDOG (Mar. 24, 2014), https://perma.cc/QB2J-3SQN (last visited Sept. 3, 2019) (on file with the Washington and Lee Law Review)) ("As some practitioners conjecture, perhaps the 'low-hanging fruit' of particularly problematic patents may grow scarce in years to come, further depressing these percentages.").

79. See 35 U.S.C. $\S 312($ a)(3) (requiring that a petition must identify, "in writing and with particularity, each claim challenged, the grounds on which the 
because the Patent Office did not merely claim the power to screen and select cases without judicial interference at the time of screening. Rather, the agency argued that its screening was not subject to judicial supervision at any time, even after a final agency action. ${ }^{80}$ Two competing views arose about the propriety of this interpretation.

One view was that the nonappealability of the decision whether to institute review meant merely that a litigant, particularly an aggrieved patent owner who was being drawn into a review proceeding, could not obtain an interlocutory appeal of the agency's decision to proceed.81 In other words, a patent owner's right not to be subjected to an unmeritorious patent validity challenge was not protected by the courts. Indeed, if such a "right not to stand trial" existed, then by definition it would have to be redressed up front through interlocutory review or not at all.

However, review would remain available later of all issues, on the basic administrative law principle that intermediate issues merge into an agency's final order on the merits. ${ }^{82}$ This would include review of screening-related decisions that may have overlapped analytically with the adjudication of merits or that may have implicated statutory limits on the agency's authority. ${ }^{83}$

challenge to each claim is based, and the evidence that supports the grounds for the challenge to each claim" (emphasis added)).

80. See Brief for the Respondent in Opposition at 6, Cuozzo Speed Techs., LLC v. Lee, 136 S. Ct. 2131 (2016) (No. 15-446), 2015 WL 8621635, at *6 (arguing that "because $\S 314(\mathrm{~d})$ is unnecessary to limit interlocutory appeals, it must be read to bar review of all institution decisions, even after the Board issues a final decision.").

81. See In re Cuozzo Speed Techs., LLC, 793 F.3d 1268, 1291 (Fed. Cir. 2015) (Newman, J., dissenting) ("The stated purpose of the 'final and nonappealable' provision is to control interlocutory delay and harassing filings."); Brief for the Petitioner at 46, Cuozzo, 136 S. Ct. 2131 (No. 15-446), 2016 WL 737452 , at *46. A petitioner to whom the PTAB had denied review was, of course, similarly unable to appeal the unfavorable decision, but strictly speaking, such a review would not have been interlocutory; the decision not to proceed would have been a final agency action otherwise subject to judicial review.

82. See FTC v. Standard Oil Co. of Cal., 449 U.S. 232, 246 (1980) ("[T]he issuance of the complaint averring reason to believe is a step toward, and will merge in, the Commission's decision on the merits.").

83. See Brief for the Petitioner, Cuozzo, supra note 81, at $46-48$ (discussing the justifications for the types of issues that may be subject to reviewability). 
For a petitioner who was incorrectly denied review, meanwhile, there would be no distinction between interlocutory or final judgment review. ${ }^{84}$ The PTAB decision not to proceed would simply end the case with no appeal. ${ }^{85}$

The other, more expansive view was that the nonappealability of the PTAB's screening decision barred more than just interlocutory review: the screening decision was unreviewable even after a final decision by the PTAB on the merits of the case. ${ }^{86}$ In defending the PTAB's practice, this latter expansive position was the view of agency power that the Patent Office took before the Federal Circuit. ${ }^{87}$ It remained the view of agency power that the Solicitor General, in coordination with the Patent Office, took before the Supreme Court. 88

The upshot of the agency's argument was not only to immunize itself from immediate judicial interference with the PTAB's actual decision to proceed with a review or not. ${ }^{89}$ That much the statute itself unambiguously provided. ${ }^{90}$ The agency's approach also immunized it from judicial scrutiny of additional legal issues related to the screening process, including express statutory limits on the circumstances under which a petition "may be considered" at all by the agency, ${ }^{91}$ like the requirement

84. See id. at 46 ("Once the Board institutes IPR, it invalidates more than four out of every five patent claims that reach a final decision.").

85. See id. at 46 ("In a real sense, the Board's decision whether to institute IPR is the most critical stage of the proceeding.").

86. See In re Cuozzo, 793 F.3d at 1273 (concluding that " $\$ 314(d)$ prohibits review of the decision to institute IPR even after a final decision").

87. See Brief for Intervenor-Director of the United States Patent and Trademark Office at 30-33, In re Cuozzo, 793 F.3d 1268 (No. 2014-1301), 2016 WL 737452, at *26 (taking the position that "[the PTAB's decision], by statute, is 'final and nonappealable,' so [the] Court lacks the jurisdiction to consider it").

88. See Brief for the Respondent at 44-50, Cuozzo, 136 S. Ct. 2131 (No. 15-446), 2016 WL 1165967, at *34 (maintaining a broad view of the agency's discretion over the decision).

89. See 35 U.S.C. $\S 314(d)$ (2018) ("The determination by the Director whether to institute an inter partes review under this section shall be final and nonappealable.").

90. Id.

91. See id. §312(a) (describing the situations in which a petition "may be considered"). 
that such consideration was available "only if" the petition satisfied the particularity requirement. ${ }^{92}$

The Supreme Court in Cuozzo v. Lee ultimately ruled in favor of the Patent Office, concluding that the particularity requirement was merely an ordinary element of the screening of petitions, and its analytical proximity to the screening decision swept this legal question into the ambit of unreviewable agency discretion..$^{93}$ The Court majority in Cuozzo also expressed concern that allowing eventual judicial review over agency enforcement of the particularity requirement would hamper the ability of the Patent Office to "revisit and revise earlier patent grants" efficiently. ${ }^{94}$

Although the Court's concern about efficient reevaluation of patent validity was well founded, it is questionable whether vindicating that concern required the far-reaching outcome in Cuozzo. For example, the more modest view of nonappealability, as a bar on interlocutory review, would also have protected PTAB adjudications from disruptive scrutiny. ${ }^{95}$ The Federal Circuit would not have been able to step in before the PTAB had a chance to conduct its review of the merits in a case. Eventual review of the initial screening decision may, at the margin, have allowed a final agency decision to "be unwound under some minor statutory technicality." ${ }^{6}$ Still, the Court seemed not to appreciate that this sort of problem would likely arise only in early appellate reversals. ${ }^{97}$ The agency would learn quickly_indeed, would be forced to learn quickly-from these unwindings and would conform to its supervising court's precedents.

92. See id. § 312(a)(3) ("[T] particularity, each claim challenged ....") (emphasis added).

93. See Cuozzo Speed Techs., LLC v. Lee, 136 S. Ct. 2131, 2139 (2016) (explaining that "the legal dispute at issue is an ordinary dispute about the application of certain relevant patent statutes concerning the Patent Office's decision to institute inter partes review").

94. See id. at 2139-40 ("[A] contrary holding would undercut one important congressional objective, namely, giving the Patent Office significant power to revisit and revise earlier patent grants.").

95. See id. at 2151 (Alito, J., dissenting) (interpreting the word "nonappealable" narrowly).

96. Id. at 2140.

97. See id. at 2140-42 (discussing the danger that appealability presents for the functioning of the Patent Office). 
Ultimately, the Court's desire not to undercut the important legislative objective of efficient patent validity reevaluation proved too much. By this reasoning, which Justice Alito articulated in dissent, the Court could "do away with judicial review whenever [it thought] that review makes it harder for an agency to carry out important work." 98 Congress did give the Patent Office significant new power to reevaluate patent validity, but also prescribed certain means and proscribed certain others in reaching that objective..$^{99}$

Finally, the Court's conception of the actual relationship between screening and adjudication repays close scrutiny. ${ }^{100}$ In response to the argument that the Patent Office had improperly accepted a petition that was not pled with the necessary particularity, the Court concluded that complaints regarding the quality or adequacy of evidence (i.e., issues related to adjudicating the merits of an argument) "can always be recast as a complaint that the ...presentation was incomplete or misleading" (i.e., recast as issues related to screening the viability of an argument). ${ }^{101}$ In other words, the Court recognized that screening the likely viability of a petition and adjudicating its merits overlap considerably, and the danger of sweeping adjudication-related issues into the domain of screening is real, with the availability of judicial review at stake. 102 However, rather than err prudently on the side of judicial oversight as the presumption of reviewability would counsel, ${ }^{103}$ the Court took otherwise reviewable adjudication-related issues and placed them

98. Id. at 2151 (Alito, J., dissenting).

99. See id. (Alito, J., dissenting) (recounting that "no legislation pursues its purposes at all costs" (citing Rodriguez v. United States, 480 U.S. 522, 525-26 (1987) (per curiam))).

100. See id. at 2140-42 (discussing the relationship between screening and adjudication).

101. Id. at 2142 (citing United States v. Williams, 504 U.S. 36, 54 (1992) (internal quotation marks omitted)).

102. See id. (recognizing that adjudicatory and screening concerns often overlap in issues relating to the review of the Patent Office's determinations).

103. See id. at 2150 (Alito, J., dissenting) ("If a provision can reasonably be read to permit judicial review, it should be."). 
alongside screening-related issues, beyond the ability of courts to discipline. ${ }^{104}$

On its own terms, the Cuozzo opinion reflected potential limits on how much unreviewable discretion the Patent Office actually has. Review may still be available, or not, for appeals that (1) "implicate constitutional questions," (2) "depend on other less closely related statutes," or (3) "present other questions of interpretation that reach, in terms of scope and impact, well beyond [the nonappealability statute]." 105 Still, the practical reach of the Cuozzo decision remains unclear. How analytically separable from the institution decision can a statutory provision be and still be treated as a screening-related issue that the courts cannot review?

\section{Resisting Review of Statutory Boundaries}

The first substantial answer to this question came from a decision of the en banc Federal Circuit about another statutory limit on the power of the Patent Office to reevaluate patent validity. The case, Wi-Fi One, LLC $v$. Broadcom Corp., ${ }^{106}$ pertained to the one-year time limit within which a defendant who is charged in a civil action with infringing a patent must bring a petition for inter partes review of that patent or else forgo agency adjudication entirely. ${ }^{107}$

The one-year time bar at issue in Wi-Fi One was an apt test of how far the Court's logic in Cuozzo could extend in practice. Like the particularity requirement at issue in Cuozzo itself, ${ }^{108}$ the one-year time bar could be understood possibly as a

104. See id. at 2150-53 (Alito, J., dissenting) (describing the ramifications of the Court's rejection of the presumption of reviewability).

105. See id. at 2141 (outlining the instances in which application of the Court's interpretation of the statute is not necessarily warranted).

106. 878 F.3d 1364 (Fed. Cir. 2018) (rehearing en banc).

107. See id. at 1367 ; see also 35 U.S.C. $\S 315$ (b) (2018) ("An inter partes review may not be instituted if the petition requesting the proceeding is filed more than 1 year after the date on which [the party] is served with a complaint alleging infringement of the patent.").

108. See Cuozzo Speed Techs., LLC v. Lee, 136 S. Ct. 2131, 2137 (2016) (highlighting the "applicable patent law requirements" for the purposes of review). 
screening-related issue beyond the reach of judicial review. ${ }^{109} \mathrm{It}$ could also, more properly, be understood as an analytically distinct statutory limit on the agency's power to adjudicate patent validity-power that is, indeed, subject to judicial review. The Federal Circuit's own precedent on the question treated the one-year time bar as unreviewable. ${ }^{110}$ The Patent Office agreed and sought to follow its success in Cuozzo with even broader scope for nonappealability. ${ }^{111}$

The en banc question presented was whether to overrule the governing panel precedent.112 A decisive 9-4 majority did overrule it, holding that the PTAB's application of the one-year time bar is, indeed, subject to judicial review. ${ }^{113}$

The dispute in Wi-Fi One implicated an important distinction between screening PTAB petitions and adjudicating them. ${ }^{114}$ The availability of administrative review in the Patent Office as a substitute for federal-court litigation has direct effects both on individual case outcomes and on the patent system more generally. ${ }^{115}$ It was necessary, therefore, for the Federal Circuit to

109. See Wi-Fi One, 878 F.3d at 1371 (acknowledging the panel's view in holding the time-bar challenges to be unreviewable).

110. See Achates Reference Publ'g, Inc. v. Apple Inc., 803 F.3d 652, 658 (Fed. Cir. 2015) (holding that the statute "prohibits this court from reviewing the Board's determination to initiate IPR proceedings based on its assessment of the time-bar of [the statute]").

111. See Wi-Fi One, 878 F.3d at 1373 (weighing the merits of "the PTO's position that the time-bar determination is unreviewable").

112. See id. at 1367 (asking whether the court should overrule Achates and hold that judicial review is available for a patent owner to challenge the PTO's determination).

113. See id. at 1367 (holding that the time-bar determinations under the statute are appealable, overruling Achates).

114. The arguments summarized in this Part are more fully developed in a related article. See Saurabh Vishnubhakat, The Porous Court-Agency Border in Patent Law, 51 AKRON L. REv. 1069 (2018) [hereinafter Porous Court-Agency Border] (analyzing the "weakening border" between administrative and judicial reviewability) These arguments are also further developed in an amicus curiae brief filed in the Wi-Fi One case itself. See Brief of Amici Curiae Professors of Patent and Administrative Law in Support of Neither Party, Wi-Fi One, 878 F.3d 1364 (Nos. 15-1944, 15-1945, 15-1946) [hereinafter Professors' Amicus Brief in Wi-Fi] (discussing the development of reviewability in the realm of PTAB determinations).

115. See Porous Court-Agency Border, supra note 114, at 1090-92 (discussing the possible ramifications of the Wi-Fi One decision). 
take into account these effects of Patent Office validity reviews because the Court in Cuozzo had emphasized these sorts of functional considerations in deciding whether judicial review is available. ${ }^{116}$ Indeed, the substitution of Patent Office proceedings for the traditional modes of federal court resolution was not merely Congress's intended use for the AIA. ${ }^{117}$ It is also the result actually observed in practice.

Litigants use inter partes review and covered business method review as strategic substitutes for litigation in two important ways. ${ }^{118}$ One is the standard model of substitution, in which a defendant sued in district court for infringing a patent brings a petition in the agency to challenge that patent. ${ }^{119} \mathrm{In}$ contrast to this defensive posture is the nonstandard model of substitution, in which a party brings a preemptive challenge against a patent on which it has not yet been sued. ${ }^{120}$ Litigants use each form of substitution differently, with variation across technology and other factors. ${ }^{121}$ These differences also rest in significant part on statutory boundaries that the AIA drew between courts and the Patent Office. ${ }^{122}$ The one-year time bar of $\S 315(\mathrm{~b})$ is one of the most important of these boundaries, which

116. See Cuozzo, $136 \mathrm{~S}$. Ct. at 2141 (distancing the Court's decision on the issue of particularity from other legal issues based on their potential "scope and impact").

117. See Wi-Fi One, LLC v. Broadcom Corp., 878 F.3d 1364, 1377 (Fed. Cir. 2018) (rehearing en banc) (O'Malley, C.J., concurring) (highlighting that Congress chose to afford patent owners with the "important procedural right" of "judicial review of erroneous determinations by the PTO").

118. See Strategic Decision Making, supra note 8, at 64-77. (noting that litigants use post-grant review in essentially the same ways, to a lesser but growing extent); see also generally Saurabh Vishnubhakat, The Youngest Patent Validity Proceeding: Evaluating Post-Grant Review, 24 TEx. INTELl. Prop. L.J. 333, 335 (2016) [hereinafter Youngest Patent Validity Proceeding] (evaluating the institutional features of "ex post patent validity review in the administrative agency setting of the USPTO").

119. See Strategic Decision Making, supra note 8, at 49 (outlining efficiency as a major normative argument for administrative ex post review).

120. See id. (delineating the two common scenarios in which patent challenges are brought).

121. See id. (surveying the methods that petitions use standard and non-standard substitution).

122. See Porous Court-Agency Border, supra note 114, at 1075 ("By the time of the AIA's enactment, however, Congress was prepared to shape the border between courts and the Patent Office more actively ...."). 
force a choice between seeking administrative review or proceeding in an Article III court. ${ }^{123}$

As to degrees of usage, standard petitioners account for a large majority (seventy percent) of those who seek inter partes review. ${ }^{124}$ Similarly, among all the patents being challenged in PTAB review, a large majority (eighty-seven percent) are also simultaneously being asserted in court litigation. ${ }^{125}$ Meanwhile, the thirty percent of those seeking inter partes review who are nonstandard petitioners nevertheless constitute a substantial minority. ${ }^{126}$ Of particular salience to these different levels of use between standard and nonstandard petitioning is coordination among those who mount administrative patent challenges. ${ }^{127}$ The nature of their coordination reveals that the Patent Office is the locus of significant collective action in a way that courts have long been unable to achieve. ${ }^{128}$

Because a patent invalidation judgment in court renders the patented invention free not only to the successful challenger but to all others, ${ }^{129}$ even those would-be free riders who did not contribute to the challenge, such judgments become a type of public good. ${ }^{130}$ Meanwhile, those who are positioned to mount

123. See id. (discussing the various avenues through which Congress actively engaged in delineating the line between the Patent Office and the courts).

124. See Strategic Decision Making, supra note 8, at 73 ("[T]he majority (70\%) of IPR petitioners have previously been defendants in district court litigations involving the patents they now challenge.").

125. See id. at 69 ("[A]bout $86.8 \%$ of IPR- or CBM-challenged patents are also being litigated in the federal courts.").

126. See id. at 73 (outlining "the remaining $30 \%$ of cases" in which petitioners are not prior defendants).

127. See id. at 74-75 (discussing the possible social and juridical repercussions of "collective action" as a method to challenge invalid patents).

128. See id. (noting the explicit mission of certain organizations to bring collective challenges to patents in the Patent Office).

129. See Blonder-Tongue Labs. v. Univ. of Ill. Found., 402 U.S. 313, 350 (1971) (stating that res judicata and collateral estoppel are affirmative defenses available to be plead in patent claims).

130. See Joseph Scott Miller, Building a Better Bounty: Litigation-Stage Rewards for Defeating Patents, 19 BERKELEY TECH. L.J. 667, 687-88 (2004) (assessing the aftermath of the Blonder-Tongue holding and the possibility that the rule "turns patent invalidity judgements into public goods"). 
court challenges to patent validity at all must satisfy stringent Article III standing requirements. ${ }^{131}$ Their "particularized stake" in the patent, on which their standing to sue rests, is often of a piece with their incentives to appropriate the full value of their investments in litigation, and tend to exclude those would-be challengers who might raise patent challenges in what they see as the broader public interest. ${ }^{132}$ A single challenger or a small group of challengers is unlikely ever to fully capture the value of its successful judicial decree of patent validity, and economic theory suggests that collective action against questionable patents will likely be undersupplied. ${ }^{133}$ By allowing Patent Office validity challenges with no standing requirement, the AIA has lowered the entry cost of engaging in this sort of collective action. ${ }^{134}$

The way in which this collective action in Patent Office proceedings actually plays out is through the PTAB's joinder rules, which authorize the Director to consolidate into a single case any other party that has properly filed a petition of its own warranting review. ${ }^{135}$ Across the population of inter partes reviews generally and especially in certain technology areas, there is considerable joinder among standard and nonstandard

131. See MedImmune, Inc. v. Genentech, Inc., 549 U.S. 118, 127 (2007) (summarizing that plaintiffs seeking a declaratory judgment on patent validity must show that there is "a substantial controversy, between parties having adverse legal interests, of sufficient immediacy and reality to warrant the issuance of a declaratory judgement").

132. See Michael J. Burstein, Rethinking Standing in Patent Challenges, 83 GEO. WASH. L. REV. 498, 536-37 (2015) (considering standing in relation to the circumstances in which consumer patent actions may be appropriate); see also Sapna Kumar, Gene Patents and Patient Rights, 35 WhITTIER L. REv. 363, 370-72 (2014) (discussing the problem of standing specifically in challenging genetics-and genomics-related patents).

133. See Miller, supra note 130 , at $687-88$ (weighing the incentives and disincentives of patent validity challenges); see also Burstein, supra note 132, at 542-48 (demonstrating the "[m]isalignment [b]etween [c]urrent [s]tanding [r]ules and [i]ncentives to [b]ring [p]atent [c]hallenges").

134. See Strategic Decision Making, supra note 8, at 49-50 (contemplating administrative alternatives as one possible solution to the "collective action problem" presented by "expensive Article III litigation").

135. See 35 U.S.C. $\S \S 315(c), 325(c)$ (2018) (granting the Director the discretion to "join as a party to the inter partes review any person who properly files a petition"). 
petitioners. ${ }^{136}$ For example, for drug and medical-related patents, $48.5 \%$ of inter partes review petitioners are standard petitioners acting in a defensive posture. ${ }^{137}$ Among patents in the same field of technology, however, $70.8 \%$ of the inter partes review petitions actually filed had at least one standard petitioner associated with it. ${ }^{138}$ Similarly, the observed petitioners petition disparity for mechanical-related patents is $53.1 \%$ versus $70.2 \%$. ${ }^{139}$ These large joinder gaps suggest that nonstandard petitioners join petitions that standard petitioners have filed. ${ }^{140}$

Such joinders are permitted, of course, only if each underlying petition "warrants the institution of an inter partes review under section 314."141 In other words, whether standard or nonstandard, every petition must satisfy, among other things, the one-year time bar of $\S 315(\mathrm{~b})$ in order to be considered for joinder. ${ }^{142}$ The statutory boundaries between courts and the Patent Office give direct shape to the strategic uses that litigants make of these administrative proceedings. ${ }^{143}$

As a result, in the language of Cuozzo, the "scope and impact" of the one-year time bar extend necessarily beyond the walls of the Patent Office and into the courts. ${ }^{144}$ Ensuring compliance with the one-year time bar is certainly a necessary element of how the Patent Office must screen petitions, and this may

136. See Strategic Decision Making, supra note 8, at 74 (" $[\mathrm{I}] \mathrm{n}$ each of these technology areas, petitioners who are not prior defendants are joining petitions filed by prior defendants.").

137. See id. at 102-03 (displaying graphically the distribution of IPR petitioners that were defendants in a prior suit on the same patent, by technology).

138. See id. (displaying graphically the distribution of IPR petitions that included at least one standard petitioner).

139. See id. (showing the disparity in the amount of standard petitioners across different technologies).

140. See id. at 74 ("The disparities reveal that, in each of these technology areas, petitioners who are not prior defendants are joining petitions filed by prior defendants.").

141. 35 U.S.C. $\S 315$ (c).

142. See id. (outlining the requirements for joiner in IPR).

143. See generally Strategic Decision Making, supra note 8.

144. See Cuozzo Speed Techs., LLC v. Lee, 136 S. Ct. 2131, 2141 (2016) (considering the effects of appeals in cases in which statutes present constitutional questions or far reaching interpretive questions). 
suggest that the agency should enjoy unreviewable discretion in the matter. ${ }^{145}$ However, the larger power-allocation function that the one-year time bar serves as between the courts and the agency counsels strongly in favor of judicial review. ${ }^{146}$ This functional approach, for better or worse, was one that the Court itself articulated in Cuozzo. ${ }^{147}$

What was clear after Cuozzo was that, for a statutory limit on the Patent Office's screening power to be judicially reviewable, the limit had to be more than just analytically separable from the screening decision itself; it had to be separable by enough. ${ }^{148} \mathrm{By}$ concluding that the one-year time bar is, indeed, separable by enough-and is accordingly subject to judicial review ${ }^{149}$ - the en banc Federal Circuit produced two important benefits. First, it did much to clarify what the necessary and sufficient conditions are for that separability. Second, it placed a necessary brake on the Patent Office campaign of enlarging its sphere of nonappealability, though that campaign still had one further engagement.

\section{Resisting Review of Adjudicatory Obligations}

While the Federal Circuit was considering Wi-Fi One, the Supreme Court considered yet another case that implicated the agency's conflation of screening with adjudication. At issue in

145. See Wi-Fi One, LLC v. Broadcom Corp., 878 F.3d 1364, 1378 (Fed. Cir. 2018) (rehearing en banc) (Hughes, C.J., dissenting) (arguing that the timeliness requirement contained in the statute is "closely tied to the Director's decision to institute" and "is part of the Board's institution decision, and is therefore barred from judicial review").

146. See id. at 1377 (O'Malley, C.J., concurring) ("Allowing judicial review of erroneous determinations by the PTO as to whether the [statutory] time bar applies would prevent the agency from 'act[ing] outside its statutory limits,' one of the categories of 'shenanigans' envisioned by the majority in Cuozzo." (citing Cuozzo, 136 S. Ct. at 2141-42)).

147. See Wi-Fi One, 878 F.3d at 1377 (O'Malley, C.J., concurring) (discussing situations in which judicial appeals would be warranted); see generally Porous Court-Agency Border, supra note 114.

148. See Cuozzo, 136 S. Ct. at 2141 (distinguishing nonreviewable "screening" limits from reviewable limits "less closely related" to screening).

149. See Wi-Fi One, 878 F.3d at 1374 (concluding that "the statutory scheme as a whole demonstrates that $\S 315$ is not 'closely related' to the institution decision ... and it therefore is not subject to [the bar] on judicial review"). 
SAS Institute Inc. v. Iancu ${ }^{150}$ was the statutory requirement that the PTAB, as adjudicator, "shall issue a final written decision with respect to the patentability of any patent claim challenged by the petitioner." 151 Indeed, although the dispute in Wi-Fi One was quite well suited to testing the analytical reach of Cuozzo, the question on which the Court granted certiorari in $S A S$ Institute directly exposed what the Patent Office actually gained by conflating the power to screen petitions with the power to adjudicate them. . $^{152}$

The contested agency practice in SAS Institute was the routine issuance by the PTAB of final written decisions that address only some of the patent claims that the petitioner challenged.153 In its exercise of screening power, the PTAB frequently granted a petition in part and denied it in part, proceeding with review only as to certain patent claims or grounds. ${ }^{154}$ At the end of trial, the PTAB's final written decision adjudicated only those patent claims upon which the agency had initially granted review. ${ }^{155}$ The remaining patent claims from the initial petition, which had been filtered out up front, were not addressed. ${ }^{156}$ The Patent Office argued that it was free to cherrypick from petitions and to adjudicate fewer than all of the claims the petitioner had challenged. ${ }^{157}$ Governing Federal Circuit precedent said the same, including the panel decision in the $S A S$

150. 138 S. Ct. 1348 (2018).

151. Id. at 1354 (citing 35 U.S.C. § 318(a)).

152. Id.

153. See SAS Inst., Inc. v. ComplementSoft, LLC (SAS Inst. I), 825 F.3d 1341, 1352 (Fed. Cir. 2016) (asking if "a final written decision by the Board [must] address every patent claim challenged in an IPR petition").

154. See 37 C.F.R. $\$ 42.108$ (2019) (providing that "the Board may authorize the review to proceed on all or some of the challenged claims and on all or some of the grounds of unpatentability asserted for each claim").

155. See SAS Inst. II, $138 \mathrm{~S}$. Ct. at 1354 ("At the end of litigation, the Board issued a final written decision finding claims 1,3 , and $5-10$ to be unpatentable while upholding claim 4."); see also Synopsys, Inc. v. Mentor Graphics Corp., 814 F.3d 1309, 1311 (Fed. Cir. 2016) (holding that "the final order of the Board need not address every claim raised in the petition for review").

156. See SAS Inst. II, $138 \mathrm{~S}$. Ct. at 1354 ("[T] he Board's decision did not address the remaining claims on which the Director had refused review.").

157. See id. at 1355 ("In the Director's view, he retains discretion to decide which claims make it into an inter partes review and which don't."). 
Institute case itself. ${ }^{158}$ Governing Federal Circuit precedent said the same, including the panel decision in the SAS Institute case itself. 159

The Court rejected the position of the Patent Office and Federal Circuit, holding that the practice of partial institution was outside the statutory limits of the agency's authority. ${ }^{160}$ Accordingly, the Court also stated that the necessary scope of PTAB final written decisions cannot be narrowed by filtering out claims and arguments at the front end. ${ }^{161}$ And to reach both of these conclusions, the Court concluded as an initial matter that even though partial institution arose squarely in the exercise of the agency's screening power, that alone did not render the practice unreviewable. ${ }^{162}$ Under the framework of Cuozzo, the issue of partial institution represented agency action "in excess of statutory jurisdiction, authority, or limitations" and so was well within the "strong presumption in favor of judicial review." 163

As in Cuozzo and Wi-Fi One, what was notable about the framing of SAS Institute was neither the argument of the petitioner ${ }^{164}$ nor the controlling Federal Circuit precedent that was sought to be overturned.165 Instead, it was the litigation

158. See SAS Inst. I, 825 F.3d at 1352-53 (rejecting SAS's argument that the Board erred by not addressing every claim).

159. See id. (rejecting SAS's argument that the Board erred by not addressing every claim).

160. See SAS Inst. II, 138 S. Ct. at 1359 ("[E]verything in the statute before us confirms that SAS is entitled to a final written decision addressing all of the claims it has challenged ....").

161. See id. (agreeing with SAS' contention that "the Director exceeded his statutory authority by limiting the review to fewer than all of the claims SAS challenged").

162. See id. at 1359-60 ("[J]udicial review remains available consistent with the Administrative Procedure Act, which directs courts to set aside agency action 'not in accordance with law' or 'in excess of statutory jurisdiction, authority, or limitations."').

163. Id. at 1360 .

164. In this case, SAS Institute was both the PTAB petitioner seeking inter partes review in the PTAB and, eventually, the petitioner seeking certiorari in the Supreme Court. See Petition for a Writ of Certiorari at 4-5, SAS Inst. Inc. v. Lee, (No. 16-969), 2017 WL 491052 (U.S., Jan. 31, 2017) (noting that SAS petitioned for inter partes review of a patent and challenged patentability of all sixteen of the patent's claims).

165. See SAS Inst., Inc. v. Iancu, 138 S. Ct. 1348, 1354 (2018) (granting certiorari to review the Federal Circuit's rejection of SAS' argument that " 35 
position of the Patent Office-this time, about its underlying obligation of full and reasoned decision-making. ${ }^{166}$

The agency argument went essentially like this. Every administrative trial that results in a final written decision has gone through an initial screening. ${ }^{167}$ That initial screening and the resulting choice to proceed are immune from judicial review, including any agency choice to proceed as to part of the petition rather than all of it. ${ }^{168}$ Therefore, if the final written decision omits discussion of any part of the petition, that omission is unreviewable because it originates in the agency's unreviewable screening choices. ${ }^{169}$ Put another way, the Patent Office argued that even a statutory requirement pertaining directly to adjudication-which is subject to ordinary judicial review-can be made unreviewable by connecting some aspect of the adjudicatory task to the earlier threshold screening task.

This remarkable claim of agency power had appeared before. In the now-controlling Federal Circuit case that approved partial final written decisions by the PTAB, Synopsys, Inc. $v$. Mentor Graphics Corp., ${ }^{170}$ the Patent Office did not merely argue that its practice was entitled to deference under the Chevron doctrine for its reasonable resolution of ambiguous statutory language. ${ }^{171}$

U.S.C. $\S 318$ (a) required the Board to decide the patentability of every claim SAS challenged in its petition, not just some").

166. See id. (explaining that 35 U.S.C. $\S 318(a)$ (2018) obligates the Board to resolve the patentability of any patent claim challenged by the petitioner).

167. See id. at 1356 (noting that 35 U.S.C. $\$ 314$ (a) requires the Director to initially decide whether the petitioner is likely to succeed on "at least 1" claim).

168. See id. at 1359 (stating that 35 U.S.C. " $\$ 314$ (d) precludes judicial review only of the Director's 'initial determination' under $\S 314$ (a) that there is a 'reasonable likelihood' that the claims are unpatentable on the grounds asserted and review is therefore justified").

169. See Brief for Respondent ComplementSoft, LLC at 24, SAS Inst. Inc. v. Matal, 138 S. Ct. 350 (2017) (No. 16-969), 2017 WL 3948186 ("Faced with a petition that meets its burden as to some claims but not others, the. Board has basically unreviewable discretion to deny the IPR in full, rather than waste its limited resources addressing claims for which the petitioner has not shown even a reasonable likelihood of success ....").

170. 814 F.3d 1309 (Fed. Cir. 2016).

171. See id. at 1316 (opining that the regulation "setting forth the standards for the showing of sufficient grounds to institute" inter partes review is a "reasonable interpretation of the statutory provision governing the institution of inter partes review" (citing Chevron U.S.A., Inc. v. Nat. Res. Def. Council, Inc., 
Foremost, the agency argued that even the scope of its adjudication was unreviewable and that there was no jurisdiction even to hear the appeal. ${ }^{172}$ The Federal Circuit disagreed, and the Synopsys precedent that SAS Institute went on to challenge rested primarily on a theory of Chevron deference amid competing constructions of the statute prescribing final written decisions. ${ }^{173}$

The competing statutory constructions also implicated the presumption that agency actions are reviewable, in the same way as Justice Alito's dissent in Cuozzo had explained. ${ }^{174}$ The Federal Circuit in Synopsys gave great weight to the seeming difference in text between the screening and adjudication statutes for inter partes review. ${ }^{175}$ The former provides that a petition shall not be accepted for review absent a "reasonable likelihood that the petitioner would prevail with respect to at least 1 of the claims challenged in the petition." 176 The latter provides that a final written decision must address "any patent claim challenged by the petitioner and any new claim added under section 316(d)."177 The latter also makes the issuance of a final written decision conditional, requiring it "[i]f an inter partes review is instituted and not dismissed under this chapter." 178

\section{U.S. 837 (1984))).}

172. See id. at 1314 ("The decision of the Board to institute inter partes review cannot be appealed."); Brief for Intervenor-Director of the United States Patent and Trademark Office at 14-15, Synopsys, 184 F.3d 1309 (Nos. 2014-1516, 2014-1530), 2015 WL 1029522 (arguing that the institution decision is not reviewable because Congress authorized "this Court to review only the Board's final written decision as to patentability" (citing 35 U.S.C. $\S \S 319$, 318(a))).

173. See Synopsys, 814 F.3d at 1316 (stating that, under Chevron, the PTO's regulation allowing the Board to institute as to some or all of the claims is a reasonable interpretation of the statutory provision governing the institution of inter partes review).

174. See Cuozzo Speed Techs., LLC v. Lee, 136 S. Ct. 2131, 2150 (2016) (Alito, J., concurring in part and dissenting in part) ("If a provision can reasonably be read to permit judicial review, it should be.").

175. See Synopsys, 814 F.3d at 1314-15 ("Congress explicitly chose to use a different phrase when describing claims raised in the petition for inter partes review in $\S 314$ (a) and claims on which inter partes review has been instituted in $\S 318(a) . ")$.

176. 35 U.S.C. $\S 314$ (a) (2018) (emphasis added).

177. Id. $\S 318(\mathrm{a})$ (emphasis added).

178. Id. 
From these provisions, both the Patent Office and the Federal Circuit had inferred legislative intent that patent claims on which a final written decision is required are different from patent claims that undergo initial screening. The reasoning was that Congress had used the phrase "claims challenged by the petitioner" to distinguish from "claims challenged in the petition."179 To reach this conclusion, however, the Federal Circuit had ignored the rest of the statutory text. Because the patent owner itself may introduce amended patent claims during the proceeding, ${ }^{180}$ the final written decision must address not only what was initially challenged in the patent (and subjected to screening), but also what was later amended into the patent. ${ }^{181}$ Thus, a more immediately sensible reading is that Congress used the phrase "claims challenged by the petitioner" to distinguish from new claims added by the patent owner-and to clarify that the final written decision must address both. ${ }^{182}$ The upshot of this reading was that screening and adjudication would remain analytically separate, and adjudication would remain subject to judicial review. ${ }^{183}$

Similarly, the Federal Circuit had taken the conditional phrase "[i]f an inter partes review is instituted" and inferred from it that Congress intended to limit final written decisions not merely to cases that are instituted, but to the extent that they are instituted. ${ }^{184}$ This, too, ignored the language that comes next.

179. See Synopsys, 814 F.3d at 1315 (explaining that at the first stage, the Board reviews "claims challenged by the petitioner" while at the second stage, the Board issues a decision as to "claims challenged in the petition" (quoting 35 U.S.C. § 314(a) (2018); id. §318(a))).

180. See 35 U.S.C. § 316(d) (during IPR the patent owner can amend the patent by canceling a claim or offering "reasonable substitute claims").

181. Id. § 318(a).

182. See id. (stating that the Board "shall issue a final written decision with respect to the patentability of any patent claim challenged by the petitioner and any new claim added under section $316(\mathrm{~d})$ ").

183. See 35 U.S.C. $\$ 319$ ("A party dissatisfied with the final written decision of the Patent Trial and Appeal Board under section 318(a) may appeal the decision ....").

184. See Synopsys, Inc. v. Mentor Graphics Corp., 814 F.3d 1309, 1315 (Fed. Cir. 2016) (concluding that this conditional phrase in the statute "strongly suggests that the 'challenged' claims referenced are the claims for which inter partes review was instituted, not every claim challenged in the petition"). 
Another sensible reading was that Congress intended not to require final written decisions where review was dismissed through, e.g., settlement. ${ }^{185}$ This would have reflected a sound desire for economy in PTAB resources. Indeed, the statute that governs settlement of inter partes review directly invokes judicial economy by providing for termination "unless the Office has decided the merits of the proceeding before the request for termination is filed." 186

On both lines of reasoning, then, the statute governing final written decisions could reasonably -indeed, most sensibly - have been read in a way that respects the presumption of reviewability. For that reason alone, the Court's eventual decision in SAS Institute was correct. ${ }^{187}$ If instead the Patent Office's resurrected argument from Synopsys had prevailed, it would have been difficult to imagine what meaningful sphere of judicial supervision could long remain over administrative patent validity review. It is straightforward to connect $\mathrm{PTAB}$ screening to any number of downstream adjudicatory issues. If this logic could put even ordinary requirements of complete and reasoned agency decision-making beyond the reach of courts, then the statute furthest from initial screening would be "closely related" enough under Cuozzo to preclude review. ${ }^{188}$ Either such an outcome would have been a significant misreading of Cuozzo, or else the Court's assurances in Cuozzo would, indeed, have rung hollow. ${ }^{189}$

185. See 35 U.S.C. $\S 317$ (a) (codifying settlement protocol of inter partes review).

186. Id.

187. See Cuozzo Speed Techs., LLC v. Lee, 136 S. Ct. 2131, 2150 (2016) (Alito, J., concurring in part and dissenting in part) ("If a provision can reasonably be read to permit judicial review, it should be.").

188. See id. at 2141 ("[W]e need not, and do not, decide the precise effect of $\S 314(d)$ on appeals that implicate constitutional questions, that depend on other less closely related statutes ....").

189. See $i d$. ("[W]e do not categorically preclude review of a final decision where a petition fails to give 'sufficient notice' such that there is a due process problem with the entire proceeding, nor does our interpretation enable the agency to act outside its statutory limits ...."). 


\section{Effects of Aggrandized Agency Power}

Part II recounted the agency's trajectory of self-aggrandizement at the expense of the courts, both through administrative panel stacking to reach desirable case outcomes and through increasingly expansive positions about its immunity from judicial review. This Part reveals just what the agency stands to gain from these unusually aggressive policies, as well as what systemic harms these policies inflict. Part III.A discusses the benefits that accrue to the Patent Office, benefits that largely work to solidify recent enlargements of the agency's power. Part III.B discusses several systemic harms that these agency choices have imposed and continue to impose. Part III.C explores alternatives other than judicial review that might be expected to discipline questionable Patent Office choices, but concludes that these are inadequate in a system where patent rights are managed through a decentralized process of adjudication.

\section{A. Resulting Agency Benefits}

Both sets of benefits to the Patent Office are roughly the same. The agency has used panel stacking as a basis for Chevron deference, signaling an important departure from recent practice. ${ }^{190}$ The persistent and increasingly broad arguments about nonappealability are similarly aimed at securing greater autonomy from the courts, but simply under the heading of unreviewable discretion rather than deference. ${ }^{191}$

190. See Stuart Minor Benjamin \& Arti K. Rai, Administrative Power in the Era of Patent Stare Decisis, 65 DuKE L.J. 1563, 1573 (2016) (noting that the agency has argued that it is entitled to Chevron deference because a rule governing post-grant proceedings "allow[s] decisions regarding preliminary institution of review and final decisions to be made by the same panel").

191. See id. ("[T] he agency has asserted that the [America Invents Act of 2011] effectively insulates the PTAB's preliminary institution of review decisions from judicial review, even when the PTAB's final decision on the merits is later appealed."). 


\section{Chevron Deference from Panel Stacking}

An important effect of Patent Office aggrandizement is that the agency has begun using panel stacking as a basis to seek Chevron deference for PTAB decisions. ${ }^{192}$ This marks a shift in Patent Office policy, which until recently had been characterized by a reluctance to "expend political capital in generating Chevron-ready opinions." 193 The necessary and sufficient conditions within the PTAB for Chevron deference to apply are contested. ${ }^{194}$ Still, the Patent Office procedures for designating PTAB opinions as precedential likely satisfy these conditions. ${ }^{195}$ The practice of panel stacking likely does not.

The familiar starting points for whether Chevron is applicable are a delegation by Congress of authority for an agency to "speak with the force of law" and an exercise by the agency of that authority. ${ }^{196}$ In practice, speaking with the force of law may impose a high bar for adjudicatory orders, as Thomas Merrill and Kristin Hickman have proposed. ${ }^{197}$ On this view, the order must be binding not only on the parties involved but also on others inside the agency, i.e., must be reviewed by the agency head and

192. See id. at 1574 (explaining "[t]he PTO has repeatedly claimed Cheuron deference for its rules governing post-grant proceedings" which "allow decisions regarding preliminary institution of review and final decisions to be made by the same panel").

193. See id. at 1590, 1596 (opining that the PTO has failed to "place itself in the strongest position for receiving Chevron deference").

194. See id. at 1581-84 (summarizing the debate over whether "adjudications overseen by agency heads and/or treated as precedential by the agency" are the only adjudications that merit Cheuron deference). The discussion that follows is adapted from Professors Benjamin and Rai's summary.

195. See id. at 1584-85 ("PTAB procedures resemble the sort of uncoordinated decision-making process that Mead identified as an indicator of decisions that lack the force of law.").

196. See United States v. Mead Corp., 533 U.S. 218, 219, 226-27 (2001) (stating that such delegation can be apparent when "Congress would expect the agency to be able to speak with the force of law when addressing ambiguity in the statute or fills a space in the enacted law").

197. See Thomas W. Merrill \& Kristin E. Hickman, Chevron's Domain, 89 GEO. L.J. 833, 908 (2001) (arguing that "initial decisions are merely recommendations to a higher body within the agency" and are not entitled to Cheuron deference). 
carry precedential force upon other agency adjudications. ${ }^{198}$ Alternatively, adjudicatory orders deserve Cheuron deference virtually routinely, as Cass Sunstein has proposed. ${ }^{199}$ On this view, the order need bind only the parties involved, as adjudicatory orders generally do. ${ }^{200}$ This debate is also the subject of a circuit split. At one side are the Second, Ninth, and Tenth Circuits consistent with Merrill and Hickman's approach. ${ }^{201}$ At the other side is the Eleventh Circuit consistent with Sunstein's approach. ${ }^{202}$

As applied to the Patent Office, John Golden has argued that the stricter standard is appropriate for routine PTAB opinions and that such opinions would likely fail under Chevron deference. ${ }^{203}$ Benjamin and Rai agree to some extent, as routine PTAB opinions "resemble the sort of uncoordinated decision-making process that Mead identified as an indicator of

198. See id. ("An adjudicatory order should be understood to have the 'force of law' in this context only if it is legally binding both inside the agency (that is, binding on other agency personnel) and outside the agency (that is, binding on the parties to the adjudication).").

199. See Cass R. Sunstein, Cheuron Step Zero, 92 VA. L. REv. 187, 222 (2006) ("Cheuron deference is inferred from the grant of power to make decisions that people violate at their peril.").

200. See id. at 222 ("[A]n agency decision may be taken to have the force of law' when it is binding on private parties in the sense that those who act in violation of the decision face immediate sanctions.").

201. See Benjamin \& Rai, supra note 190, at 1584-85 nn.129, 132 \& 134 (declining to extend Chevron deference to "any statutory construction of the [Immigration and Nationality Act] set forth in a summarily affirmed [immigration judge] opinion" (citing Lin v. U.S. Dep't of Justice, 416 F.3d 184 (2d Cir. 2005)); see also Lagandaon v. Ashcroft, 383 F.3d 983 (9th Cir. 2004) (finding that review of the Board of Immigration Appeals' interpretation of the INA is not precluded where it entailed no exercise of discretion); Olson v. Fed. Mine Safety \& Health Review Comm'n, 381 F.3d 1007 (10th Cir. 2004) (stating that an ALJ decision that has not been reviewed by the Federal Mine Safety and Health Review Commission is not entitled to Chevron deference).

202. See Benjamin \& Rai, supra note 190, at 1585 n.135 (noting that the Eleventh Circuit in Florida Medical Center "afforded Chevron deference to an ALJ decision that was not subject to higher-level review" (citing Fla. Med. Ctr. of Clearwater, Inc. v. Sebelius, 614 F.3d 1276 (11th Cir. 2010))).

203. See John Golden, Working Without Chevron: The PTO as Prime Mover, 65 DUke L.J. 1657, 1685 (2016) ("PTAB decisions in inter partes, covered business method, and post-grant review are unlikely to be viewed as warranting Cheuron deference."). 
decisions that lack the force of law."204 They ultimately conclude, however, that the Patent Office Director's necessary review and approval in designating $\mathrm{PTAB}$ opinions as precedential does make those opinions eligible for Chevron even under the more stringent view of Mead that Merrill, Hickman, and Golden take. ${ }^{205}$

The case of panel stacking is murkier. The statutory authority of the Director includes the ability to designate PTAB panels of "at least" three PTAB members. ${ }^{206}$ Similarly, the Director and other agency leadership are themselves members of the PTAB by statute. ${ }^{207}$ This suggests, on first impression, that politically motivated designations of additional judges for rehearings may be acceptable. ${ }^{208}$ But apart from whether the Federal Circuit's approval of this practice's predecessor under the facts of Alappat remains viable in the current structure of the Patent Office ${ }^{209}$ - and there is reason to believe it does not ${ }^{210}$ panel stacking is also a dubious means for developing the institutional coherence needed to speak with the force of law.

Yet this is precisely what the Patent Office has argued. ${ }^{211}$ One example is Yissum, the first of the three above-discussed cases in which the agency confirmed its panel stacking practice to the Federal Circuit. ${ }^{212}$ The Patent Office in that case sought

204. Benjamin \& Rai, supra note 190 , at 1585.

205. See id. at 1586 (noting that the PTO's process "would seem to satisfy the more demanding of the two interpretations of Mead").

206. 35 U.S.C. $\S 6(c)(2018)$.

207. Id. §6(a).

208. Id.

209. See infra Part II.A (explaining that the BPAI was the predecessor of the PTAB and differed in important ways, making Alappat distinguishable from the present context).

210. See infra Part III.B.1 (noting that the difference between Alappat's BPAI and today's PTAB is directly relevant to the Director's supervisory authority over the policy choices reflected in administrative panel decisions).

211. Brief for Intervenor-Director of the United States Patent and Trademark Office at 19-20, Yissum Research Dev. Co. of the Hebrew Univ. of Jerusalem v. Sony Corp., 626 F. App'x 1006 (Fed. Cir. 2015) (Nos. 2015-1342, 2015-1343) [hereinafter Brief for USPTO] (arguing that the Board is entitled to Chevron deference because the USPTO "has acted to ensure that its pronouncements remain consistent" across multiple Board hearings).

212. See supra note 39 and accompanying text (showing that the agency reconfigures panels in order to ensure that the Director's policy position is being 
Cheuron deference for its interpretation of how the statutory joinder and one-year time bar statutes interact in inter partes review proceedings. ${ }^{213}$ The joinder statute gives discretion to the Director to join as a party to an instituted inter partes review "any person who properly files a petition" that, in the Director's view, would itself have warranted review. ${ }^{214}$ The one-year time bar, meanwhile, does not apply to "a request for joinder."215

Patent owner Yissum distinguished between the joinder of parties contemplated by the statute and the joinder of arguments, which is unmentioned. ${ }^{216}$ Yissum argued that the agency had previously granted late motions to join arguments but lately had "flipped and then flopped," noting that the statute permitting late joinder of arguments was impermissible. ${ }^{217}$ The result, Yissum urged, was an inconsistent agency position that was undeserving of Cheuron deference. ${ }^{218}$

The Patent Office maintained that its consistently held position was to permit the late joinder of arguments. ${ }^{219}$ It is supposed flip to forbidding such late joinders came from a panel

enforced by the panels).

213. See Brief for USPTO, supra note 211, at 19 (arguing that "this Court should defer to the Board's reasonable interpretation of the statute here because the statute is ambiguous" (citing Chevron U.S.A., Inc. v. Nat. Res. Def. Council, Inc., 467 U.S. 837, 842-43 (1984)).

214. 35 U.S.C. $\S 315$ (c) (2018).

215. Id. §315(b).

216. Yissum's Opening Brief at 32-33, Yissum Research Dev. Co. of the Hebrew Univ. of Jerusalem v. Sony Corp., 626 F. App'x 1006 (Fed. Cir. 2015) (Nos. 2015-1342, 2015-1343) (noting that "the statute 'unambiguously does not' permit late joinder of issues, and that the legislative history showed that Congress intended only late joinder of parties, and not of issues").

217. Id. The term "late motion" refers to a motion that comes after the one-year time bar of $\S 315$ (b). See 35 U.S.C. $\S 315(b)$ ("An inter partes review may not be instituted if the petition requesting the proceeding is filed more than 1 year after the date [on which the complaint is served].").

218. See Yissum's Opening Brief supra note 216, at 33 (citing Thomas Jefferson Univ. v. Shalala, 512 U.S. 504, 515 (1994)) (“[A]n agency's interpretation of a statute or regulation that conflicts with a prior interpretation is entitled to considerably less deference than a consistently held agency view.").

219. See Brief for USPTO, supra note 211, at 19-20 (stating that the USPTO had acted to ensure that its pronouncements remained consistent on the issue of late joinder of arguments). 
decision in Target Corp. v. Destination Maternity Corp. ${ }^{220,} 221$ Recognizing the inconsistency, the agency leadership granted rehearing and expanded the panel to reach the opposite, correct outcome. ${ }^{222} \mathrm{By}$ this account, even if panel stacking is problematic on its own terms, it seems to be an effective vehicle for ensuring uniformity in implementing the policy preferences of the Director. ${ }^{223}$ To that extent, at least, the agency might have spoken consistently enough for the Chevron deference that it sought.

One problem with this account is that it requires a party request for rehearing. 224 As the Patent Office conceded in its briefing for Yissum, the PTAB did deny late joinder in another case as being statutorily impermissible - and that case remained uncorrected. ${ }^{225}$ The petitioner in that proceeding declined to seek rehearing, apparently denying the PTAB "the same opportunity to ensure consistency." 226 If true, it is certainly questionable for an agency decision's precedential force to be held hostage to litigant strategy in this manner.

An even more fundamental problem with the Patent Office's account of consistency through panel stacking is that the agency did it multiple times in the Target case. The original PTAB panel consisted, as usual, of three judges. ${ }^{227}$ As the deadline for decision

220. No. IPR2014-00508 (P.T.A.B. Sept. 25, 2014).

221. See Decision Denying Motion for Joinder at 11, Target Corp., No. IPR2014-00508 (stating that the joinder statute "bars institution of an inter partes review based on a petition filed more than 1 year after the date on which the petitioner is served with a complaint alleging infringement of the patent").

222. See Decision Granting Petitioner's Request for Rehearing at 1, Target Corp., No. IPR2014-00508 (P.T.A.B. Feb. 12, 2015) (expanding the panel to seven administrative patent judges).

223. See Brief for USPTO, supra note 211 , at 20 (concluding that " $[\mathrm{t}]$ he USPTO thus has acted to ensure that its pronouncements remain consistent on this issue").

224. See 37 C.F.R. $§ 42.71$ (d) (2019) (conferring the power to seek rehearing upon a "party dissatisfied with a decision").

225. See Brief for USPTO, supra note 211, at 20 n.4 (noting that the Board held in Skyhawke Techs., LLC v. L\&H Concepts, LLC, No. IPR2014-01485 (P.T.A.B. Mar. 20, 2015) that " $\$ 315(\mathrm{c})$ does not permit joinder of additional grounds by the same party").

226. Id.

227. See Order on the Conduct of the Proceedings at 1, Target Corp., No. IPR2014-00508 (P.T.A.B. Mar. 24, 2014) (limiting the panel to three administrative patent judges). 
drew near, however, the PTAB on its own initiative expanded the panel to five judges, and it was this panel who issued the supposedly aberrant decision to deny joinder. ${ }^{228}$ The PTAB's internal procedures for panel stacking do permit this sort of sua sponte expansion. ${ }^{229}$ The panel, in fact, need not await a request for rehearing - the internal request may come even in advance of a decision by the current panel. ${ }^{230}$

Thus, the only way for the expanded five-judge panel in Target to have denied joinder as being impermissible was that all three judges originally on the panel were planning to rule in this way. Indeed, this is just what happened.231 The agency added two judges to the panel, hoping to sway one of the original three and thus produce a 3-2 decision allowing joinder. None of the three judges were swayed, however, and the result was a 3-2 decision denying joinder and frustrating the agency's first, preemptive attempt at panel stacking. ${ }^{232}$ Only upon rehearing did the agency leadership add yet another two judges to the panel so that a 4-3 decision allowing joinder could be assured. ${ }^{233}$ Even then, the three judges on the original panel, now outnumbered, issued a dissent adhering to their original position ${ }^{234}$ just as they dissented from the re-stacked panel's order granting rehearing at

228. See Decision Denying Motion for Joinder, Target Corp., No. IPR2014-00508 (P.T.A.B. Sept. 25, 2014) (denying petitioner's motion for joinder).

229. See U.S. Patent \& Trademark Office, Patent Trial and Appeal Board Standard Operating Procedure 1 (Rev. 14) Assignment of Judges to Merits Panels, Interlocutory Panels, and Expanded Panels $\S \mathrm{III}(\mathrm{C})$, https://perma.cc/9M96-UXZ9 (PDF) ("A judge, a merits panel, or an interlocutory panel may suggest ... the need for the designation of an expanded panel.").

230. Id. § III(A)(3).

231. See Decision Denying Motion Joinder, Target Corp., No. IPR2014-00508 (P.T.A.B. Sept. 25, 2014) (in which the three judges from the original panel, Bisk, Fitzpatrick, and Weatherly, joined in the majority).

232. See id. (denying joinder despite the dissent of Administrative Judges Green and Giannetti).

233. See Decision Motion for Joinder, Target Corp., No. IPR2014-00508 (P.T.A.B. Feb. 12, 2015) (listing a decision by Administrative Judges Tierney, Green, Change, Giannetti, Bisk, Fitzpatrick, and Weatherly).

234. See id. at 7 ("Section 315(c) does not authorize joinder of proceedings."). 
all. ${ }^{235}$ This, too, calls into question the agency's claim that it has spoken with the force of law and consistently enough for Chevron deference.

This approach by the agency achieves its preferred results not through clear, foreordained legal criteria-nor even through clear, foreordained designations of which preferred precedents are to be followed-but simply through incrementalistic political fiat. It reflects a view on the part of the Patent Office that deciding cases in an opaque manner is preferable to deciding them in a transparently political one even where the decisions themselves may have been politically defensible. This sort of $s u b$ rosa decision-making in the guise of adjudication is not only problematic, but also unnecessary. Other mechanisms already exist for singling out desirable cases for their precedential value and for offering reasoned explanations that are backed by the prevailing policy of the executive. ${ }^{236}$

\section{Autonomy from the Courts Without Chevron}

Patent Office aggrandizement also had a second, more subtle effect for a time, though the agency has suffered some recent retrenchment. That effect is greater autonomy from judicial scrutiny outside the framework of Chevron or other forms of deference. The nonappealability of threshold decisions whether to institute PTAB review was undoubtedly a legislative choice aimed at shielding initial agency screening choices from disruptive judicial scrutiny prior to a final judgment. ${ }^{237}$ The

235. See Decision-Granting Petitioner's Request for Rehearing, Target Corp. v. Destination Maternity Corp., No. IPR2014-00508 (P.T.A.B. Feb. 12, 2015)

We would deny rehearing because 35 U.S.C. $\$ 315$ (c) does not provide for the relief requested by Petitioner and because its Petition is barred by 35 U.S.C. $\S 315(b)$. Additionally, we would deny rehearing because Petitioner has not identified any matter it believes the Decision Denying Joinder misapprehended or overlooked, or how that matter was previously addressed.

236. See, e.g., Richard A. Posner, How Judges Think 175-76 (2008) (describing the process of "reasoning by analogy" in the use of precedent).

237. See Porous Court-Agency Border, supra note 114, at 1090-91 ("[T] border represents the intention of Congress to allocate power differently between the courts and the Patent Office, but not to divest either institution 
expansion of that nonappealability beyond initial screening, however, undermines the border that Congress put in place between the Patent Office and the Article III courts, and arrogates further power from the courts to the agency.

Expansionary influences like this are especially powerful early in a new legal regime, and often create substantial path-dependence. ${ }^{238}$ By the agency's good luck, the initial years of PTAB adjudication under the AIA saw Patent Office arguments largely succeed. The first Federal Circuit case to construe the agency's nonappealable screening power was St. Jude Medical $v$. Volcano Corp., ${ }^{239}$ in which the panel held that the PTAB's denial of a petition was not appealable. ${ }^{240}$ On the very same day as the St. Jude decision, the Federal Circuit also explained that the screening power was generally beyond even the judicial power of mandamus to correct, regardless whether the PTAB had granted review $^{241}$ or denied review. ${ }^{242}$ From these premises, it was-at least analytically-a fairly small step to hold, as the Federal Circuit panel in Cuozzo did hold, that PTAB decisions to proceed with review remain nonappealable even after final judgment. ${ }^{243}$

completely.").

238. See Maxwell L. Stearns, Standing Back from the Forest: Justiciability and Social Choice, 83 CAL. L. REV. 1309, 1349-50 (1995) (critiquing the stare decisis effect of privileging the view of the first court to adjudicate an issue over that of the second); see also Oona A. Hathaway, Path Dependence in the Law: The Course and Pattern of Legal Change in a Common Law System, 86 IowA L. REv. 601, 605 (2001) ("The doctrine of stare decisis thus creates an explicitly path-dependent process.").

239. 749 F.3d 1373 (Fed. Cir. 2014).

240. See id. at 1375 ("We base [the decision] on the structure of the inter partes review provisions, on the language of section 314 (d) within that structure, and on our jurisdictional statute read in light of those provisions.").

241. See In re Procter \& Gamble Co., 749 F.3d 1376, 1377 (Fed. Cir. 2014) (concluding that immediate review of a decision to institute an inter partes review is not available).

242. In re Dominion Dealer Sols., LLC, 749 F.3d 1379, 1379 (Fed. Cir. 2014) ("[T] he relevant statutory provisions make clear that we may not hear an appeal from the Director's decision not to institute an inter partes review.").

243. See In re Cuozzo Speed Techs., 793 F.3d 1268, 1273 (Fed. Cir. 2015) (discussing St. Jude Med., Cardiology Div., Inc. v. Volcano Corp., 749 F.3d 1373, 1375-76). 
In a similar turn, the first Federal Circuit case to address whether the one-year time bar of inter partes review is judicially reviewable was Achates Reference Publishing $v$. Apple. ${ }^{244}$ The panel in that case held that the PTAB's determinations regarding the one-year time bar were part of the exercise of its screening power and so were nonappealable. ${ }^{245}$ As a result, the Federal Circuit, in a series of cases that followed, affirmed all of the agency's applications of the time bar. ${ }^{246}$ This was not because the agency was regularly correct, but because until the en banc reversal in Wi-Fi One, the Federal Circuit was bound not even to consider the issue. ${ }^{247}$

The resulting autonomy for the Patent Office to act without any judicial check on its practices has been substantial. Importantly, this argument about agency autonomy from the courts is distinct from John Golden's recent suggestion that the Patent Office can meaningfully compete with Article III courts, including the Federal Circuit, without Chevron deference by acting instead through the agency's position as first mover on a range of patent law and policy questions. ${ }^{248}$ Whereas Golden

244. See 803 F.3d 652, 658 (Fed. Cir. 2015) ("We thus hold that 35 U.S.C. $\S 314(\mathrm{~d})$ prohibits this court from reviewing the Board's determination to initiate IPR proceedings based on its assessment of the time-bar.").

245. See id. at 653 ("Because the Board's determinations to institute IPRs in this case are final and nonappealable under 35 U.S.C. $\S 314(d)$, this court lacks jurisdiction and dismisses the appeals.").

246. See, e.g., Click-to-Call Techs., LP v. Oracle Corp., 622 F. App'x. 907, 907-08 (Fed. Cir. 2015), vacated, 136 S. Ct. 2508 (2016) (dismissing the appeal for lack of jurisdiction based on the reasoning in Achates Reference Publishing); MCM Portfolio, L.L.C. v. Hewlett-Packard Co., 812 F.3d 1284, 1288-89 (Fed. Cir. 2015) ("The law is clear that there is 'no appeal' from the decision to institute inter partes review. . . Achates controls here."); Synopsys, Inc. v. Mentor Graphics Corp., 814 F.3d 1309, 1323 (Fed. Cir. 2016), overruled by Aqua Products, Inc. v. Matal, 872 F.3d 1290 (Fed. Cir. 2018) ("This issue is not appealable pursuant to $\S 314(d)$."); Shaw Indus. Grp., Inc. v. Automated Creel Sys., Inc., 817 F.3d 1293, 1301 (Fed. Cir. 2016) ("[B]ased on Achates, we lack jurisdiction to review this aspect of the Board's decision."); Wi-Fi One, L.L.C. v. Broadcom Corp., 837 F.3d 1329, 1333 (Fed. Cir. 2016), vacated, 878 F.3d 1364, 1374-75 (Fed. Cir. 2018) (upholding the Achates decision).

247. Wi-Fi One, L.L.C. v. Broadcom Corp., 878 F.3d 1364, 1367 (Fed. Cir. 2018) ("We therefore hold that the time-bar determinations under 315(b) are appealable, overrule Achates's contrary conclusion, and remand these cases to the panel for further proceedings consistent with this opinion.").

248. See Golden, supra note 203, 1691-98 ("D]espite such constraints, the PTO can still accomplish much through adjudicatory processes as patent law's 
argues that the Patent Office can influence patent law by acting first and framing issues for judicial development, ${ }^{249}$ the argument developed here is that the Patent Office seeks to broaden its influence by reducing judicial oversight that would otherwise operate upon it. Thus, far from steering the court-agency dialogue in directions that the Patent Office might want, the agency's push to interpret the $\mathrm{PTAB}$ nonappealability statute increasingly broadly is better understood as cutting off more and more of the dialogue altogether.

\section{B. Resulting Systemic Harms}

Where the Patent Office has benefited from this sustained pattern of aggrandizement, however, the patent system has suffered several notable harms. The particular details of panel stacking have done injury to due process, and the result-oriented posture of injecting political judgments into patent validity has likewise done injury to the property interests that inhere in patent rights. Meanwhile, both panel stacking and the evading of judicial review have undermined the agency's ability to make credible commitments. Finally, the Federal Circuit's initial acceptance of agency arguments about nonappealability has weakened the long-term prospect of oversight upon the agency's future behavior.

\section{Injury to Due Process}

As multiple judges of the Federal Circuit have suggested, panel stacking by the Patent Office presents a significant injury to due process in the form of "fundamental rule of law questions" such as "predictability and uniformity and transparency of judgments and neutrality of decision makers."250 Given the

probable 'prime mover'- the government body that is likely to be the first to address many patent law issues in a centralized and systematic fashion.").

249. See id. at 1694 ("[I]n part through the issuance of guidance documents that do not have the force of law, the PTO has already shown a capacity to influence the substantive course of patent law's development.").

250. See supra notes $39-52$ and accompanying text (exemplifying threats to 
ascendant power of the Patent Office over the validity of already issued patents, the scale of this due process injury is correspondingly high. ${ }^{251}$ Thus far, the agency has defended the practice on the basis of a decision that is longstanding, but of questionable relevance. ${ }^{252}$ That decision, In re Alappat, ${ }^{253}$ represents a view of agency power that has possibly been overcome by intervening changes in the institutional environment of the Patent Office. ${ }^{254}$

In Alappat, the Commissioner for Patents, then the head of the agency, directed the Board of Patent Appeals and Interferences to rehear and reverse a case. ${ }^{255} \mathrm{He}$ did so by reconstituting the panel with enough others, including himself, to outvote the three-member panel who had made the initial decision. ${ }^{256}$ Patent applicant Kuriappan Alappat appealed, and the Federal Circuit affirmed the Commissioner. ${ }^{257}$

The facts of Alappat are similar in several respects to the current state of the agency. The BPAI as a whole is now reconstituted as the PTAB. ${ }^{258}$ The political head of the agency is now the Director rather than the Commissioner for Patents. ${ }^{259}$ The examiners-in-chief of "competent legal knowledge and

due process).

251. See Golden, supra note 248, at 1670 (discussing some limitations on the Patent Office's power "[d]espite the PTO's increased capacities").

252. See In re Alappat, 33 F.3d 1526, 1531-32 (Fed. Cir. 1994) (recognizing that authority of the Commissioner to designate an expanded panel "to consider a request for reconsideration of a decision"), abrogated by In re Bilski, 545 F.3d 943 (Fed. Cir. 2008).

253. 33 F.3d 1526 (Fed. Cir. 1994).

254. Alappat was abrogated by In re Bilski in 2008. Id. In 2012, Congress enacted the Leahy-Smith America Invents Act, "the largest patent reform since 1952." Steven J. Markovich, U.S. Patents and Innovation, CounCIL ForEIGN REL. (Dec. 12, 2012), https://perma.cc/C29P-3AG3 (last visited Sept. 16, 2019) (on file with the Washington and Lee Law Review).

255. See Alappat, 33 F.3d at 1531 ("The Examiner... requested reconsideration of this decision.").

256. See id. ("The Examiner further requested that such reconsideration be carried out by an expanded panel.").

257. Id.

258. See 35 U.S.C. $\S 6$ (2018) ("Any reference in any Federal law, Executive order, rule, regulation, or delegation of authority, or any document of or pertaining to the Board of Patent Appeals and Interferences is deemed to refer to the Patent Trial and Appeal Board.").

259. 35 U.S.C. $\$ 3$. 
scientific ability" who staffed the BPAI are now administrative patent judges who staff the PTAB. ${ }^{260}$ And just as the political leadership of the agency were expressly members of the BPAI with authority vested in the Commissioner to designate BPAI panels, so now the leadership of the agency are members of the $\mathrm{PTAB}$ with authority vested in the Director to designate PTAB panels. ${ }^{261}$

However, when Alappat was decided, the available pool of examiners-in-chief from which three-member panels were selected were employees appointed to the competitive service. ${ }^{262}$ By contrast, administrative patent judges are appointed by the Secretary of Commerce ${ }^{263}$ and are "inferior Officers" with "significant functions" and "substantial powers."264 This difference between Alappat's BPAI and today's PTAB is directly relevant to the Director's supervisory authority over the policy choices reflected in administrative panel decisions. ${ }^{265}$

The desire after Alappat to strengthen the political oversight power of the Patent Office head and to give the agency more

260. Compare 35 U.S.C. $§ 7(a)$ (1994) ("The examiners-in-chief shall be persons of competent legal knowledge and scientific ability, who shall be appointed to the competitive service."), with 35 U.S.C. $\S$ 6(a) (2018) ("The administrative patent judges shall be persons of competent legal knowledge and scientific ability.").

261. Compare 35 U.S.C. $\S 7(b)$ (1994) ("The Commissioner, the Deputy Commissioner, the Assistant Commissioners, and the examiners-in-chief shall constitute the Board of Patent Appeals and Interferences."), with 35 U.S.C. § 6(c) (2018) ("The Director, the Deputy Director, the Commission for Patents, the Commissioner for Trademarks, and the administrative patent judges shall constitute the Patent Trial and Appeal Board.").

262. See 35 U.S.C. § 7(a) (1994) ("The examiners-in-chief shall be persons of competent legal knowledge and scientific ability, who shall be appointed to the competitive service.").

263. See 35 U.S.C. § 6(a) (2018) ("The administrative patent judges shall be persons of competent legal knowledge and scientific ability who are appointed by the Secretary.").

264. See John F. Duffy, Are Administrative Patent Judges Unconstitutional?, 77 Geo. WaSH. L. Rev. 904, 906 (2009) (discussing Freytag v. Comm'r, 501 U.S. 868 (1991)) (internal quotations omitted).

265. Stuart Minor Benjamin \& Arti K. Rai, Administrative Power in the Era of Patent Stare Decisis, 65 DukE L.J. 1563, 1599 (2016) ("In the AIA, Congress ... gave the PTO enhanced authority (to be implemented in the first instance by the PTAB)."). 
autonomy expressly included the experiment of allowing the Director to appoint administrative judges. ${ }^{266}$ That experiment ultimately failed, and the reason was precisely that the burgeoning importance of administrative patent judges' duties and powers required their appointment by a "Head of Department" such as the Secretary of Commerce. ${ }^{267}$

That same importance counsels in favor of decisional independence for administrative patent judges as well. ${ }^{268}$ Such independence need not divest the Director of his obligation and authority to "provid[e] policy direction and management supervision" for the agency. ${ }^{269}$ The current process by which PTAB panels are reconfigured reasonably invokes as a justification the need "to secure and maintain uniformity of the Board's decisions." 270 For that uniformity to be obtained through result-oriented selection of additional judges, however, is problematic.

This problem also came before the Federal Circuit in Alappat, in the form of a due process challenge. 271 Although the court found the issue untimely and did not address it, certainly the Commissioner's desire for an "effective ability to review decisions" and to "exercise legal and policy control over decisions" by administrative judges seems reconcilable with due process, as Stuart Benjamin and Arti Rai have argued. ${ }^{272}$ In pursuit of that

266. See infra notes 454-455 and accompanying text.

267. See infra notes $456-458$ and accompanying text.

268. See Christopher J. Walker, Constitutional Tensions in Agency Adjudication, 104 IowA L. REv. 2679, 2698 (2019) ("Congress did not grant the Patent Office Director final decision-making authority over PTAB adjudications. Agency adjudicators on the PTAB are thus more insulated from political control that their peers at other agencies.").

269. 35 U.S.C. $\S 3(a)(2)(A)(2012)$.

270. See U.S. Patent \& Trademark Office, supra note 229 , at pt. III(A)(2) ("Consideration by an expanded panel is necessary to secure and maintain uniformity of the Board's decisions, such as where different panels of the Board render conflicting decisions on issues of statutory interpretation or rule interpretation, or a substantial difference of opinion among judges exists on issues of statutory interpretation.").

271. See In re Alappat, 33 F.3d 1526, 1536 (1994) (“Amicus Curiae FCBA suggests that the Commissioner's redesignation practices in this case violated Alappat's due process rights.").

272. See Benjamin \& Rai, supra note 190, at 1586-87 (expressing skepticism that the remaking of panels to accomplish policy objectives poses a due process 
purpose, however, the means properly available to the Director are not unbounded. ${ }^{273}$

For example, the Supreme Court has previously explained that "[a]s a member of the Board and the official responsible for selecting the membership of its panels, ... the Commissioner may be appropriately considered as bound by Board determinations." 274 Moreover, the power to rehear and re-adjudicate panel decisions carries with it an obligation to consider evidence and argument, for " $[t]$ he one who decides must hear."275 Thus, for members of the PTAB to be placed on a rehearing panel with foreknowledge that they "will come out the other way"276 improperly puts the decision ahead of the consideration of evidence and argument.

Meanwhile, another mechanism is already available to the Director for ensuring uniformity among PTAB decisions. Indeed, it is one that comports more fully with the nature of the PTAB as a quasi-judicial body with adjudicatory authority independent from the authority of the Director. ${ }^{277}$ That mechanism is the curation and designation of PTAB opinions as precedential, informative, or representative. ${ }^{278}$ By default, all panel opinions

concern).

273. See Duffy, supra note 264, at 911 ("[T]he PTO Director's primary duty-to "provid[e] policy direction and management supervision for the [PTO]'-is subject to the oversight of the Secretary of Commerce." (quoting 35 U.S.C. $\S 1$ (a) (2006)) (alterations in original)).

274. Brenner v. Manson, 383 U.S. 519, 523 n.6 (1966).

275. See Duffy, supra note 264, at 908 (citing Morgan v. United States, 298 U.S. 468, 481 (1936)) (explaining why evidence is crucial for administrative adjudication).

276. See supra note 39 and accompanying text (examination of Patent Office regarding panel stacking).

277. See Animal Legal Def. Fund v. Quigg, 932 F.2d 920, 928-29 (Fed. Cir. 1991) ("[T]he Board's authority to decide the section 101 issue rests on an independent grant in section 7(b), which requires the Board to decide patent validity issues when properly raised in Board proceedings, and is independent from the Commissioner's authority to establish regulations.").

278. See generally U.S. Patent \& Trademark Office, Patent Trial AND appeal Board Standard Operating Procedure 2 (Rev. 9) Publication of OPINIONS AND Designation OF OPINIONS AS PReCEdential, Informative, REPRESENTATIVE, AND ROUTINE, https://perma.cc/5ABH-JXLV (PDF) (explaining procedures for designating cases as precedential, informative, representative, or routine). The description that follows draws heavily from Saurabh 
are routine unless further action is taken. ${ }^{279}$ Representative opinions describe and curate routine opinions to give practitioners and the public a concise view of the case law on a certain issue. ${ }^{280}$ Informative opinions synthesize this descriptive survey into normative guidance for practitioners and the public to follow. ${ }^{281}$ Precedential opinions go the furthest and make the synthesis binding upon the PTAB itself. ${ }^{282}$

However, over the first six years of the PTAB's operations, the agency designated as precedential only ten opinions from the administrative trials conducted under the AIA.283 And in the main, these opinions pertain to the procedural structure of inter partes and covered business method reviews rather than to issues of substantive patent law. For the agency "to engage in casespecific readjudication" 284 via panel stacking, especially when it has the power to promote decisional uniformity in a prospective fashion by designating precedential opinions on which stare decisis can operate, represents significant injury to due process, all the more because the injury is unnecessary to inflict.

Vishnubhakat, Precedent and Process in the Patent Trial and Appeal Board, PATENTLYO (May 10, 2016), https://perma.cc/3KCX-BLUW (last visited Sept. 2, 2019) (on file with the Washington and Lee Law Review).

279. See Vishnubhakat, Precedent and Process in the Patent Trial and Appeal Board, supra note 278 ("[A]ll opinions are routine by default, and some further action is necessary to elevate an opinion's status.").

280. See id. ("Representative opinions offer a sample of typical decisional outcomes on a given matter.").

281. See id. ("Informative opinions articulate the PTAB's norms on recurring issues and offer guidance both on issues of first impression and on PTAB rules and practices.").

282. See id. ("The most difficult to designate and so the rarest are precedential opinions, which are binding in all future cases before the PTAB unless and until they are superseded by later binding authority.").

283. Patent Trial and Appeal Board, Precedential and Informative Decisions, Issues Specific to AIA Trial Proceedings, U.S. PAT. \& TradEMARK OFF., https://perma.cc/2J8Z-QZ25 (last visited Sept. 2, 2019) (on file with the Washington and Lee Law Review).

284. See supra note 42 and accompanying text. 


\section{Injury to Stable Patent Property Rights}

The prevailing view of patents as property rights suggests that stability and certainty in those rights is of chief concern. ${ }^{285}$ The current practices of Patent Office aggrandizement have compounded existing difficulties in the patent system's ongoing struggle to provide stable rights. ${ }^{286}$ The existing difficulties are well understood and need not be repeated here beyond a brief summary. ${ }^{287}$ However, the additional injuries to stable property rights in patents, both directly from panel stacking and indirectly from overbroad nonappealability, are different in kind and newer in the patent system's experience. ${ }^{288}$

Some of the more persistent challenges to the stability and certainty of patent property rights fall under four general headings. One is the tension in defining patent law principles in terms of predictable rules or flexible standards, a tension that is well-known across the law. ${ }^{289}$ The continually shifting and even disruptive nature of invention makes rules difficult to craft and

285. See John F. Duffy, Rules and Standards on the Forefront of Patentability, 51 WM. \& MARY L. REV. 609, 610 (2009) ("Patents convey property rights, and a substantial degree of certainty is usually thought to be helpful, or even essential to well functioning property rights."); see also Alan C. Marco \& Saurabh Vishnubhakat, Certain Patents, 16 YALE J.L. \& TECH. 103, 106 (2013) (explaining that uncertainty disincentivizes patents).

286. See Duffy, supra note 285, at 612 ("Thus, the Federal Circuit and its predecessor court have changed the rules governing patentable subject matter no less than three times in thirty years.").

287. See, e.g., id. at 612-13 (quoting AT\&T Corp. v. Excel Communications, Inc., 172 F.3d 1352, 1361 (Fed. Cir. 1999)) (explaining the short-lived reassurance of clear patent adjudication standards "in light of the refocusing of the $\S 101$ issue that Alappat and State Street have provided").

288. See Christopher J. Walker \& Melissa F. Wasserman, The New World of Adjudication, 107 CAL. L. REV. 141, 159-60 (2019) (describing the new Patent Office rules under the AIA regarding nonappealability and the Director's influence on PTAB outcomes).

289. See generally Cass R. Sunstein, Problems with Rules, 83 CaL. L. REv. 953, 957 (1995) ("In every area of regulation . . . it is necessary to choose between general rules and case-by-case decisions."); Louis Kaplow, Rules Versus Standards: An Economic Analysis, 42 DUKE L.J. 557, 616-17 (1992) (discussing how rules and standards change over time); Isaac Ehrlich \& Richard A. Posner, An Economic Analysis of Legal Rulemaking, 3 J. LEGAL STUD. 257 (1974) (discussing "the conditions under which greater specificity or greater generality is the efficient choice"). 
unlikely to survive in the long run. ${ }^{290}$ By contrast, standards may be more durable but none the clearer for that, as it is their very flexibility and openness to facts - especially technological facts in the context of patent law-that were not anticipated and planned-for that makes the outcomes of standards uncertain and unpredictable. ${ }^{291}$ Recent years have provided many examples of this tension in patent law, arising from the Supreme Court's repeated dissolution of the Federal Circuit's bright-line doctrinal rules. ${ }^{292}$

A second existing challenge to stable patent property rights is the lack of durability in important principles of patent law, even when they do take the form of fairly clear rules. As John Duffy has observed, "clarity without durability has limited value for a system in which long term investment in tomorrow's innovations is supposed to be fostered through property rights lasting for two decades." 293 For example, the doctrine of patent-eligible subject matter suffered this very fate repeatedly in the last forty years, with bright-rule Federal Circuit rules thwarted either by newer attempts at the same or by Supreme Court interventions to impose standards instead. 294

A third is the problem of notice, especially about the boundaries of the patent right. Claimants to knowledge resources such as invention may often have incentives to frame their claims vaguely, either because the cost of delineating precisely is high or because full information is not available yet about where among

290. See Duffy, supra note 285 , at 614 ("The unruly process of creative destruction has the power to undermine today's legal rules every bit as much as it renders obsolete today's industrial products, processes, and institutions.").

291. See id. ("[A] clear but transient rule may be inferior to a standard that is less clear and less predictable in application, but more durable.").

292. See Peter Lee, Patent Law and the Two Cultures, 120 Yale L.J. 2, 42-47 (2010) ("Beginning in the mid-1990s . . . the Supreme Court increasingly asserted its appellate jurisdiction over the Federal Circuit. . . . The Supreme Court's deference to Federal Circuit jurisprudence . . . appears to have ended."); Rochelle Cooper Dreyfuss, In Search of Institutional Identity: The Federal Circuit Comes of Age, 23 BERKELEY TECH. L.J. 787, 789, 797-800 (2008) (describing the relationship between the Supreme Court and the Federal Circuit).

293. Duffy, supra note 285 , at $614-15$.

294. See id. at 612-13, 623 (summarizing both the variety and evolution of Federal Circuit rules and Supreme Court standards of patent-eligible subject matter). 
resource claims the greatest value might lie. ${ }^{295}$ The increasingly contested placement of patent law within property theory adds more difficulty, as property-based approaches to patent law are often viewed as a mere proxy for stronger substantive rights for patent owners, though in fact, property-based approaches can impose greater obligations on patent owners as well. ${ }^{296}$ Meanwhile, even within the patent-property framework, it is questionable whether the right level of notice that a patent (in its entirety) should provide is best measured by comparison merely to fences around land, rather than the correspondingly broad estate boundary of a real property interest. ${ }^{297}$

Fourth, and closely related to the problem of notice, is the problem of comparative institutional competence in evaluating a given patent right. When the Patent Office examines patent applications and generates a legal right in the form of a patent, the agency certainly has greater technological expertise, doctrinal familiarity, and policy experience than the generalist federal courts that are most likely to enforce or reevaluate the patent in the future. ${ }^{298}$ However, because courts have the last word on patent validity precisely as a check on agency decision-making, ${ }^{299}$

295. See Peter S. Menell \& Michael J. Meurer, Notice Failure and Notice Externalities, 5 J. LEGAL ANALYSIS 1, 13-14 (2013) (internal quotations omitted) (describing potential motivators and benefits for a claimant to frame his or her claims vaguely).

296. See Deepa Varadarajan, Of Fences and Definite Patent Boundaries, 18 VAND. J. ENT. \& TECH. L. 563, 594-95 (2016) ("Property-talk has helped expand the rights of patent holders, but it can also support erecting hurdles meant to improve the notice function of claims.").

297. See Adam Mossoff, The Trespass Fallacy in Patent Law, 65 Fta. L. REV. 1687, 1697-98 (2013) (cautioning against mistaken conceptual comparisons within the patent-property framework as the term property right encompasses a variety of legal rights).

298. See David L. Schwartz, Courting Specialization: An Empirical Study of Claim Construction Comparing Patent Litigation Before Federal District Courts and the International Trade Commission, 50 WM. \& MARY L. REV. 1699, 1701 (2009) ("Most district court judges are generalists who never hear enough patent cases to become experts in that area of law.").

299. This was, of course, much more the case before the ascendancy of administrative patent revocation, though the availability of judicial review remains a key justification for the constitutionality of the administrative system. See Oil States Energy Servs., LLC v. Greene's Energy Grp., LLC, 138 S. Ct. 1365, 1379 (2018) (analyzing the constitutionality of inter partes review). 
the value of the patent both as a legal right and as an economic asset can be quite uncertain when that value is based only on the actions of the Patent Office. ${ }^{300}$ Empirical estimates confirm this intuition, revealing that resolving uncertainty about the patent qua legal right "is worth as much on average as is the initial patent right." 301

The recent practices of the Patent Office have only added more fuel to these existing fires. The nature of panel stacking is necessarily to depart from the adjudicatory conclusion that a PTAB panel has already reached after evaluating the evidence and applying relevant legal principles to the technological facts of the case. ${ }^{302}$ It is, as the agency itself has conceded, a "case-specific readjudication" to vindicate other values that the agency's political leadership might find worthwhile. ${ }^{303}$ This case-by-case injection of political values into the validity and scope of property rights is a destabilizing force. Indeed, the more valuable the patent property right is, the more likely it is to be involved in litigation ${ }^{304}$ and, correspondingly, to be challenged in the PTAB. ${ }^{305}$ Meanwhile, the agency's attempts to broaden its nonappealable discretion push toward making it less and less accountable to independent judicial checks on its power.

Of course, not every such case-by-case judgment involving a property interest will necessarily cut against the property owner. A specific Patent Office administration may instead be quite

300. See Marco \& Vishnubhakat, supra note 285, at 104, 132 (discussing the effect of uncertainty about patent validity upon the value of patents).

301. Id. at 104.

302. See John M. Golden, PTO Panel Stacking: Unblessed by the Federal Circuit and Likely Unlawful, 104 IowA L. REv. 2447, 2449 (2019) ("[The] PTO Director and Director's delegee, the Chief Judge of the PTAB, have sometimes sought to reverse disfavored PTAB judgments by convening expanded panels of PTAB judges personally selected by the Director of Chief Judge to consider a request for rehearing - a practice commonly known as 'panel stacking.").

303. See Oral Argument at 47:20, supra note 39 (capturing testimony in which the Patent Office admits to panel stacking in order to push the Director's policy agenda).

304. See generally John R. Allison et al., Valuable Patents, 92 GEo. L.J. 435 (2004) (examining what makes a patent valuable and how to identify valuable patents).

305. Cf. George L. Priest \& Benjamin Klein, The Selection of Disputes for Litigation, 13 J. LEGAL STUD. 1 (1984) (analyzing the relationship between litigated disputes and disputes settled before or during litigation). 
protective of patent rights. If confronted with a PTAB panel judgment that invalidates some or all of a patent right, such an administration might see fit to stack the panel and preserve the property interest against cancellation. Even individual victories like this for the patent owner, however, are no less destabilizing to the patent right itself. These judgments, too, rest just as strongly on the problematic premise that the patent is not a legal right to be adjudicated in accordance with stable principles of neutral and general applicability-but instead is subject to the political priorities of agency decision-makers. ${ }^{306}$

In all, the politically inflected treatment of patents poses significant concerns about due process and other constitutional protections for property interests. ${ }^{307}$ It also compounds the problem of durability with which patent law already struggles, so that not only are doctrines of patent law flimsy and potentially fleeting but so also is the integrity of individual patent rights. ${ }^{308}$

306. This premise is problematic not only from the perspective of legal theory, but also economic theory insofar as economic actors will rationally avoid both dealing with an untrustworthy government and dealing with each other where the benefits of their productive exchanges may be expropriated. See Elizabeth Magill, Agency Self-Regulation, 77 GEO. WASH. L. REV. 859, 871 (2009)

Because government has a monopoly on the exercise of coercive powers, it has the authority . . . to take private assets . . . ignoring property and contracts rights in the process. But without stable property and contract rights, those with resources will not want to engage in financial dealings with the government ....

see also Jon ElsTER, Ulysses UnbOUND: STUDIES IN RATIONALITY, PRECOMmitMenT, AND ConstrainTs 1-77 (2000) (discussing constraint theory and why an individual may choose to engage in self-binding); Douglass C. North \& Barry R. Weingast, Constitutions and Commitment: The Evolution of Institutions Governing Public Choice in Seventeenth-Century England, $49 \mathrm{~J}$. ECON. HIST. 803, 803 (1989) ("The more likely it is that the sovereign will alter property rights for his or her own benefit, the lower the expected return from investment and the lower in turn the incentive to invest.").

307. See Adam Mossoff, The Use and Abuse of IP at the Birth of the Administrative State, 157 U. PA. L. REv. 2001, 2007-08 (2009) (discussing the conceptual shift in property theory that "made it possible for the administrative state to control and restrict various property uses without implicating the constitutional protections of the Takings or Due Process Clauses."); see also Adam Mossoff, Patents as Constitutional Private Property: The Historical Protection of Patents under the Takings Clause, 87 B.U. L. REv. 689, 693-711 (2007) (analyzing the history and intersection of patents, property, and constitutional private property).

308. See supra notes 293-294 and accompanying text (discussing how the 
In turn, the likely and rational result of destabilization in the legal integrity of patent property rights is for economic actors to seek other means for appropriating value from their investments. ${ }^{309}$ The main competitor of patent protection would be trade secrecy, and a turn to trade secrecy would directly contravene the patent system's aim of broader and faster dissemination of knowledge. ${ }^{310}$

\section{Injury to Credible Commitments}

The foregoing critique of imposing political valence on patent rights follows from a property-rights conception of patent law, but a property-based conception is not necessary to the critique. A view of patents as a form of regulation or public franchise rather than as a type of property ${ }^{311}$ also has much to reject about the

lack of durability in principles of patent law affects stable patent property rights and limits the value of a system premised on long term investment).

309. See Wesley M. Cohen, Richard R. Nelson \& John P. Walsh, Protecting Their Intellectual Assets: Appropriability Conditions and Why U.S. Manufacturing Firms Patent (or Not) 1 (Nat'l Bureau of Econ. Research, Working Paper No. 7552, 2000), https://perma.cc/M7DV-9P4R (PDF) ("In addition to the prevention of copying [a patent], the most prominent motives for patenting include the prevention of rivals from patenting related inventions (i.e., 'patent blocking'), the use of patents in negotiations and the prevention of suits.").

310. See Gideon Parchomovsky \& Peter Siegelman, Towards an Integrated Theory of Intellectual Property, 88 VA. L. REv. 1455, 1494 (2002) ("[P]atent protection is conditioned on full disclosure; trade secrecy rests on non-disclosure."); see also Rochelle Cooper Dreyfuss, Trade Secrets: How Well Should We Be Allowed to Hide Them? The Economic Espionage Act of 1996, 9 Fordham InTELl. Prop. MEDIA \& ENT. L.J. 1, 11 (1998) ("One way to think of the secrecy requirement in trade secrets law is as a substitute for the quality dimension of other laws - the novelty and nonobvious requirements of patent law, and the authorship and originality requirements of copyright law.").

311. Much has been written to debate whether patents are, indeed, property and should be treated accordingly. See, e.g., Varadarajan, supra note 296, at 573-75 (citing, inter alia, Eric R. Claeys, On Cowbells in Rock Anthems (and Property in IP): A Review of Justifying Intellectual Property, 49 SAN DIEGO L. REV. 1033, 1035 (2012)) (discussing the conflicting views between "property skeptics" and "property essentialists" which differ on whether to apply property terminology and rhetoric to patents); David Fagundes, Property Rhetoric and the Public Domain, 94 MinN. L. REv. 652, 652-57 (2010) (analyzing the importance of property rhetoric in the public domain); Frank H. Easterbrook, Intellectual Property Is Still Property, 13 HARV. J.L. \& PUB. POL'Y 108, 113 (1990) (stating the Intellectual Property Antitrust Protection Act of 1989 assimilated 
particular recent self-aggrandizements of the Patent Office. In this context, panel stacking and agency discretion that is broadly unreviewable by the courts undermines the ability of public institutions, including and especially the Patent Office itself, to make credible commitments to innovators and investors. ${ }^{312}$

Adherence to the legal principles of property is an example of credible commitments. ${ }^{313}$ However, because property rights, especially rights in private property, are vindicated primarily in the courts, ${ }^{314}$ a departure from property-centric views of patent law might suggest that a lack of robust judicial review is commensurately less problematic. As discussed below, there is reason to doubt this. ${ }^{315}$ Still, the broader problem of credible commitments is a distinct implication of the Patent Office's recent actions.

The theory of credible commitments may be summarized as holding that an institution can induce others to behave, and especially to invest, in desirable ways by voluntarily constraining

intellectual property to other property).

312. The literature on credible commitments derives primarily from new institutional economics. See generally Oliver E. Williamson, The Economic INSTITUTIONS OF CAPITALISM (1985) (applying transaction cost economics to economic organization, emphasizing behavioral assumptions of bounded rationality and opportunism); Douglass C. North, Institutions and Credible Commitment, 149 J. INSTITUTIONAL \& THEORETICAL ECON. 11 (1993) (examining the evolution of institutional theory while exploring how to develop institutions that provide credible commitments, enabling more complex contracting). It also has some counterpart in the political science literature on agency commitments but is, as Elizabeth Magill points out, concerned with a different set of questions. See Magill, supra note 306, at 872 n.40 (citing MURRAY HoRn, ThE Political Economy of Public Administration: Institutional Choice in the PUBLIC SECTOR 7-24 (1995)) (stating political scientists' primary argument on agency commitments is the creation of and delegation "to make a credible commitment to a constituency about the stability of policy in the future"). The discussion that follows draws primarily from the legal literature that applies credible commitment theory to the problems of administrative agency action.

313. See Douglass C. North, Institutions, Institutional Change and ECONOMIC PERFORMANCE 3 (1990) (providing adherence to the legal principles of property as an example of credible commitments).

314. See Maureen E. Brady, The Damaging's Clauses, 104 VA. L. REv 341, 409 (describing how inconsistencies in state interpretations of takings and damaging clauses "have the effect of preserving federal forums for vindicating federal property rights").

315. See infra Part III.C (discussing alternatives to judicial review). 
its own decisional power. ${ }^{316}$ In general, the relevance of credible commitments to executive action affects the President or the executive branch as a whole, whose actions vis-à-vis the coordinate branches of government, the public, or the market are being evaluated. ${ }^{317}$ In this context, where an executive agency is concerned, the commitment is that of the President to signal credibly the agency's future policy priorities by acting in certain ways including the appointment of the agency head. ${ }^{318}$ Indeed, as an agency itself answers variously to all three branches, it "does not even fully control its own destiny because those principals can force the agency to change its commitments." 319

That said, agencies do have some limited abilities to make credible commitments. According to what Thomas Merrill has called the Accardi principle, the discretion that an administrative agency might enjoy can be turned upon itself to bind its own future action. ${ }^{320}$ Under Accardi, an agency is obliged to follow its own duly promulgated regulations, and to act otherwise is contrary to law. 321 Thus, where no relevant regulation exists to bind the agency's hand, despite delegated authority for the agency to create it, one of two explanations is likely. The agency may value the flexibility of its own power more than it values the credibility of the commitments it can make to stakeholders. Or, if

316. See Daryl J. Levinson, Foreword: Looking for Power in Public Law, 130 HARV. L. REV. 31, 64-65 (2016) ("Constraints on decisional power can also generate credible commitments that induce others to behave in desirable ways. States and governments that can credibly commit to protecting property rights or repaying debts will benefit from economic investment and the ability to borrow on favorable terms ....").

317. E.g., Eric A. Posner \& Adrian Vermeule, The Credible Executive, 74 U. CHI. L. REV. 865, 865-68 (2007) (discussing the "the dilemma of credibility that afflicts the well-motivated executive" as both legislators and the public grant the executive discretion while still harboring distrust of the executive).

318. See id. at 900 (citing Nolan McCarty, The Appointments Dilemma, 48 AM. J. PolI. SCI. 413, 418-21 (2004)).

319. Magill, supra note 306, at 872.

320. See Thomas W. Merrill, The Accardi Principle, 74 Geo. Wash. L. Rev. 569,571 (2006) (describing the "[Supreme Court's] first full-fledged endorsement of the idea that agencies must follow their own regulations").

321. See United States ex rel. Accardi v. Shaughnessy, 347 U.S. 260, 266-67 (1954) (determining that the Board of Immigration Appeals is bound to exercise its own judgement prior to a final review by the Attorney General as dictated by the agency's regulation in question). 
the agency does, in fact, value the credibility of its proffered incentives more, it is simply acting irrationally.

Given the current posture of the Patent Office at the formative stages of the first robust adversarial system for administrative patent revocation, these two potential explanations are especially salient. If the use of panel stacking represents a deliberately muscular use of the agency's discretion (or at least of the discretion that the agency thinks it has), then the agency has been trading away its already limited ability to make credible commitments to induce investments in innovation. If that is not the result the agency wants, then it is not trading away the commitment mechanism but simply squandering it.

The push for broader unreviewable discretion is fraught with similar problems. Until 2005, agencies were even more robustly able to commit credibly to future courses of action. ${ }^{322}$ If a court held that a statute that the agency administered is unambiguous, with an accompanying interpretation of the statute by the court itself, then the stare decisis effect of that judicial interpretation would naturally bind the agency. ${ }^{323}$ Though this outcome would likely be disagreeable to the agency, it would at least lend credibility to the agency's promise to act according to the court's interpretation. ${ }^{324}$ If the agency wanted to seek that credibility proactively, it could interpret an ambiguous statute reasonably and secure a judicial holding approving the agency's interpretation based on Chevron deference. ${ }^{325}$ The binding interpretation would be the agency's own, but binding it would

322. See Jonathan Masur, Judicial Deference and the Credibility of Agency Commitments, 60 VAND. L. REV. 1021, 1024 (2007) (discussing how agency ability to shift policy and revise interpretations of ambiguous statutes with greater flexibility peaked in 2005).

323. See id. (comparing "if a court determines that a statue is unambiguous, the agency is entitled to no deference and thus no flexibility" to "if a statute is ambiguous, a court must afford deference to a valid agency interpretation and must allow the agency flexibility to adjust its interpretation over time").

324. See id. ("[S]tare decisis trumps Cheuron, in which case a pre-existing judicial decision would lock a statute's interpretation in place.").

325. See id. (summarizing how Chevron entitles an agency interpretation of an ambiguous statute deference). 
be. The stare decisis effect would be the same, as would the resulting credibility of the agency's promise. ${ }^{326}$

That changed after National Cable \& Telecommunications Association v. Brand $X$ Internet Services, ${ }^{327}$ in which the Supreme Court held that "[a] court's prior judicial construction of a statute trumps an agency construction otherwise entitled to Chevron deference only if the prior court decision holds that its construction follows from the unambiguous terms of the statute and thus leaves no room for agency discretion." 328 In other words, judicial findings about the meaning of ambiguous statutes could no longer enjoy stare decisis effect, and an agency could no longer rely on judicial entrenchment to make its own commitments credible. ${ }^{329}$

In light of this change, the sustained litigation agenda by the Patent Office to make its discretion in PTAB cases increasingly unreviewable is even more baffling. As with panel stacking, the relevant trade-off at hand is whether the agency values the flexibility of its discretion more than the credibility of its commitment to induce innovation through the incentive of stable, durable patent rights. ${ }^{330}$ Such an agenda might have been conceivable prior to Brand $X$ as a matter of longer-term agency policy, especially if the agency had not yet rendered a Cheuron-worthy interpretation. On that view, the agency today could exercise flexible discretion, and the option to seek Cheuron deference tomorrow would remain. ${ }^{331}$ However, after Brand $X$, pushing to expand unreviewable discretion only aggravates the

326. See id. (describing how stare decisis and Chevron deference both have precedential value).

327. 545 U.S. 967 (2005).

328. Id. at 982 .

329. See Masur, supra note 322, at 1036-37 (discussing the interaction between Cheuron and precedent after the Supreme Court's decision in Nat'l Cable \& Telecomms. Ass'n v. Brand X Internet Servs.).

330. See id. at 1024 ("[A]n agency will have difficulty convincing regulated parties to invest resources or take other actions that may well be critical to the success of a regulatory initiative when it cannot assure the private actor that the agency rule-upon which these investments depend-will remain in place....").

331. See id. at 1032 (citing Chevron itself that in such cases, courts "must allow the agency the flexibility to adjust its interpretation over time"). 
Patent Office's inability to look to judicial entrenchment as a source of credibility to back the agency's own assurances. ${ }^{332}$

The sum of these effects is, ironically, that the recent power-seeking acts of the Patent Office have the net effect of undermining the agency's power of persuasion to induce investments. ${ }^{333}$ Ultimately, it is this ability to make credible commitments that is at the heart of the agency's importance to innovation policy. To risk losing it is short-sighted and has the potential to inflict lasting harm on private decisions about resource allocation.

\section{Injury to Future Oversight}

Finally, beyond the present and potentially lasting harms that these Patent Office policies are likely to bring about within the tolerance of the agency's current judicial authorities, the future supervisory power of the courts is also at stake. The push for greater judicial unreviewability carves out an autonomous space for the PTAB to act without judicial scrutiny today, ${ }^{334}$ but it also forestalls correction by judicial powers to come.

This is significant because the early precedents in which the Federal Circuit endorsed the agency's burgeoning view of nonappealability could easily have gone the other way, providing for judicial review instead and frustrating the agency's attempts. By choosing not to do so, the Federal Circuit created a slippery slope where none existed, nor needed to.

The best indication of this counterfactual possibility is that, on a closely related statute, the precedents did go the other way. In Versata Development Group, Inc. v. SAP America, Inc., ${ }^{335}$ decided over a year after St. Jude and its companion cases and,

332. See John M. Golden, supra note 302 , at 2448 (assessing how in light of recent Supreme Court rejections of challenges to the constitutionality of proceedings reviewing the validity of issued patent claims, the Patent and Trademark Office will likely continue to be the leading trial forum for such proceedings).

333. See supra note 306 and accompanying text (summarizing how stability in patent property rights and incentives to invest are inversely related).

334. See supra Part III.A.2.

335. 793 F.3d 1306 (Fed. Cir. 2015). 
coincidentally, only a day after its panel decision in Cuozzo, the Federal Circuit held that in petitions for covered business method review, judicial review can be had over the PTAB's application of the definition of "business methods" that are eligible to be challenged. 336 The panel majority in Versata distinguished the facts of that case from those of Cuozzo, ${ }^{337}$ but it is also reasonable to infer that a different panel would reached the opposite conclusion in Cuozzo. For example, Judge Newman, who joined the panel majority in Versata, was also on the panel in Cuozzo and dissented there, arguing essentially the Versata majority opinion. ${ }^{338}$

The result, on balance, was a series of Federal Circuit appeals from the PTAB in which the deemed unavailability of judicial review suppressed important differences of opinion about the merits of Patent Office policy and procedure. For example, Judge Reyna in Shaw Industries joined the panel's opinion that the PTAB's refusal to grant review on a particular ground was judicially unreviewable under then-governing precedents. ${ }^{339}$ However, Judge Reyna also wrote separately to voice deep concern about the agency's extraordinary claim to autonomy from judicial oversight. ${ }^{340}$ In his view, the PTAB had been using that autonomy improperly, rejecting what it termed "redundant

336. See $i d$. at 1320 (discussing "the general presumption favoring judicial review" and how nothing in the statute in question precluded judicial review).

337. See id. at 1322 (stating Cuozzo did not address either of the issues the Court decided in concluding it may review whether the patent at bar is a covered business method patent).

338. Compare In re Cuozzo Speed Techs., LLC, 793 F.3d 1268, 1291 (Fed. Cir. 2015) (Newman, J., dissenting) (concluding the "America Invents Act was enacted to enable the [PTO] to resolve issues, at reduced cost and delay"), with Versata, 793 F.3d at 1321 (asserting "it is clear from the legislative history of the AIA that Congress purposely set out to create a relatively simple and expedited administrative process").

339. Shaw Indus. Grp., Inc. v. Automated Creel Sys., Inc., 817 F.3d 1293, 1297-98 (Fed. Cir. 2016) (citing both St. Jude, 749 F.3d at 1376, and Cuozzo, 793 F.3d at 1273) ("We lack jurisdiction, however, to review the Board's decisions instituting or denying [inter partes review] . . . This is true regardless of whether the Board has issued a final written decision.").

340. See id. at 1302 (Reyna, J., concurring) ("The Board's improper, conclusory statements declining to implement inter partes review ("IPR") of grounds it found to be "redundant" leave me deeply concerned about the broader impact that the Redundancy Doctrine may have on the integrity of the patent system."). 
grounds" without any explanation for how it was exercising its screening power. ${ }^{341}$ Unbound by earlier Federal Circuit precedents such as St. Jude or Cuozzo, these concerns would likely have counseled against such broad acceptance of judicial unreviewability. And, indeed, when the Federal Circuit sat en banc in Wi-Fi One to reconsider the unreviewability the one-year time bar, it was Judge Reyna who wrote for the 9-4 majority reversing Achates and imposing a principled limit on Patent Office autonomy. ${ }^{342}$

To some extent, this sort of path-dependence is an ordinary result of stare decisis and the purpose of generating binding precedent. ${ }^{343}$ However, when the jurisprudential issue at stake is judicial review itself, the stakes are different in kind. Wherever else the Federal Circuit might bind itself in agency appeals, particular care is needed on the issue of judicial review. Policing its own power of oversight is what keeps the Federal Circuit capable of policing the potential excesses of the Patent Office.

\section{Alternatives to Judicial Review}

Even when confronted with this account of benefits to the agency that are of dubious public value and of the grave systemic harms that are likely to result, one may reasonably ask whether judicial review is the only cure, or even the best cure. The Patent Office, after all, sits in the Department of Commerce and answers through to the Secretary of Commerce and the President. ${ }^{344}$ It

341. See id. ("[T]he [Patent Trial and Appeal] Board's only basis for not instituting the additional grounds was that those grounds are "redundant" of the instituted grounds, without any reasoned based why or how the denied grounds are redundant.").

342. See Wi-Fi One, LLC v. Broadcom Corp., 878 F.3d 1364, 1374 (Fed. Cir. 2018) (en banc) (stating "[e]nforcing statutory limits on an agency's authority to act is precisely the type of issue the courts have historically reviewed" and thus, time-bar determinations are reviewable).

343. See Oona A. Hathaway, Path Dependence in the Law: The Course and Pattern of Legal Change in a Common Law System, 86 IowA L. REv. 601, 602-05 (2001) (applying path dependence theory to the law to assess the influence of history in the United States' common law system).

344. See 35 U.S.C. $\S \S 1,2(b)(8)$ (2012) (stating the Patent and Trademark Office is within the Department of Commerce, subject to the policy discretion of 
also relies for its funds on the White House Office of Management and Budget ${ }^{345}$ and, ultimately, on Congress itself. ${ }^{346}$ These political principals exercise considerable influence over the agency. ${ }^{347}$ Thus, if the problem is that the agency is behaving in unduly political ways, an effective means of discipline might be to turn to these principals. ${ }^{348}$

However, there are notable problems with these political alternatives. For one thing, they give up the game on stable property interests in patent rights ${ }^{349}$ and, to the same extent, do little to resolve the due process concerns involved. ${ }^{350}$ The result is not only an entrenchment of incumbent political interests that have access to the public powers that oversee the Patent Office. It is also, more perniciously, an entrenchment of incumbent economic interests in the market, incumbency that could be disrupted in socially valuable ways by new entrants armed with patents. ${ }^{351}$ Judicial review, though it also often favors well-resourced litigants as an empirical matter, does not base its

the Secretary of Commerce, and shall advise the President, through the Secretary of Commerce, on intellectual property issues).

345. See id. §3(a)(2)(B) (requiring the Director to consult with the Patent and Trademark Public Advisory Committees, respectively and applicably, before submitting budget proposals to the Office of Management and Budget).

346. See id. $\S 42(\mathrm{e})$ (requiring the Secretary of Commerce to submit the Patent and Trademark Office's fiscal reports and proposed budget to Congress).

347. See Giulio Napolitano, Conflicts and Strategies in Administrative Law, 12 INT'L J. OF CONST. L. 357, 360 (2014) (discussing Congress' structural and procedural control over agencies in order to channel and monitor future bureaucratic action).

348. See id. (“Stacking the deck' in favor of certain groups, removing some decisions from the choice set, requiring or forbidding an agency to consider certain issues, and placing the burden of proof on an agency ... are among the most preferred devices [of congressional control].").

349. See supra Part III.B.2.

350. See supra Part III.B.1.

351. See Sean M. O'Connor, Crowdfunding's Impact on Start-Up IP Strategy, 21 GEO. MASON L. REV. 895, 900 (2014) ("Patents allow start-ups to appropriate the value of their [research and development] results by giving them legally enforceable exclusive rights that can be exercised against large incumbents seeking to copy the start-ups' innovations."); Stephen H. Haber, F. Scott Kieff \& Troy A. Paredes, On the Importance to Economic Success of Property Rights in Finance and Innovation, 26 WASH. U. J.L. \& POL'Y 215, 222 (2008) ("[P]atents are powerful antimonopoly weapons-the vital slingshots "Davids" use to take on "Goliaths."). 
substantive judgments about the correctness of a position on the political or economic status of the litigant. 352

Another difficulty is that these alternatives for correcting undesirable Patent Office action risk the appearance of injecting politics into an apolitical process. Although panel stacking in the PTAB and the arguments for broader unreviewability of the PTAB advance priorities that are unrelated to the PTAB's adjudicatory mandate, these agency actions have nevertheless been carried out under the guise of, and through the apparatus of, adjudication. ${ }^{353}$ Overt political means of agency discipline such as a mandate from a higher executive power or budgetary leverage from Congress would likely be received as an escalation by the Patent Office and, although it might resolve the immediate grievance in the PTAB, would be unlikely to change the agency's long-term behavior with respect to the underlying structural problems discussed here.

Finally, perhaps the most pedestrian and formally legal reason against abjuring judicial review is also the most fundamental: it has been central to justifying the PTAB's very existence. The Supreme Court concluded recently in Oil States Energy Services, LLC v. Greene's Energy Group, $L L C^{354}$ that the system of inter partes review that Congress established in the AIA is, indeed, constitutional. ${ }^{355}$ Among the key attributes of PTAB review to which the Court pointed in emphasizing "the narrowness of [its] holding" was that "the Patent Act provides for judicial review by the Federal Circuit." ${ }^{356}$ As a result, the Court expressly avoided the question "whether inter partes review would be constitutional without any sort of intervention by a

352. See Albert Yoon, The Importance of Litigant Wealth, 59 DEPAUL UNIV. L. REv 649, 649-52 (2010) (discussing the relationship between litigant wealth and litigation outcomes while addressing the neutral role the court must play).

353. See John M. Golden, supra note 302, at 2464 ("[PTO] panel stacking is a reasonable way for the PTO Director to oversee [PTAB] adjudication where Congress has failed to give the Director a more conventional mechanism for doing so ....").

354. 138 S. Ct. 1365 (2018).

355. Id. at 1379 (affirming the Court of Appeals' reasoning that inter partes review does not violate Article III or the Seventh Amendment).

356. See id. (citing 35 U.S.C. $§ 319$ (2012)) (“[T]he Patent Act provides for judicial review by the Federal Circuit ...."). 
court at any stage of the proceedings." 357 In short, judicial review was a significant element of the set of sufficient conditions that underlay the constitutional legitimacy of $\mathrm{PTAB}$ review as currently structured. The erosion of that review by the Patent Office itself, therefore, stands to erode the very foundation on which the agency's system of administrative patent revocation rests.

\section{Sources of Agency Aggrandizement}

Part III discussed the benefits that have motivated the Patent Office in the aggrandizements detailed in Part II, the resulting systemic harms, and the continuing superiority of judicial review over other means for ensuring agency discipline. This Part reveals the origin story, explaining why the Patent Office colorably thought itself empowered to act as it has. That exercising the patent validity power ex post was once almost exclusively the province of the courts, but is now increasingly and conspicuously the province of the Patent Office, is well documented. ${ }^{358}$

However, as Part IV.A explains, the reasoning behind this reallocation has traditionally been an account of greater expertise, lower cost, and more accurate outcomes in the specialized agency setting than the courts would have offered. To that traditional account Part IV.B adds a largely neglected rationale: a desire for greater political input in the patent system. Part IV.C then takes that generalized desire for political input, which Congress itself shared and implemented in certain discrete domains, and delves into the actual decisional structure of the

357. See id. (citing Atlas Roofing Co. v. Occupational Safety \& Health Review Comm'n, 430 U.S. 442, 445 (1977)) (“[W]e need not consider whether inter partes review would be constitutional 'without any sort of intervention by a court at any stage of the proceedings."').

358. See Strategic Decision Making, supra note 8, at 78-81 (discussing how the Patent Office assesses and decides invalidity petitions while the federal courts manage patent infringement litigation which the aforementioned petitions impact); see also Youngest Patent Validity Proceeding, supra note 118, at 345-47 (addressing ex post review up to the America Invents Act); Mark D. Janis, Rethinking Reexamination: Toward a Viable Administrative Revocation System for U.S. Patent Law, 11 HARV. J.L. \& TECH. 1, 3-7 (1997) (discussing the role of the Patent and Trademark Office in American patent law jurisprudence). 
PTAB, showing that the agency has consciously commingled two separately delegated powers in a bid to obscure its remarkable claims to power that Congress did not give.

\section{A. The Traditional Account: Expertise}

When Congress was considering what would become the first transfer of the patent validity power from Article III courts to the Patent Office, the typical posture for reviewing patent validity had been as a defense in infringement litigation ${ }^{359}$ or, somewhat less commonly, as a claim for declaratory judgment that the patent was invalid. ${ }^{360}$ The motivations for an administrative alternative were primarily of institutional competence. ${ }^{361}$ The considerable cost and delay of patent litigation, constrained access from Article III standing requirements, and the accuracy of the decisions that courts produce were all matters of concern. ${ }^{362}$ Although the extent and effect of these concerns is undoubtedly greater today, ${ }^{363}$ cost and delay were deeply felt even when Congress was considering enacting ex parte re-examination. ${ }^{364}$

359. See 35 U.S.C. $\S 282(\mathrm{~b})(2)$ (2018) (providing that "[i]nvalidity of the patent or any claim in suit on any ground specified in part II as a condition for patentability" shall be a defense to infringement).

360. See 28 U.S.C. $§ 2201$ (a) (authorizing any court of the United States to "declare the rights and other legal relations of any interested party seeking such declaration, whether or not further relief is or could be sought"); see also Walker Process Equip., Inc. v. Food Mach. \& Chem. Corp., 382 U.S. 172, 176 (1965) (noting that "one need not await the filing of a threatened suit by the patentee; the validity of the patent may be tested under the Declaratory Judgment Act").

361. See Strategic Decision Making, supra note 8, at 51-55 (discussing motivations for administrative rather than judicial review of patent validity).

362. See id. (summarizing the interrelated arguments in favor of administrative review).

363. See Saurabh Vishnubhakat, What Patent Attorney Fee Awards Really Look Like, 63 DuKE L.J. ONLINE 15, 18 (2014) (summarizing the cost of patent infringement litigation across different tiers of disputed value based on data from the American Intellectual Property Law Association's biennial Report of the Economic Survey).

364. See H.R. Rep. No. 96-1307, pt. I, at 3-4 (1980) (emphasizing the potential for administrative review to resolve patent validity questions "without recourse to expensive and lengthy infringement litigation"). 
So was accuracy. Contemporary empirical research suggests that the federal courts may not be particularly accurate on questions of patent validity, ${ }^{365}$ such as the proper interpretation of terms within patents. ${ }^{366}$ Longitudinal research also suggests that judges with experience specific to patent law are less likely to suffer reversal on appeal and that is true of recent as well as cumulative patent experience. ${ }^{367}$ However, though this research may tend to vindicate historical efforts to transfer power away from a generalist court toward an expert agency, the contemporaneous desire in 1980 for more accurate patent case decisions was different in a subtle, but important way that reveals much about the power transfer itself.

Rather than imagining the court as a unitary decision maker that could be beneficially supplanted by an agency decision maker, makers of patent policy in the late 1970 s and early 1980 s were quite sensitive to how the validity power was shared, within a court, between judges and juries. ${ }^{368}$ There was robust disagreement on whether a jury was the right audience for patent validity issues of both scientific and legal complexity, but the controversy was not about accuracy as such. ${ }^{369}$ Judges tended to agree that in reaching accurate decisions, the best that a jury

365. See generally Anup Malani \& Jonathan S. Masur, Raising the Stakes in Patent Cases, 101 GEO. L.J. 637 (2013) (discussing proposals to improve accuracy in the resolution of patent disputes).

366. See, e.g., David L. Schwartz, Practice Makes Perfect? An Empirical Study of Claim Construction Reversal Rates in Patent Cases, 107 MiCH. L. REV. $223,248-49$ (2008) (identifying rates of reversal due to improperly construed terms).

367. See Jay P. Kesan \& Gwendolyn G. Ball, Judicial Experience and the Efficiency and Accuracy of Patent Adjudication: An Empirical Analysis of the Case for a Specialized Patent Trial Court, 24 HaRv. J.L. \& TECH. 393, 443-44 (2011) (discussing empirical research on the effects of judicial experience on rates of reversal).

368. See, e.g., The Seventh Annual Judicial Conference of the United States Court of Customs and Patent Appeals, 88 F.R.D. 369, 387 (1980) [hereinafter Seventh CCPA Conf.] (providing personal observations of the Hon. Frank J. McGarr).

369. See, e.g., The Eighth Annual Judicial Conference of the United States Court of Customs and Patent Appeals, 92 F.R.D. 183, 275-77 (1981) [hereinafter Eighth CCPA Conf.] (preserving on record anecdotes from judges in attendance). While some judges agreed that juries could follow most cases, others found certain issues too complex for the average juror to understand. 
could do was as well as a judge, ${ }^{370}$ and quite often the jury was likely to make mistakes. ${ }^{371}$ The source of mistake might have been that juries are suggestible to clever lawyering, that they depart from evidence or judicial instruction, or simply that they lack scientific or legal literacy. ${ }^{372}$ At all events, these were utilitarian concerns.

The argument in favor of jury trials in patent cases, meanwhile, was based on constitutional principle. ${ }^{373}$ Whatever the wisdom of jury trials in patent cases, the Seventh Amendment required it. ${ }^{374}$ Put another way, the jury right in patent cases was not welcomed because it produced accuracy; it was tolerated because it was, higher courts had said, constitutionally necessary. The real policy debate was about power.

The agenda to shift power from courts, particularly juries, on patent validity issues and into the Patent Office had one particularly persuasive aspect. The problems of cost, delay, and accuracy insofar as juries were concerned were still relatively. new. ${ }^{375}$ Only twenty years earlier had the Supreme Court set the

370. For example, of the Hon. William C. Conner suggested in his remarks with that "the jury is usually right. At least they make the same mistakes as judges." Id. at 276.

371. See Seventh CCPA Conf., supra note 368 , at 387 (listing remarks by the Hon. Frank J. McGarr opining that "juries have complicated the patent litigation situation, and I don't think they have contributed to the end product we all seek, which is the doing of justice and the achieving of the right result").

372. See id. (enumerating the pitfalls encountered by jurors in complex patent litigation).

373. Judge McGarr, just before his criticism of jury decision-making, stated the tension plainly:

I would not say ... that I am hostile to the jury idea in patent cases.

You have to be careful how you say this because the jury right is a very genuine one, and attorneys should have a right to a jury if the court says that juries are available in patent cases, and it sounds like the judge is arrogating unto himself the total power of decision ....

Id. at 386 .

374. See generally Tights, Inc. v. Stanley, 441 F.2d 336, 344 (4th Cir. 1971) (issuing a writ of mandamus directing the district court to allow demands for jury trials on patent validity as well as infringement because the Seventh Amendment jury trial right applied to patent cases and was not lost by combining legal claims for damages with equitable claims for injunctive relief).

375. See infra note 380 and accompanying text (demonstrating that jury 
constitutional premise requiring patent validity to be tried to juries. ${ }^{376}$ In Beacon Theatres, Inc. $v$. Westover, ${ }^{377}$ the Court held that where a case presents both legal issues (such as a claim for damages) and equitable issues (such as a claim for injunction), the right to have the legal issues tried to a jury cannot be lost by deciding the equitable issues first in a bench trial. ${ }^{378}$

Before Beacon Theatres, that loss of jury trial would not only have been doctrinally ordinary but also empirically rare. ${ }^{379}$ As Figure One shows, among patent trials annually, fewer than a handful were tried to juries in the years preceding Beacon Theatres. ${ }^{380}$ Where a jury trial was demanded, judges first tried equitable claims and then allowed the jury to try whatever legal claims remained. ${ }^{381}$ At that point, the loser in equity was, due to collateral estoppel, unable to reargue the lost issues to the jury, including the issue of patent validity. ${ }^{382}$ Once it became clear that the holding in Beacon Theatres applied to patent cases, ${ }^{383}$ a case with a jury demand had to be put to the jury first. The share of patent cases that were tried to juries began to rise, and although many a judge tried "to make everything a legal issue he can make

trials were empirically rare, and the associated costs had yet to be realized).

376. See Beacon Theaters, Inc. v. Westover, 359 U.S. 500, 508 (1959) (designating the trial court's use of discretion under Fed. R. Civ. P. 42(b) to deprive a party of a full jury trial impermissible).

377. Id.

378. See id. at 501-11 ("[O]nly under the most imperative circumstances . . can the right to a jury trial of legal issues be lost through prior determination of equitable claims.").

379. See infra note 380 and accompanying text (charting the percentage increase of patent jury trials).

380. Figure 1, found in the Appendix, is reproduced from J. Jonas Anderson \& Peter S. Menell, Informal Deference: A Historical, Empirical, and Normative Analysis of Patent Claim Construction, 108 Nw. U. L. REV. 1, 20 (2013). I am grateful to Professors Anderson and Menell for sharing the underlying data that they compiled from separate sources.

381. See Mark A. Lemley, Why Do Juries Decide If Patents Are Valid?, 99 VA. L. REV. 1673, 1706 (2013) (noting how the common practice of holding jury trials only after bench trials explained the small number of patent jury trials in the decades before Beacon Theaters).

382. Id. (citing Ralph W. Launius, Some Aspects of the Right to Trial by Jury in Patent Cases, 49 J. PA'T. OFF. Soc'Y 112, 112-13 (1967)).

383. See Tights, 441 F.2d at 338, 343 (recognizing the right to submit legal issues to a jury notwithstanding the complexity of patent cases). 
a legal issue to minimize submission to the jury," 384 there was an appetite to roll back more systematically the larger problem of juries reviewing technical questions of patent validity.

The resulting system for ex parte reexamination was only the start. In the American Inventors Protection Act of $1999,{ }^{385}$ a new system for inter partes reexamination offered yet another alternative for litigants to leave courts and seek review in the Patent Office. ${ }^{386}$ The issues of court-agency power that these first- and second-generation administrative proceedings raised bear a striking resemblance to the current controversies over patent validity review under the AIA. ${ }^{387}$ Foremost among these were two issues, the substitutability of the Patent Office for district courts in reevaluating patents and the contours of judicial review over the Patent Office. ${ }^{388}$ In order to appreciate these two issues more fully, however, it is first necessary to identify a less widely appreciated rationale for transferring ex post power over patent validity away from courts and into the agency.

\section{B. The Neglected Rationale: Political Input}

That rationale is a desire to seek greater political input into the patent system. On first impression, the notion of imbuing a system of property rights with political salience is peculiar. Well-functioning property rights regimes tend to arise from legal structures that reflect certainty and durability ${ }^{389}$-rarely the

384. Seventh CCPA Conf., supra note 368, at 385.

385. American Inventors Protection Act of 1999, Pub. L. No. 106-113, 113 Stat. 1501.

386. See id. (giving the PTO some authority to conduct inter partes adjudicatory proceedings).

387. See generally Clarisa Long, The PTO and the Market for Influence in Patent Law, 157 U. PA. L. REv. 1965 (2009) (discussing the evolution of the PTO's administrative influence compared to that of the judicial branch).

388. See id. at 1975 (discussing increased judicial deference to the PTO's findings); see also Arti K. Rai, Patent Validity Across the Executive Branch: Ex Ante Foundations for Policy Development, 61 DUKE L.J. 1237, 1239 (2012) (noting the resemblance of post-grant review proceedings to formal adjudications).

389. See John F. Duffy, Rules and Standards on the Forefront of Patentability, 51 WM. \& MARY L. REV. 609, 610-11 (2009) (highlighting the 
stuff of politics. Nevertheless, persistent themes in the patent literature and across multiple domains of patent policy reveal a view that patents should be treated as a species of regulation or monopoly privilege rather than property, ${ }^{390}$ that patent law should be regarded as public rather than private law, ${ }^{391}$ and that the patent system should be approached essentially as a field of industrial policy. ${ }^{392}$ These views are systematically political and exert considerable pressure against traditional accounts of patents as private property rights that are best mediated by

necessity of "certainty" to well-functioning property rights; see also Craig Allen Nard, Certainty, Fence Building, and the Useful Arts, 74 IND. L.J. 759, 759 (1999) (articulating the benefits of propriety certainty).

390. For scholarship discussing this tension and its effects, see Adam Mossoff, Exclusion and Exclusive Use in Patent Law, 22 HARV. J.L. \& TECH. 321, 370-77 (2009) (analyzing the role of conceptual property theory in patent law); Mark A. Lemley, Property, Intellectual Property, and Free Riding, 83 Tex. L. REV. 1031, 1035 n.8 (2005) (identifying a dichotomy within intellectual property theory); Einer Elhauge, Defining Better Monopolization Standards, 56 STAN. L. REV. 253, 304-05 (2003) (discussing whether patents should be considered a form of monopoly or more akin to the traditional property right of exclusion); Herbert Hovenkamp, Patents, Property, and Competition Policy, 34 J. CoRP. L. 1243, 1243 (2009) (considering whether competition policy should have a more prominent role in the patent system).

391. See, e.g., Megan M. La Belle, Patent Law as Public Law, 20 Geo. Mason L. REV. 41, 43 (2012) (stating that "patent validity challenges are complaints about government conduct that implicate important public interests and potentially affect many parties not before the court"); Megan M. La Belle, Public Enforcement of Patent Law, 96 B.U. L. REV. 1865, 1866 (2016) (proposing an enforcement scheme for patent law); Ted Sichelman, Purging Patent Law of "Private Law" Remedies, 92 TEx. L. REv. 517, 517 (2014) (rejecting the private remediation of infringement as antithetical to the "overarching aim" of patent law); Sapna Kumar, Standing Against Bad Patents, 32 BERKELEY TECH. L.J. 87, 87 (2017) (discussing use of standing jurisprudence to hinder challenges to bad patents before the PTAB).

392. See Kenneth W. Dam, The Economic Underpinnings of Patent Law, 23 J. LEGAL STUD. 247, 248 (1994) (positing that the economic policy behind patent law can be thought of as industrial policy "because it uses legal intervention to decide what policies to promote"); see also Michael H. Davis, Patent Politics, 56 S.C. L. REV. 337, 339-40 (2004) (describing patent law as "a kind of disguised industrial policy"); Oskar Liivak, Maturing Patent Theory from Industrial Policy to Intellectual Property, 86 TUL. L. REv. 1163, 1165 (2012) (classifying patent law as industrial policy rather than a theory of property); Allen K. Yu, Within Subject Matter Eligibility-A Disease and a Cure, 84 S. CAL. L. REv. 387, 388 (2011) (emphasizing "the importance of viewing the patent regime not just as a property system, but as part of a larger regulatory regime for promoting innovations"). 
market ordering. ${ }^{393}$ As a result of these pressures, reallocations of the ex post patent validity power away from courts and into the Patent Office now also have a clear political valence. ${ }^{394}$

To understand the politicization of ex post patent validity, it is helpful first to clarify what it does not represent. For one thing, it is not merely a more specific recapitulation of post-realist attitudes about the malleability of property rights more generally. ${ }^{395}$ Nor is it a systematic remaking of the Patent Office into a more formally participatory and deliberative agency-a "surrogate political process" 396 similar to that of the Environmental Protection Agency-as scholars including James Boyle $^{397}$ and Kali Murray ${ }^{398}$ have advocated.

Instead, the move of ex post patent validity toward a political sphere has come in a more piecemeal fashion. A direct mechanism for the change has been the specific way in which the patent validity power was reallocated away from courts and to political authorities within the Patent Office. ${ }^{399}$ Another, more indirect, has been the emergence of technology- and industry-specific laws and policies pertaining to patentability and patent validity. Taken together, these mechanisms have produced ex post a trend similar to what Arti Rai has described and

393. See Lemley, supra note 390, at 1032 (noting the similarities between the "Protectionist" regime for intellectual property and traditional private property theory).

394. See infra notes 399-400 (explaining the politicization of patent validity decisions).

395. See Arti K. Rai, Competing with the "Patent Court": A Newly Robust Ecosystem, 13 CHI.-KENT J. INTELL. PROP. 386, 386-87 (2014) (comparing historical accounts that liken patents to inviolable tangible property with modern views); see also Mossoff, supra note 307, at 2013 (discussing the role of intellectual property theory in redefining property in land).

396. Richard B. Stewart, The Reformation of American Administrative Law, 88 HARV. L. REV. 1667, 1670 (1975).

397. See James Boyle, A Politics of Intellectual Property: Environmentalism for the Net?, 47 DUKE L.J. 87, 87 (1997) (exploring a theoretical "political economy" of intellectual property) .

398. See Kali N. Murray, Rules for Radicals: A Politics of Patent Law, $14 \mathrm{~J}$. INTELL. PROP. L. 63, 64 (2006) (using environmental law as a comparative model to conceptualize a world of politically-molded patent law).

399. See Rai, supra note 388, at 1238-39 (identifying the ways in which the PTO has increased its influence within patent policy). 
advocated with regard to ex ante decision-making by political actors about patent validity. 400

\section{Empowering the Agency's Political Leadership}

From the start, administrative exercise of the patent validity power has been divided. The eventual determination of validity has been made by an administrative adjudicator. In ex parte and inter partes reexaminations, that has been the reexaminer. ${ }^{401}$ In AIA reviews, it has been a panel of at least three administrative patent judges. ${ }^{402}$ Prior to consideration of the merits, however, petitions for each type of administrative proceeding have always been screened to ensure that expending resources to reconsider patent validity would not be a waste. 403

In ex parte and inter partes reexamination, the legal standard for this screening was to identify a "substantial new question of patentability." 404 Now in inter partes review, covered business method review, and post-grant review under the AIA, the standard is a sufficient likelihood that the proceeding will successfully invalidate at least one claim in the challenged patent. 405 Covered business method and post-grant reviews' screening criteria can be separately satisfied if "the petition raises a novel or unsettled legal question that is important to

400. See id. at 1244 (positing "whether the PTO should be given rulemaking authority over substantive patent law ....").

401. See U.S. Patent and Trademark Office, Manual of Patent EXAMINING PROCEDURE $\S \S 2253,2656$ (9th ed. 2018) (designating Examiner to determine validity in ex parte and inter partes reexamination).

402. See 35 U.S.C. $\S \S 6(b)(4)$, (c) (2012) (requiring review by a three-member panel).

403. See infra notes 404-414 (identifying varying levels of screening requirements).

404. 35 U.S.C. $\S 303$; see U.S. Patent AND TRADEMARK OFFICE, supra note 401 , at $\S 2216$ (stating the screening standard for ex parte reexamination); 35 U.S.C. § 312; see also U.S. PATENT AND TRADEMARK OFFICE, supra note 401, at $\S 2616$ (stating the screening standard for inter partes reexamination).

405. The standard for IPR is a "reasonable likelihood" of success. 35 U.S.C. $\S 314(\mathrm{a})$. Meanwhile, the standard for CBM and PGR is that success is "more likely than not." Id. § 324(a); see also Leahy-Smith America Invents Act, Pub. L. No. 112-29, § 18(a)(1), 125 Stat. 284 (2011) (subjecting proceedings implemented pursuant to the transitional program for covered business method patents to the same standards and procedures of a post grant review). 
other patents or patent applications." ${ }^{406}$ Ex parte reexamination, moreover, does not require a third party to seek review: the agency may open review of the validity of an issued patent on its own initiative and at any time. 407

In all of these administrative proceedings, the power to carry out the screening rests with the political head of the agency. 408 Since 2000, that has been the Director of the Patent and Trademark Office, a position that is also styled the Under Secretary of Commerce for Intellectual Property. ${ }^{409}$ Prior to 2001, the relevant political head was the Commissioner of Patents, and the ex parte reexamination statute referred to that position accordingly. ${ }^{410}$

This repeated investment of the screening power in the political, rather than adjudicatory, structure of the Patent Office is significant. The widely recited justification for administrative adjudication is that the agency has a comparative advantage in scientific expertise; ${ }^{411}$ this, in turn, is said to lower costs, expedite resolutions, and ultimately produce more accurate decisions. ${ }^{412}$

406. 35 U.S.C. $\S 324(\mathrm{~b})$; see also Leahy-Smith America Invents Act $§ 18(a)(1)$ (using the same standards and procedures of post-grant review for covered business method patents).

407. See 35 U.S.C. § 303(a) ("On his own initiative, and any time, the Director may determine whether a substantial new question of patentability is raised ...."); 37 C.F.R. $§ 1.520$ (2019) (authorizing ex parte reexamination at the initiative of the director); see also U.S. PATENT AND TRADEMARK OFFICE, supra note 401 , at $\S 2239$ (vesting discretion in the director to order reexamination even in the absence of a request by the parties).

408. See 35 U.S.C. $\S \S 303(a), 314(a), 324(a)$ (discussing when the director may authorize review or determine that a substantial new question of patentability exists).

409. See AIPA, Pub. L. No. 106-113, app. I § 4713, 113 Stat. 1501 (codified as amended at 35 U.S.C. $\S 3$ (a) (2000)) ("The powers and duties of the United States Patent and Trademark Office shall be vested in an Under Secretary of Commerce for Intellectual Property and Director of the United States Patent and Trademark Office .....").

410. See 35 U.S.C. $§ 303$ (a) (1982) (designating Commissioner to make the determination whether a substantial new question of patentability is raised).

411. See Strategic Decision Making, supra note 8, at 53 (quoting 35 U.S.C. $\S 6$ (2018)) ("In contrast [to federal judges], administrative patent judges have long been required to be "persons of competent legal knowledge and scientific ability."').

412. See id. at 52-54 (discussing arguments in favor of administrative review). 
Placing a political filter at the threshold of the process, however, undermines the presumed procedural neutrality of technical expertise. This effect is especially stark for ex parte reexamination, where the political agency head, who already holds the keys to review, may open the gates on his own initiative with no need to wait (as federal courts must wait) for private parties to initiate a case. ${ }^{413}$ It is questionable whether apolitical impartiality should be sacrificed in exchange for technical expertise in this way.

Even if the benefits of such a tradeoff outweighed the costs, however, it seems clear that judicial review of the agency's screening would be needed to ensure that a political head's exercise of threshold power was not unduly distorting the substantive agency adjudications that follow. But this is not the case, either. The Director's screening decision has been "final and nonappealable" in every iteration of administrative validity review, starting with ex parte reexamination, ${ }^{414}$ continuing with inter partes reexamination, ${ }^{415}$ and now in the AIA proceedings. ${ }^{416}$ The details of this nonreviewability have changed in important ways, moreover, from reexamination to the AIA proceedings. ${ }^{417}$

\section{Making Technology-and Industry-Specific Policy}

Although conferring judicially unreviewable power upon Patent Office leadership to screen requests for patent reevaluation is the most direct injection of politics into how the validity power is exercised, it is not the only one. The agency has also become receptive to ex post political input into patent validity

413. See supra note 407 and accompanying text (explaining the authorization of ex parte reexamination at the director's discretion).

414. 35 U.S.C. $\S 303(c)$ (1982); 35 U.S.C. $\S 303(c)$ (1988); 35 U.S.C. $\S 303(\mathrm{c})$ (1994); 35 U.S.C. $\S 303(c)(2000) ; 35$ U.S.C. $\S 303(c)(2006) ; 35$ U.S.C. $\S 303(c)$ (2018).

415. 35 U.S.C. $\S 312(c)(2000) ; 35$ U.S.C. $\S 312$ (c) (2006); 35 U.S.C. $\S 314(d)$ (2018).

416. See 35 U.S.C. $\S \S 314(d), 324(\mathrm{e})$ (2018) (prohibiting appeal for inter partes and post-grant review).

417. See infra notes 470-475 and accompanying text (discussing the presumptive reviewability of subsequent adjudication). 
through indirect interventions in patent law and policy. ${ }^{418}$ The common thread in these laws and policies is that they are specific to certain technologies and industries. 419

To be clear, the particular trend of tailoring patent law and policy by technology and industry, like the politicization of patent validity more generally, is a broad and complex phenomenon with a variety of structural implications for the patent system. ${ }^{420}$ The enacted law of patents is a set of broad, unitary standards that are theoretically context-neutral, ${ }^{421}$ but these standards can operate quite differently in practice and application across technologies and industries. ${ }^{422}$ This much is straightforward, even self-evident. ${ }^{423}$ More politically salient, however, is the argument that law- and policy-makers, primarily courts, should take conscious account of these disparities and should try to tailor patent protection to perceived economic goals and exigencies. ${ }^{424}$

This argument is even more politically salient when the institution involved is not the judiciary, but the Patent Office. The reason to meet technology and industry needs through

418. See Dan L. Burk \& Mark A. Lemley, Policy Levers in Patent Law, 89 VA. L. REV. 1575, 1586-87 (2003) [hereinafter Policy Levers] (remarking on government-created incentives for research and development).

419. See id. at 1587 ("[T] varies by industry.").

420. See Dan L. Burk \& Mark A. Lemley, Is Patent Law Technology-Specific?, 17 BERKELEY TECH. L.J. 1155, 1155-57 (2002) [hereinafter Is Patent Law Technology-Specific?] (reflecting on the implications of applying technology- and industry-specific rather than neutral standards).

421. See Saurabh Vishnubhakat, Expired Patents, 64 CATH. U. L. REV. 419, 420-26 (2015) (discussing technology-specificity in patenting); see also NAT'L RESEARCH COUNCIL OF THE NAT'L ACADS., A PATENT System FOR THE 21ST CENTURY 42 (Stephen A. Merrill et al. eds., 2004) ("[The patent system] is a unitary system with few a priori exclusions.").

422. See Mark D. Janis, Comment: Equilibrium in a Technology-Specific Patent System, 54 CASE W. RES. L. REV. 743, 743-44 (2004) (expressing reservations concerning the feasibility of equilibrium in patent law); see also Is Patent Law Technology-Specific?, supra note 420, at 1156 (commenting on the inconsistency of rule application across different industries).

423. See Janis, supra note 422 , at 743 n.2 ("Or, to put it more succinctly, 'duh."').

424. See Policy Levers, supra note 418 , at 1579 (noting the substantial latitude courts possess to "[adapt] the patent statute to evolving technologies"). 
judicial tailoring rather than, say, legislative tailoring is that the legislative process invites rent seeking and fails to adapt quickly enough to innovation. ${ }^{425}$ Legislative tailoring also produces balkanized legal regimes and requires costly litigation to resolve boundary line-drawing issues between adjacent regimes. ${ }^{426}$ Tailoring by courts, for all its flaws, ${ }^{427}$ is likely to be more responsive and less prone to capture than sector-specific legislation. ${ }^{428}$

Thus, reallocating technology- and industry-specific ex post patent validity judgments out of the courts and into the Patent Office represents not one, but two political moves. One is the very act of actively tailoring patent protection in service of economic policy goals rather than merely recognizing that such effects may come about naturally in different fact contexts. The other is the placement of this tailoring with an agency that is itself a target for efforts at rent seeking and capture. ${ }^{429}$

425. Id. at 1578 .

426. See Janis, supra note 422 , at 745 (considering whether numerous boundary issues would inundate the dockets of even the most skilled patent judges).

427. See Rai, supra note 388 , at 1242-43 (listing the drawbacks of article III adjudication).

428. See Policy Levers, supra note 418, at 1578-79 ("[C]oncerns about ... the inability of industry-specific statutes to respond to changing circumstances will lead us to conclude...that we should not jettison our nominally uniform patent system in favor of specific statutes that protect particular industries."); see also Craig Allen Nard, Legal Forms and the Common Law of Patents, 90 B.U. L. REV. 51, 57 (2010) (discussing "captureprone administrative rulemaking").

429. See Dan L. Burk \& Mark A. Lemley, The Patent Crisis and How the Courts CAN Solve IT 100 (U. of Chi. Press 2009) ("Technology-specific patent legislation encourages rent-seeking"); Robert P. Merges, As Many as Six Impossible Patents Before Breakfast: Property Rights for Business Concepts and Patent System Reform, 14 BERKELEY TECH. L.J. 577, 592 (1999) (explaining that an indirect cost of issuing invalid patent includes rent-seekers who take advantage of the relaxed patent standards); Carl Shapiro, Patent System Reform: Economic Analysis and Critique, 19 BERKELEY TECH. L.J. 1017, 1022-23 (2004) (showing the problems created by patent monopolies and how competition authorities are addressing them); John R. Thomas, The Responsibility of the Rulemaker: Comparative Approaches to Patent Administration Reform, 17 BERKELEY TECH. L.J. 727, 731 (2002) (reasoning that the USPTO is a target for "rent-seeking entrepreneurs" who want to form patent acquisition ventures). 
The most direct example of this sector-specific politicization in ex post exercises of the patent validity power is covered business method review under the AIA. ${ }^{430}$ Structurally, CBM proceedings follow the standards and procedures of post-grant review. ${ }^{431}$ In application, meanwhile, CBM reviews allow the invalidation even of patents issued prior to the AIA, just as inter partes reviews allow. ${ }^{432}$ What distinguishes covered business method review from other AIA proceedings, however, is its emphasis on a particular industry sector:

[T] he term "covered business method patent" means a patent that claims a method or corresponding apparatus for performing data processing or other operations used in the practice, administration, or management of a financial product or service, except that the term does not include patents for technological inventions. ${ }^{433}$

The statute also calls for this definition to be elaborated through agency regulation. ${ }^{434}$ The result is still greater political, rather than adjudicatory, valence to the Patent Office's ex post power over patent validity.

\section{Commingled Powers in the Patent Office}

The agency's power over patent validity is divided into two tasks-screening PTAB petitions for apparent merit and adjudicating selected petitions-and these tasks rest with the agency's political leadership and adjudicatory apparatus, respectively. ${ }^{435}$ This alone might be cause for concern, as it

430. See Leahy-Smith America Invents Act, Pub. L. No. $112-29 \S 18,125$ Stat. 284, 329-31 (2011) (discussing the transitional program for covered business method patents).

431. See id. $\S 18(a)(1)$ (describing how the transitional program shall employ the standards and procedures of post-grant review).

432. See id. $\S 18(\mathrm{a})(2)$ (explaining how the regulations of this subsection apply to any covered business method patents issued before the Act).

433. Id. § 18(d)(1) (emphasis added).

434. See id. §18(d)(2) (clarifying that the Director can issue regulations for determining whether a patent is for a technological invention).

435. See supra notes 404-410 and accompanying text (listing the screening criteria for inter partes review, covered business method review, and post-grant 
interposes a political filter at the threshold of an adjudicatory process traditionally justified in terms of agency expertise. ${ }^{436}$ For better or worse, however, this has been the pattern of ex post patent validity review in the Patent Office from the start. ${ }^{437}$

What is cause for greater concern is that the screening and adjudicating functions in modern AIA review are currently commingled in the same entity within the agency: the PTAB. ${ }^{438}$ That commingling is likely unauthorized under the law. ${ }^{439}$ It has also produced undesirable incentives for the Patent Office to evade judicial review, incentives that the agency has pursued in progressively broader, more far-reaching arguments. ${ }^{440}$

Although the AIA delegates to the Director the power to screen petitions for inter partes review, covered business method review, and post-grant review, ${ }^{441}$ the Director does not personally exercise this power. ${ }^{442}$ Instead, the Director has subdelegated this power to the Patent Trial and Appeal Board.443 The AIA also delegates to the PTAB the power to adjudicate, and this

review under the AIA).

436. See Strategic Decision Making, supra note 8, at 55-56 (discussing the reasons to favor administrative review of post-patent proceedings over Article III review).

437. Both ex parte and inter partes reexamination, for example, placed initial screening of petitions seeking administrative review within the power of the Director and, prior to that, the Commissioner for Patents. See 35 U.S.C. $\S 303$ (1980) (providing that the Director will determine new questions of patentability within three months following a request for reexamination); see also id. $\S 312$ (1999) (listing the requirements for a petition under section 311).

438. See Porous Court-Agency Border, supra note 114, at 1078 (stating that the Director has the authority to sub-delegate screening power to the PTAB and to conduct the actual review).

439. See id. (claiming that Patent Office adjudication is politically distorted due to the authority delegated to the politically appointed Director of the Patent Office to screen requests for review).

440. See supra Parts I.B-I.D (outlining the different approaches taken by the Patent Office to avoid judicial review).

441. See 35 U.S.C. $\S \S 314(a), 324(a)$ (2012) (discussing the authority of the Director in instituting inter partes review and post-grant review).

442. See Porous Court-Agency Border, supra note 114, at 1078 (acknowledging that the Director sub-delegates the screening power to a three-judge panel in the PTAB).

443. See 37 C.F.R. $§ 42.4$ (a) (2012) ("The Board institutes the trial on behalf of the Director."). 
delegation is direct. ${ }^{44}$ In current practice, the panel of three administrative patent judges who screen a petition for sufficiency are the same panel who adjudicate the petition if it is accepted for review. ${ }^{445}$

However, it is doubtful that the Director has authority to subdelegate the screening function to the PTAB in this way. ${ }^{446}$ The ability of the Director to subdelegate his powers extends to subordinates whom the Director has himself appointed. ${ }^{447}$ The Director may "appoint . . . officers, employees (including attorneys), and agents" 448 and may "define the ... authority ... of such officers and employees and delegate to them such of the powers vested in the Office." 449 These constraints matter because the Director may not act outside any "specific limitation on [his] delegation authority." 450

The administrative patent judges of the PTAB are not within the reach of this delegation authority because the Director does not appoint judges to the PTAB. ${ }^{451}$ That power rests with the

444. See 35 U.S.C. $\S 318$ (a) (delegating to "the Patent Trial and Appeal Board" the authority and obligation to issue final written decisions in inter partes reviews); see also id. $\$ 328$ (a) (discussing the authority of the "Patent Trial and Appeal Board" to issue final written decisions in post-grant reviews and, by extension, covered business method reviews).

445. See Ethicon Endo-Surgery, Inc. v. Covidien LP, 812 F.3d 1023, 1028 (Fed. Cir. 2016) (explaining that the Patent Office "has determined that, in the interest of efficiency, the decision to institute and the final decision should be made by the same Board panel").

446. This argument was advanced by the appellant in Ethicon $v$. Covidien, and the discussion here tracks substantially that argument. See Brief for Intervenor-Director of the USPTO, Ethicon Endo-Surgery, Inc. v. Covidien LP, 812 F.3d 1023 (Fed. Cir. 2016) (No. 2014-1771), 2015 WL 1523016, at *29 (arguing that the statutory limits prohibit the Director from delegating the institution decision to the PTAB).

447. See 35 U.S.C. $\S 3(\mathrm{~b})(3)$ (describing the authority of the Director to appoint officers, employees, and agents and to define their duties).

448. $\quad I d . \S 3(\mathrm{~b})(3)(\mathrm{A})$.

449. Id. § 3(b)(3)(B) (emphasis added).

450. Touby v. United States, 500 U.S. 160, 169 (1991).

451. See Pub. L. No. 110-313, § 1(a), 122 Stat. 3014, 3014-15 (2008) (amending 35 U.S.C. $\S 6$ to provide that the Secretary of Commerce, in consultation with the Director of the PTO shall appoint administrative patent judges). 
Secretary of Commerce.452 In fact, the power to appoint PTAB judges must rest with the Secretary of Commerce for their authority to be constitutionally legitimate under the Appointments Clause. ${ }^{453}$ Starting in 2000, the Director did have authority to appoint judges to the Board ${ }^{454}$ in an effort to enhance his oversight of agency affairs and to give the agency more autonomy and operational freedom. ${ }^{455}$ However, it became clear by 2008 that this authorization was impermissible. ${ }^{456}$ Accordingly, Congress revised the statute to its current form, authorizing "the Secretary of Commerce, in consultation with the Director," to appoint Board judges ${ }^{457}$ and fix the constitutional defect. ${ }^{458}$ Thus, the problem of subdelegating the Director's screening function to the PTAB may be intractable. The Director

452. See 35 U.S.C. $§ 6(a)$ (2012) ("The administrative patent judges shall be ... appointed by the Secretary").

453. See generally John F. Duffy, Are Administrative Patent Judges Unconstitutional?, 77 GEO. WASH. L. REV. 904 (2009).

454. See Consolidated Appropriations Act, Pub. L. No. 106-113, § 4717, 113 Stat. 1501 (1999) ("The administrative patent judges shall be . . . appointed by the Director.").

455. See 154 Cong. REC. H7234 (2008) (statement of Rep. Steve King) ("[I]nventors, trademark owners, and Members of Congress believed the agency would function more efficiently if it were allowed greater operational freedom.").

456. See id. at H7233-35 (statements of Reps. Steve Cohen and Steve King) (claiming that the authority to appoint administrative law judges should be given to the Secretary of Commerce to be consistent with the Constitution).

457. See Pub. L. No. 110-313, § 1(a), 122 Stat. 3014, 3014-15 (2008) (delegating the authority to appoint administrative patent judges and administrative trademark judges to the Secretary of Commerce).

458. The revision certainly solved the matter prospectively: future cases decided by the Board would not be vulnerable to challenges based on their issuance by improperly appointed judges. See Duffy, supra note 453, at 919 (discussing how the 2008 appointment structure of administrative patent judges has solved the constitutional problem of the previous appointment structure). However, the statute also purported to make the change retroactive in two ways. One was to authorize the Secretary of Commerce to deem the appointment of a Director-appointed judge to "take effect on the date" of the initial appointment. Pub. L. No. 110-313, § 1(c), 122 Stat 3014 (2008). The other was to establish the "de facto officer" doctrine as a defense to any challenge against a Director-appointed judge. $I d . \S 1(\mathrm{~d})$. Neither of these is necessarily a "constitutionally rigorous solution" to the problem of retroactivity. Duffy, supra note 453 , at 920 . Interest in the subject appears to have died down since the Supreme Court denied certiorari in the leading active challenge to the Patent Office's prior practice. See generally Translogic Tech., Inc. v. Dudas, 555 U.S. 813 (2008). 
cannot define the powers of PTAB judges unless he appoints them, and he cannot constitutionally appoint them. ${ }^{459}$

This is not to say, of course, that the Director cannot assign to anyone else the screening of petitions for post-issuance review under the AIA. The sheer volume of petitions runs into over a thousand per year, ${ }^{460}$ and it would be infeasible and absurd to forbid sub-delegation altogether. The question is, among those whom the Director can properly appoint, who can properly carry out the screening function in the Director's place?

One sensible solution is to differentiate those who can screen from those who can adjudicate based on the Appointments Clause jurisprudence itself. ${ }^{461}$ What makes it necessary for the Secretary of Commerce to appoint PTAB judges is that they are "inferior Officers - who perform significant functions pursuant to law and who are subject to the Appointments Clause" rather than "mere employees, who are lesser functionaries lacking substantial powers." 462 The offices of PTAB judges are "established by Law and they perform more than ministerial tasks"-tasks in which they exercise "significant discretion." 463

By contrast, the category of employees who would screen petitions need not exercise the same high level of discretion as PTAB judges. Their offices are not "established by law" nor their duties "delineated in a statute." 464 Instead, they could be constituted merely by internal agency action in the way that $\S 3(b)(3)$ envisions for the Director. 465 They would not "take

459. See supra note 457 and accompanying text (showing that the power to appoint PTAB judges is delegated to the Secretary of Commerce).

460. Unted States Patent and Trademark Office, Patent Trial and APPEAL BOARD STATISTICS 3 (2017), https://perma.cc/7TRU-ZPMM (PDF).

461. See Duffy, supra note 453, at 906 (claiming that "administrative patent judges exercise significant authority within the meaning of the Supreme Court's Appointments Clause jurisprudence.").

462. See id. (discussing Freytag v. Comm'r, 501 U.S. 868 (1991) and the distinction between inferior Officers who are subject to the Appointments Clause and employees).

463. Id. (citing Freytag v. Comm'r, 501 U.S. 868, 881-82 (1991)) (internal quotations omitted).

464. Freytag v. Comm'r, 501 U.S. 868, 881 (1991).

465. See 35 U.S.C. $\S 3(\mathrm{~b})(3)$ (2012) (stating that the Director has authority over officer, employees, and agents of the Office "necessary to carry out the 
testimony, conduct trials, rule on the admissibility of evidence, and have the power to enforce compliance with discovery orders," as PTAB judges can do-indeed, must do. 466

Instead, screening petitions for further review, though not trivial, would be well within the competency of an agency employee who has ordinary, examiner-level technical expertise and ordinary, attorney-level legal training. ${ }^{467}$ Notably, the authority of the Director to appoint employees and define their duties, including by sub-delegation, expressly includes employees who are attorneys. ${ }^{468}$ Thus, although the commingling in the PTAB of the screening and adjudicating functions is unlawful, it is readily remediable under existing agency authority.

In addition to being improper as a formal matter, commingling these functions is also improper for functional reasons. Empowering the PTAB, especially the same three-judge panel of PTAB judges, to screen petitions and then to adjudicate them obscures whether, and to what extent, judicial review is available for the PTAB's actions. The outcome of the screening process is "final and nonappealable," as has been the case in every mechanism for administrative validity review that Congress has ever established. ${ }^{469}$ By contrast, the subsequent adjudication both is subject to judicial review by statute 470 and would be subject to judicial oversight under the Administrative

functions of the Office").

466. Freytag, 501 U.S. at 881-82.

467. See United States Patent AND TRADEMark OfFICE, OfFice of ENROLLMENT AND DISCIPLINE, GENERAL REQUIREMENTS BULLETIN FOR ADMISSION to the Examination for Registration to Practice in Patent Cases before the UnITED STATES PATENT AND TRADEMARK OFFICE 2 (2019) https://perma.cc/RH8F-QEXA (PDF) (stating that the requirements for registration include "legal, scientific, and technical qualifications necessary ... to render applicants valuable service").

468. See 35 U.S.C. $\S 3(b)(3)(A)$ "The Director shall appoint such officers, employees (including attorneys), and agents of the Office as the Director considers necessary ....") (emphasis added).

469. See supra notes 414-416 and accompanying text (explaining how the Director's screening decision in administrative validity review is nonappealable).

470. See 35 U.S.C. $§ 329$ (stating that dissatisfied parties may appeal decisions of the Patent Trial and Appeal Board). 
Procedure Act even in the absence of a statute expressly authorizing review. ${ }^{471}$ The presumption is in favor of review. ${ }^{472}$

In fact, the scope of nonappealability is even broader for screening in AIA proceedings. Decisions to deny petitions are immune from judicial oversight, and so are decisions to accept petitions. ${ }^{473}$ In reexamination, only decisions to deny were immune, ${ }^{474}$ leaving decisions to proceed subject to ordinary judicial review. 475

As a result, commingling the screening and adjudicating functions is a greater concern in the context of inter partes review, covered business method review, and post-grant review than it was for the reexamination mechanisms. Faulty decisions to accept petitions cannot be corrected at all by the courts. ${ }^{476}$ Classifying issues as screening-related or adjudication-related is necessary for determining the availability of judicial review. ${ }^{477}$ There is an incentive, therefore, for the Patent Office to conflate screening with merits adjudication both to enlarge the domain of its influence and action and to insulate itself from judicial review.

471. See 5 U.S.C. $\S 702$ ("A person suffering legal wrong because of agency action . . . is entitled to judicial review thereof.").

472. See Cuozzo Speed Techs., LLC v. Lee, 136 S. Ct. 2131, 2140 (2016) (recognizing the presumption in favor of judicial review in interpreting statutes).

473. See 35 U.S.C. $\$ 314$ (d) (immunizing the "determination by the Director whether to institute" regarding inter partes review) (emphasis added); see also 35 U.S.C. $\$ 324(\mathrm{e})$ (immunizing the "determination by the Director whether to institute" regarding post-grant review) (emphasis added).

474. See 35 U.S.C. $\S 303$ (c) (1980) (immunizing the "determination by the Director ... that no substantial new question of patentability has been raised") (emphasis added); 35 U.S.C. $\S 303(\mathrm{c})$ (2000) (same); 35 U.S.C. $\S 303(\mathrm{c})$ (2002) (same); 35 U.S.C. § 303(c) (2012) (same); 35 U.S.C. § 312(c) (1999) (same); 35 U.S.C. $\$ 312$ (c) (2002) (same); 35 U.S.C. § 312(c) (2011) (same).

475. See, e.g., In re Swanson, 540 F.3d 1368, 1375 (Fed. Cir. 2008) (finding appellate jurisdiction to opine on the contours of the "substantial new question of patentability" requirement).

476. See supra note $\mathbf{4 7 3}$ and accompanying text (stating that determinations by the Director not to institute review are not subject to appeal).

477. Compare 35 U.S.C. $\S \S 319,329$ (2012) (stating that a party may appeal the final decision of the PTAB in inter partes review and post-grant proceedings), with supra note 474 (explaining that the decision to institute review by the Director is nonappealable). 


\section{Focal Points for Reform}

As Parts II and III showed, panel stacking and the push for increasingly unreviewable discretion are symptoms of the recent tendency of the Patent Office toward aggrandizing its own power. As Part IV thus far has explained, the etiology has been the agency's commingling of separately delegated powers-one reviewable, the other nonreviewable -against a backdrop of greater political input into the patent system. From this, there emerges three simple focal points for reform.

First, the Federal Circuit should take an appropriate opportunity to interrogate the practice of panel stacking. The court's scrutiny should include briefing on the due process issues that were left unresolved in Alappat and have remained open ever since. ${ }^{478}$ For its part, the Patent Office has continued to rely on the outcome of that case as the basis for its use of panel stacking, ${ }^{479}$ and even this justification has been overborne by intervening changes in the structure of administrative patent review. ${ }^{480}$

It should also include briefing on the ability of the Director of the Patent Office to take his screening power to determine whether PTAB petitions are likely enough to prevail that review is warranted ${ }^{481}$ and subdelegate that power to administrative patent judges, whom he is not constitutionally empowered to appoint or whose duties he is not statutorily empowered to define. ${ }^{482}$

Second, the Federal Circuit should continue to view with skepticism the expansive interpretation of important, but relatively narrow provisions for nonappealability in PTAB

478. See supra notes 255-261 and accompanying text (comparing the facts of In re Alappat, 33 F.3d 1526 (Fed. Cir. 1994) to the current structure of the PTAB).

479. See supra note 42 and accompanying text (showing that the Patent Office still believes Alappat holds and relies on that case in oral argument before the Federal Circuit)).

480. See supra notes $262-270$ and accompanying text (highlighting the need to maintain the decisional independence of the PTAB judges).

481. See 35 U.S.C. $\S \S 314,324$ (stating the authority of the Director to authorize inter partes review and post-grant review).

482. See supra notes $446-458$ and accompanying text (explaining that the Director is no longer empowered to appoint administrative patent judges). 
review. Despite an early victory before the Federal Circuit in St. Jude and Achates ${ }^{483}$ and before the Supreme Court in Cuozzo, ${ }^{484}$ the Patent Office seems to have reached a retrenchment in its autonomy from judicial supervision. The en banc Federal Circuit in Wi-Fi One ${ }^{485}$ and the Supreme Court in SAS Institute ${ }^{486}$ rejected the most recent and most far-reaching claims of unreviewable agency discretion. It is the application of these latter precedents as refinements of the initial cases that hold the greatest promise for vindicating the robust presumption in favor of judicial review over agency action, and for preserving the ability of the Federal Circuit to police not only current Patent Office excesses, but future excesses as well. ${ }^{487}$

Third, the Federal Circuit, in a case that properly presents the issue, should revisit the current Patent Office structure that commingles the Director's screening powers with the PTAB's adjudication powers. These powers are separately delegated in the organic statute that establishes administrative patent revocation, and the differences between them are significant. ${ }^{488}$ One entrusts discretion to a political agency head in order to enable initial judgments about allocating scarce agency resources without immediate judicial intrusion. The other requires adjudication that is both based on neutral, generally applicable legal principles and legitimized by meaningful judicial review. To commingle these powers in the same entity within the Patent Office obscures their distinct purposes and enables the very pattern of aggrandizement that the agency has undertaken. The Federal Circuit in Ethicon declined an opportunity to address the merits of these issues both in its panel decision and in its denial

483. See supra Part III.A.2 (discussing the impact of the nonappealability of PTAB decisions).

484. See supra Part II.B (explaining the potential limits of the unreviewable discretion of the Patent Office).

485. See supra Part II.C (illustrating statutory limits on the Patent Office to reevaluate patent validity).

486. See supra Part II.D (discussing the Patent Office's conflation of the power to screen petitions with the power to adjudicate).

487. See supra Part III.B.4 (reasoning that the inability to review PTAB decisions leads to a lack of judicial scrutiny by the Federal Circuit).

488. See 35 U.S.C. $\S \S 311(b), 321(b)$ (2012) (granting the Patent Office the authority to "cancel as unpatentable 1 or more claims of a patent"). 
of en banc rehearing, ${ }^{489}$ though Judge Newman's dissents in both instances offer a valuable roadmap for redoubling the effort to seek en banc review in the future. ${ }^{490}$

\section{Conclusion}

Much of the Patent Office's recent political aggrandizement is a result of conflating large portions of its ordinarily reviewable adjudicatory process with the initial unreviewable screening process that it also happens to administer. ${ }^{491}$ The sustained campaign of the agency to conduct patent validity reviews outside the reach of judicial review is at the heart of the leading systemic controversies in patent law today. The conflation of the agency's power to screen petitions with its power to adjudicate them has also brought with it a new opacity in how the agency reaches its decisions. Of particular concern are the stacking of adjudicatory panels until a majority emerges that can deliver politically palatable judgments 492 and the push to expand ordinary nonappealability provisions to cover a wide range of adjudicatory activities over which the Federal Circuit would routinely exercise review. 493

Only six years have passed since the AIA's post-grant trial proceedings went into effect. The relatively early stage at which these decisions have come, therefore, make this an important moment in the evolution of patent law's power. Ignoring these problematic agency practices and allowing their underlying cause to persist would reinforce an already troubling status quo.

489. See Ethicon Endo-Surgery, Inc. v. Covidien LP, 812 F.3d 1023, 1033 ("There is nothing in the Constitution or the statute that precludes the same Board panel from making the decision to institute and then rendering the final decision."); see also Ethicon Endo-Surgery, Inc. v. Covidien LP, 826 F.3d 1366 (denying the en banc rehearing on the issue of the commingling screening power and adjudication).

490. See Ethicon, 812 F.3d at 1036 (Newman, J., dissenting) (arguing that assigning the same PTAB panel to both institute and conduct inter partes review is contrary to the statute, 35 U.S.C. $\S \S 314,316$ (2012)); Ethicon, 826 F.3d at 1368 (Newman, J., dissenting) (same).

491. See supra Part II.D.

492. See supra Part II.A.

493. See supra Part III.B.4. 
Rejecting these practices and correcting the source of their proliferation would do much to bring into focus the neglected, but powerful influence of political decision-making on the modern exercise of agency power over patent validity.

\section{Appendix: Figures}

\section{Figure 1. U.S. Patent Trials, 1945-2011}

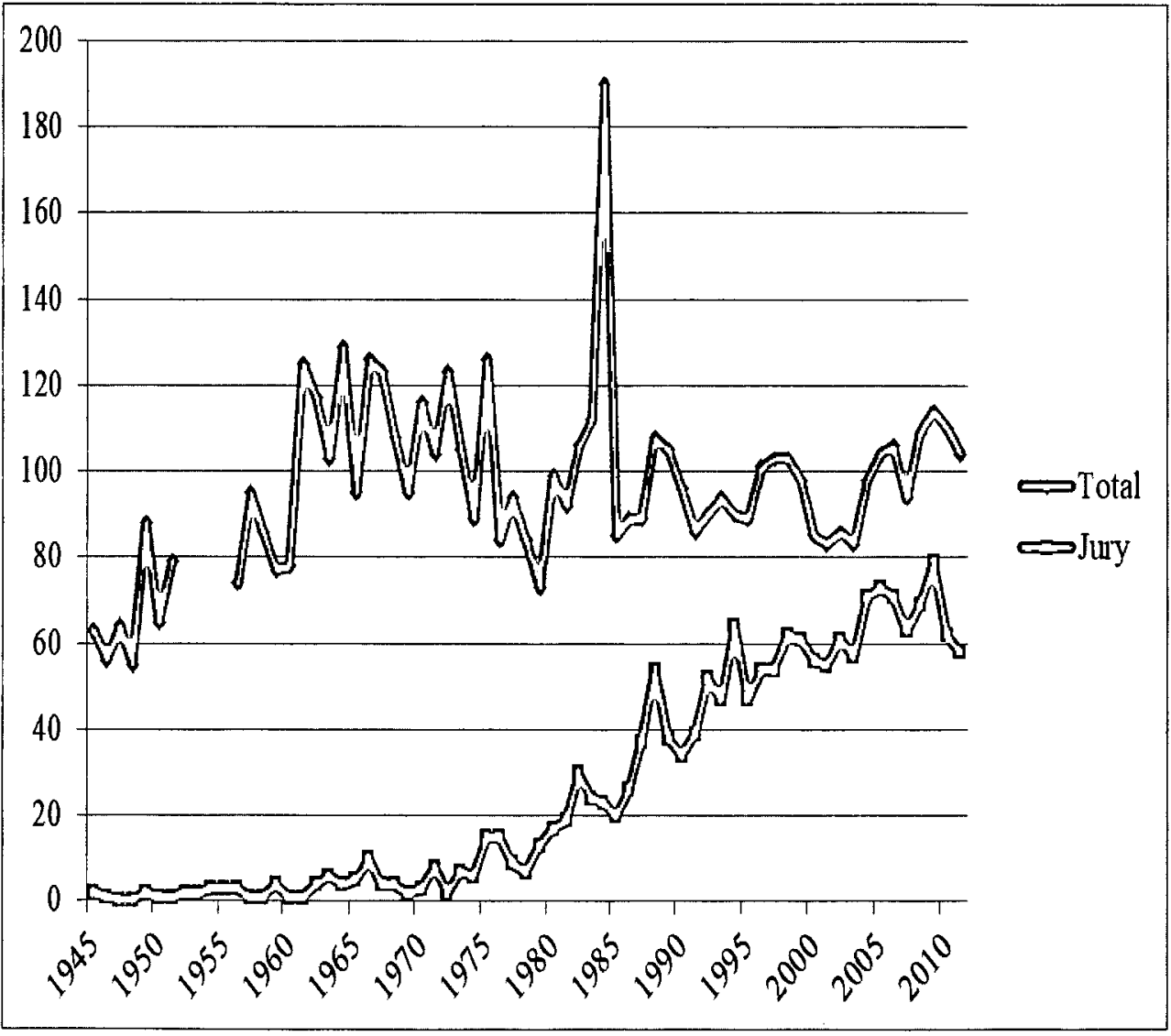

